\title{
Zonguldak Maden Teknisyen Mektebi (1940 - 1949)
}

\section{Zonguldak Mining Technician School (1940 - 1949)}

\author{
Emre Dölen ${ }^{1}$
}

1Prof. Dr., Marmara Üniversitesi Eczacılık Fakültesi Emekli Öğretim Üyesi, Istanbul, Türkiye

\section{ORCID: E.D. 0000-0002-3670-3627}

Sorumlu yazar/Corresponding author: Emre Dölen,

Marmara Üniversitesi Eczacılık Fakültesi, Istanbul, Türkiye

E-posta/E-mail: emredolen@gmail.com

Başvuru/Submitted: 06.10 .2020 Revizyon Talebi/Revision Requested: 03.11.2020

Son Revizyon/Last Revision Received: 12.11.2020

Kabul/Accepted: 13.11 .2020

Atıf/Citation: Dölen, Emre. "Zonguldak Maden Teknisyen Mektebi (1940-1949)." Osman/ı Bilimi Araștırmaları 22, 1 (2021): 1-66.

https://doi.org/10.26650/oba.806131

\section{öz}

Zonguldak'ta madencilik öğretimi 1924'de Zonguldak Maden Mühendis Mektebi'nin açılmasıyla başlamıştır. Bu okulun 1931'de kapatılmasının ardından 1949 yılına kadar geçen süre içinde Maden Tetkik ve Arama Enstitüsü (MTA) tarafından orta derecede madencilik teknisyenleri yetiştirmek üzere okullar açılmıştır. Bunlardan biri de 1940'da açılan ve ortaokul mezunlarını alan Zonguldak Maden Teknisyen Mektebi'dir. Bu okul 1949'da Milli Eğitim Bakanlığı'na devredilmiş ve kapatılarak yerine maden mühendisi yetiştiren Zonguldak Maden Teknik Okulu açılmıştır. Bu makalede Zonguldak Maden Teknisyen Mektebi'nin kuruluşu, yapısı ve 1940 - 1949 dönemindeki çalışmaları ele alınmıştır.

Anahtar sözcükler: Zonguldak, maden mühendisliği, maden teknisyenleri, Maden Teknisyen Mektebi

\section{ABSTRACT}

The provision of mining education in Zonguldak began in 1924 with the opening of the Mining Engineering School. After this school closed in 1931, mid-level schools for training mining technicians were established by the Institute of Mineral Research and Exploration (MTA). The Zonguldak Mining Technician School opened in 1940 and admitted secondary-school graduates. In 1949, this school came under the auspices of the Ministry of National Education and was then closed and replaced by the Zonguldak Mining Technical School, which trained mining engineers. In this article, the establishment, structure and activities of the Zonguldak Mining Technician School during 1940-1949 are discussed.

Keywords: Zonguldak, mining engineering, mining technicians, Mining Technician School 
Yirminci yüzyılın başlarında, Zonguldak kömür havzasında kömür üretimi hem devlet hem de yerli ve yabancı kişi veya şirketler tarafından yapılmaktadır. ${ }^{1}$ Havzada çok az sayıda yabancı maden mühendisi ve teknisyeni bulunmaktadır. Madenlerde çok kötü koşullar altında çalışan işçilerin tümüne yakını okuma yazma bile bilmemektedir. Bu durum hem üretim düşüklüğüne ve hem de kazalara neden olmaktadır.

Kurtuluş Savaşı sürerken konunun önemi nedeniyle 10 Eylül 1337 [1921]'de TBMM tarafından 151 sayılı "Ereğli Havza-yı Fahmiyesi maden amelesinin hukukuna müteallik kanun" kabul edilmiştir. ${ }^{2} \mathrm{Bu}$ kanun ile ilk kez, çalışan işçilerin barınma koşulları, çalışma saatleri, sosyal güvenceleri, sağlık hizmetleri ve ücretleri konusunda düzenlemeler getirilmiştir. Kanunun 13. maddesi ile "Maden ocağ âmilleri bir mescit ve genç ameleye gece dersleri vermek üzere bir mekteb yapmaya ve muallim tutmaya mecburdurlar" hükmü getirilmiştir. Burada hedeflenen, teknik öğretim olmayıp öncelikle işçilere okuma yazma öğretilip temel bilgilerin verilmesidir.

\section{Zonguldak’ta Madencilik Öğretiminin Başlaması (1924)}

Maden çavuşu ihtiyacını karşılamak üzere 1922'de 63 numaralı ocakta bir çavuş mektebi açılmıştır. Bir kurs niteliğinde olduğu anlaşılan bu girişim esaslı bir organizasyon ve parasal desteğin olmaması nedeniyle bir sonuç veremeden kapanmıştır. ${ }^{3} \mathrm{Bu}$ girişimden kısa bir süre sonra Havza-y1 Fahmiye Müdürü Hüseyin Fehmi [İmer; 1871 - 1960] Bey’in girişimi ile topograf, jeometr ve başçavuş yetiştirmek üzere bir Maden Fen Memuru Mektebi açılmasına girişilmiş ve bu okul 1924'de Maden Mühendis Mekteb-i Âlisi'ne dönüştürülmüştür. Okul 20 Ekim 1924'de törenle açılmış ve üç yıl olan öğretim süresi bir süre sonra dört yıla çıkartılmıştır. (Şekil 1). Okul Mehmed Refik [Fenmen; 1882 - 1951] Bey’in müdürlüğe atanmasının ardından çok büyük gelişme göstermiş ve ilk mezunlarını 1927 - 1928 ders yılı sonunda vermişstir. 1930'da maden mühendisliği yanında bir "Sanayi [Endüstri] Mühendisliği Şubesi” de açılmış ve okulun adı "Yükssek Maadin ve Sanayi Mühendisi Mektebi” olmuştur. Okul, dört dönemde 69 mezun verdikten sonra 1931 yılında mezuniyet sınavlarının ardından anlaşılamayan nedenlerle kapatılarak ilk üç sınıftaki öğrenciler İstanbul'daki Yüksek Mühendis Mektebi’ne devredilmiştir. ${ }^{4}$

1 İsa Tak, "Osmanlı Döneminde Ereğli Kömür Madenleri’nde Faaliyet Gösteren Şirketler," Atatürk Üniversitesi Türkiyat Araștırmaları Enstitüsü Dergisi 18 (2001): 253 - 257; Ekrem Murat Zaman, Zonguldak Kömür Havzasının İki Yüzyılı (Ankara: TMMOB Maden Mühendisleri Odası, 2004), 36 - 59.

2 Düstur, 3. Tertip, 2: 91; Mustafa Nuri Anıl ve Nejdet Merey, Türkiyede Maden Mevzuatı (İstanbul: 1942), 161 -163 .

3 "Maden Teknisyen ve Başçavuş okullarının çalışmalarına kısa bir bakış," Maden Tetkik ve Arama Dergisi 34 (1945), 308.

4 Emre Dölen, “Zonguldak Maden Mühendis Mekteb-i Âlisi (1924 - 1931)," Zonguldak Kent Tarihi 05 Bienali Bildiriler Kitabı (Zonguldak: Zonguldak Kültür ve Eğitim Vakfi, 2006) içinde, 21 - 31; Refik Fenmen yllar sonra 1954'de kapatılma konusunda “Zonguldak Yüksek Maadin ve Sanayi Mektebi bilmediğim bir sebebden [tarafımızdan italik yapılarak vurgulanmıştır] o zaman İktisat Vekili olan Merhum Mustafa Şeref'in 


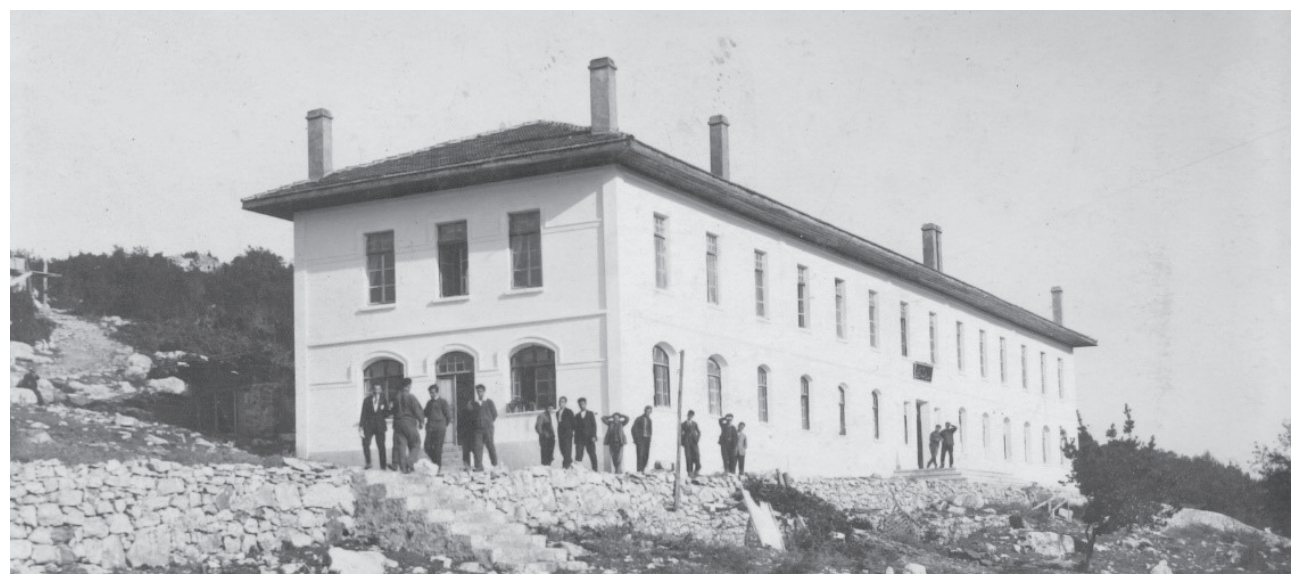

Şekil 1. Zonguldak Maden Mühendis Mekteb-i Âlisi’nin açıldığı yıllardaki ilk binası ve öğrenciler (Yazarın arşivi).

\section{Maden Meslek Şubesi/Mektebi (1930 - 1933)}

1930’da Yüksek Maadin ve Sanayi Mühendisi Mektebi’nde mühendislik öğretiminin yanında madenlere başçavuş yetiştirmeye yönelik olarak orta derecede ve iki yıllık bir "Maden Meslek Şubesi" açılmıştır. Refik Fenmen bu konuda aşağıdaki açıklamayı yapmaktadır:

Maden Meslek Şubesi'nin tesisi, madenlerde mühendis ile amele ve madenci çavuşları arasında çok faideli bir, mutavassıt olarak vazife gören başçavuş ve topograf yetiştirmenin de, madenlerimizin teşkilâtlandırılması bakımından ehemmiyeti aşikâr idi. Iş̧te bu teklifimiz de Vekâletce muvafik görülerek, orta derecede bir şube açılmış ve bu şubeye orta mektep mezunları alınmıştır. Madenci başçavuş şubesini bitirenlerin de, bir sene tahsil neticesinde topograf şahadetnamesi alabilmeleri mümkün idi. Bu şube mezunlarının pratik stajları daha fazla olması için, senede 5 ay ders, 5 ay madenlerde staj görmeleri kararlaştırılmıştı.

[Özkan; 1884 - 1938; Vekilliği 27 Eylül 1930 - 8 Eylül 1932] emrile maalesef 1931 senesinde kapatılmıştır”, diye yazmaktadır Bkz. Refik Fenmen, “Zonguldak Yüksek Maadin ve Sanayi Mektebi,” Isş 20, 159 (1954), 26. Okulun kapatılmasının arkasında yatan nedenler konusunda bilgi sahibi olduğu kuşkusuz olan Refik Fenmen'in olaydan 23 yıl sonra bile bu konuda bir açıklama yapmaması ilginçtir. Zonguldak'ta madencilik öğretimi ve özellikle Maden Mühendis Mektebi konusunda arşiv belgeleri bir yana konu ile ilgili basılı makale ve kitaplardan bile habersiz olup ikinci ve üçüncü el kaynakları kullanan bazı kişiler tarafından "hakemli" dergilerde makaleler yayınlanmaktadır. Örneğin, bir makalede var olan yığınla bilgiye karşılık Maden Mühendis Mektebi için "Okulun ders programına ve okutulan derslerin neler olduğuna dair bilgiler elde edilememiştir" diye yazılabilmektedir [Turgut İleri, "Cumhuriyet Döneminde Açılan İlk madencilik Okulları ve Madenci Yetiştirme Kursları,” The Journal of Academic Social Science Studies 5/6 (2012), 254].

5 Fenmen, “Zonguldak Yüksek,” 26. 


\section{Çizelge 1}

Maden Meslek Şubesi’nin İki Dönem Mezunlarının Adları ile 1931 - 1932 Dönemi Mezunlarının Çalıştıkları Yerler

(Zonguldak Sanayi ve Ticaret Odas1, Cumhuriyetin On Yılında Zonguldak ve Maden Kömürü Havzası, 1933, 144)

\begin{tabular}{|l|l|}
\hline \multicolumn{2}{|c|}{1931 - 1932 dönemi mezunları (14 kişi) } \\
\hline Adı & 1933'de çalıştı̆̆ yer \\
\hline Ali Sait Bey & Kozlu Türk Kömür Madenleri Şirketi'nde Başçavuş \\
\hline Fikret Ferit Bey & Fethiye madenlerinde Jeometr \\
\hline Fethi Barbaros Bey & Kartal Çimento Fabrikası'nda Başçavuş \\
\hline Fatih Selim Bey & Maden Kömürü İşleri Şirketi'nde Başçavuş \\
\hline Hakkı Hayrullah Bey & Kozlu Türk Kömür Madenleri Şirketi'nde Jeometr \\
\hline Hasan Muzaffer Bey & Kozlu Türk Kömür Madenleri Şirketi'nde Başçavuş \\
\hline İbrahim Hakkı Bey & Maden Kömürü İşleri Şirketi'nde Başçavuş \\
\hline Rasim Tevfik Bey & Maden Kömürü İşleri Şirketi'nde Başçuş̧ \\
\hline Ömer Orhan Bey & Kozlu Türk Kömür Madenleri Şirketi'nde Başçavuş \\
\hline Faruk Nafiz Bey & Kandilli Türk Kömür Madenleri Şirketi'nde Başçavuş \\
\hline Rasim İsmail Bey & Kartal Çimento Fabrikas'nda Başçavuş \\
\hline İbrahim Sami Bey & Kandilli ocaklarında Başçavuş \\
\hline İbrahim Şevket Bey & Maden Meslek Mektebi'nde Mutemet \\
\hline Zihni Bey & Kozlu Kömüriş Şirketi'nde Başçavuş \\
\hline \multicolumn{2}{|c|}{ 1932 - 1933 dönemi mezunu olup halen son beş aylık stajlarını yapmak } \\
üzere madenlerde çalışanlar (21 kişi)
\end{tabular}

Maden Meslek Şubesi için kısa bir Talimatname de hazırlanmıştır. ${ }^{6}$ [EK 1]. Talimatnamenin en önemli maddelerinden biri Mühendislik kısmında olduğu gibi "Mezunlar, hükümete mecburî hizmetle mükellef değildirler" hükmüdür (M. 8).

Okulda birici yıl Hesap [Aritmetik], Cebir, Hendese [Geometri], Müsellesat [Trigonometri], Kimya, Fizik, Mihanik [Mekanik], Resim [Teknik Resim], Jeoloji, Mineraloji, İşletme [Maden İşletmesi], Askerî Ders ve Fransızca dersleri ve ikinci yıl da Jeoloji, Resim, İşletme, Topografya, Sınaî Elektrik, Mihanik, Maden Kanunu, Hıfzıssıhha Askerî Ders ve Fransızca dersleri okutulmaktadır. ${ }^{7}$ Dersler Mühendislik Bölümü muallimlerinden Hendese

6 Yüksek Maadin ve Sanayi Mühendisi Mektebi Talebe Rehberi (İstanbul: T.C. İktisat Vekâleti, 1931), 90 - 91.

7 Yüksek Maadin ve Sanayi, 102 - 103. 
Muallimi Bedri Hüsnü [Bekiroğlu] Bey, Kimya Muallimi Mehmed Arif [Beylikçi] Bey, Jeoloji ve Mineraloji Muallimi Cemal Zühtü [Aysan] Bey, Hesap Muallimi Halil [Pekmen] Bey ve Maden İşletme Profesörü Guignard tarafından verilmektedir.

Bu okuldan 1931 - 1932 ders yılında 14 ve 1932 - 1933 ders yılında 21 olmak üzere 35 kişi mezun olmuş ve bunun ardından, havzada bu tür elemana büyük ihtiyaç olmasına rağmen bilinmeyen nedenlerle okul kapatılmıştır. ${ }^{8}$ Okulun iki dönem mezunlarının adları ile 1931 - 1932 dönemi mezunlarının çalıştıkları yerler Çizelge 1'de verilmiştir.

\section{Maden Tetkik ve Arama Enstitüsü (1935) ve Açılışı}

Maden aranmasına esas olmak üzere Türkiye'nin jeolojik açıdan incelenerek haritalarının yapılması konusundaki girişimlerin yavaş yürümesi üzerine daha kısa ve pratik yoldan sonuca ulaşmak için 20 Mayıs 1933'de kabul edilen 2189 sayılı kanun ile İktisat Vekâleti'ne bağlı olarak birbirinden bağımsız "Altın Arama ve İşletme İdaresi" ile "Petrol Arama ve İşletme İdaresi” kurulmuştur. ${ }^{9}$ Kurulan bu idareler önemli bir gelişim ve varlık gösterememiştir. Maden arama işlerinin bu tür kuruluşlarla yürütülemeyeceğinin kısa sürede anlaşılması üzerine 14 Haziran 1935 tarihinde kabul edilen 2804 sayılı kanun ile "Maden Tetkik ve Arama Enstitüsü” [M.T.A. Enstitüsü] kurulmuştur. ${ }^{10}$ Enstitü tüzel kişiliğe sahip olup bu kuruluş yasası ile özel hukuk kurallarına bağlıdır ve "ticarî usullere göre idare olunur. (M. 1). Enstitünün başlıca görevleri kanunun ikinci maddesinde aşağıdaki biçimde tanımlanmıştır.

Memleketimizde işletmeye elverişli maden ve taşocağı sahaları bulunup bulunmadığını ve işletilen maden ve taşocaklarının daha faydalı surette işletilmelerinin nelere mütevakkıf olduğunu araştırmak ve buna muktazi veya müteferri bulunan arama ameliyatı, fennî ve jeolojik tetkikat, kimyevî tahlil ve fennî tecrübeler yapmak, harita almak, plan mürtesem, maktalar resmetmek, proje ve fennî raporlar, rantabilite hesabları tanzim etmek gibi bütün teknik ve ilmî işleri görmek ve memleketin madenlerinde ve maden sanayiinde çalışacak Türk mühendis, fen memuru, ustabaşı ve mütahassıs işçi yetiştirmektir. ${ }^{11}$

Bu kanun ile 2189 sayılı kanun yürürlükten kaldırılarak Altın ve Petrol Arama ve İşletme İdareleri bütün hakları, borçları ve mevcutları ile estitüye devredilmiştir. M.T.A. Enstitüsü kuruluş kanununun geçici 3. maddesi ile "Zonguldak'ta bulunan tahlilhane ile mülga Maden Mektebi'nin mevcut gayrımenkulleri ile demirbaş eşya ve malzemesinden İktisat Vekâleti'nin tensib ettikleri M.T.A. Enstitüsü'ne meccanen verilir” hükmü getirilmiştir. Bu

8 Zonguldak Sanayi ve Ticaret Odas1, Cumhuriyetin On Yılında Zonguldak ve Maden Kömürü Havzası (1933), 143 - 144. Burada mezun sayısı 35 olarak görülmekle birlikte Refik Fenmen "Altmıştan fazla başçavuş ve topograf" yetiştiğinden söz etmektedir. [Fenmen, "Zonguldak Yüksek”, 26]. Bu ifade elimizde bir belge olmamakla birlikte okula 1933'den itibaren yeni öğrenci alınmayıp bu tarihte birinci sinıfta olanların öğrenimlerini sürdürerek 1934'de mezun olmuş olabileceklerini düşündürmektedir.

9 Resmî Gazete, Say1 2411 (27 Mayıs 1933), 2508.

10 Resmî Gazete, Sayı 3055 (22 Haziran 1935), 5378 - 5380.

11 İtalik yapılarak tarafımızdan vurgulanmıştır. 
hüküm uyarınca burada sayılanlar M.T.A. Enstitüsü’ne devredilmiştir.

Görüldüğü gibi, madencilik alanında her düzeydeki eğitim ve öğretimin yürütülmesi, kuruluş kanunu ile M.T.A. Enstitüsü’ne verilmiştir. Bu görevi üstlenen Enstitü 1935 - 1950 döneminde bir yandan kendisi ve başka kurumlar adına maden mühendisliği eğitimi görmek üzere seçtiği öğrencileri yurt dışına gönderirken öte yandan da Zonguldak’ta orta düzeyde teknik eleman yetiştirmek üzere okullar açmıştır.

M.T.A. Enstitüsü kuruluş yasasında gelir kaynakları sıralanırken (M. 11/e) ilginç bir uygulama getirilerek madencilik alanındaki eğitime kaynak yaratılmıştır. Buna göre,

e-Maden ve taşocakları işletenlerin istihdam eyledikleri ecnebi mühendis ve mütehassıslar mukabilinde Türk genci yetiştirmek üzere Hazineye yatıracakları Hazinece aynen Enstitüye tesviye edilecek ... e - fikrasında yazılı ücretler münhasıran Türk mühendis ve mütehassısları yetiştirmek hususlarına tahsis edilecek bu kısım varidatın ve ona tekabül eden masrafların hesabı ayrıca tutulacaktır.

\section{Zonguldak Maden Tatbikat Mektebi (1937-1940)}

Maden Tetkik ve Arama Enstitüsü'nün kuruluşundan k1sa bir süre sonra 1937'de Zonguldak havzasındaki ara eleman ihtiyacını karşılamak üzere "Zonguldak Maden Tatbikat Mektebi" açılmış ve bu okul için son derece ayrıntılı 53 maddelik bir talimatname hazırlanmıştır. ${ }^{12}$ İlkokul mezunlarının alındığı okul parasız ve yatılıdır. Okulun öğrenim süresi $2+1$ yıldır. Talimatnamenin 2/C maddesine göre, ${ }^{13}$

İkinci seneyi iyi ve çok iyi derece ile yani tam numara yekûnunun \% 70'inden fazla numara ile bitiren talebeler istek ve kabiliyetlerine göre Maden Jeometiri veya Ocak İçi İnşaat ve Tesisat Makineleri Ustası olarak yetiştirilmek üzere tahsillerine devam ederler. Tam numara yekûnunun \% 70'inden noksan ve \% 50'den fazla numara alan yani orta derece ile sinif geçen talebe ve iyi, çok iyi derece alıp da üçüncü sene tahsiline devam etmek istemeyen talebe. İşletme çavuşu olarak mezun olur.

12 Ekrem Murat Zaman, Kömürün Çocuklarl (Ankara: Karina Kitap, 2013), 129 - 131 ve 251 - 262. Okuldan günümüze kalan belgeler içinde iki tane talimatname bulunmaktadır. Bunlardan ikincisi daha sonra yapıldığı anlaşılan küçük değişiklikleri içermektedir. Ekrem Murat Zaman tarafından yayınlanmış olan talimatname bunların birincisidir.

13 Zaman, Kömürün Çocukları, 252. Geçmişte "Maden Meslek Şubesi”nde de benzer bir uygulamanın olduğu anlaşılmaktadır. [Fenmen, "Zonguldak Yüksek”, 26]. 

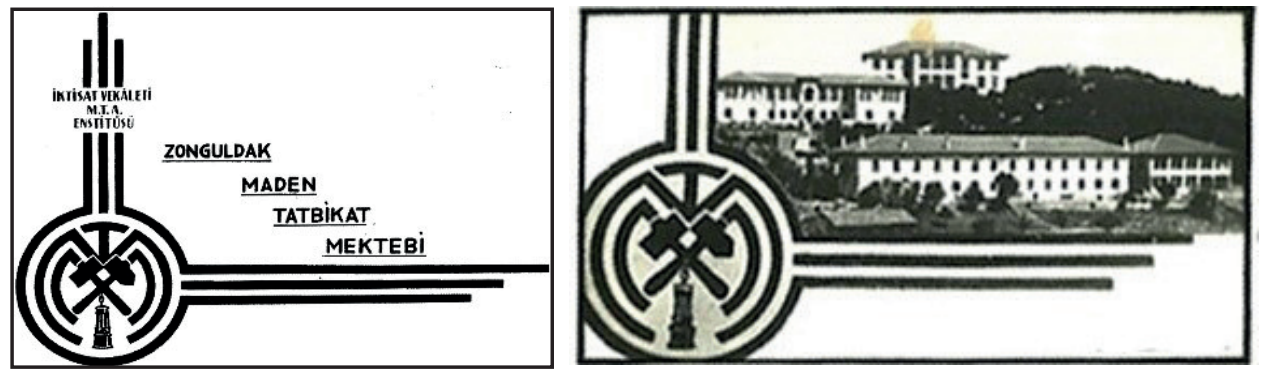

Şekil 2. Zonguldak Maden Tatbikat Mektebi'nin antet ve logosu (solda) ve küçük boyutlu bir bayram tebriki kartı (sağda) (Yazarın arşivi).

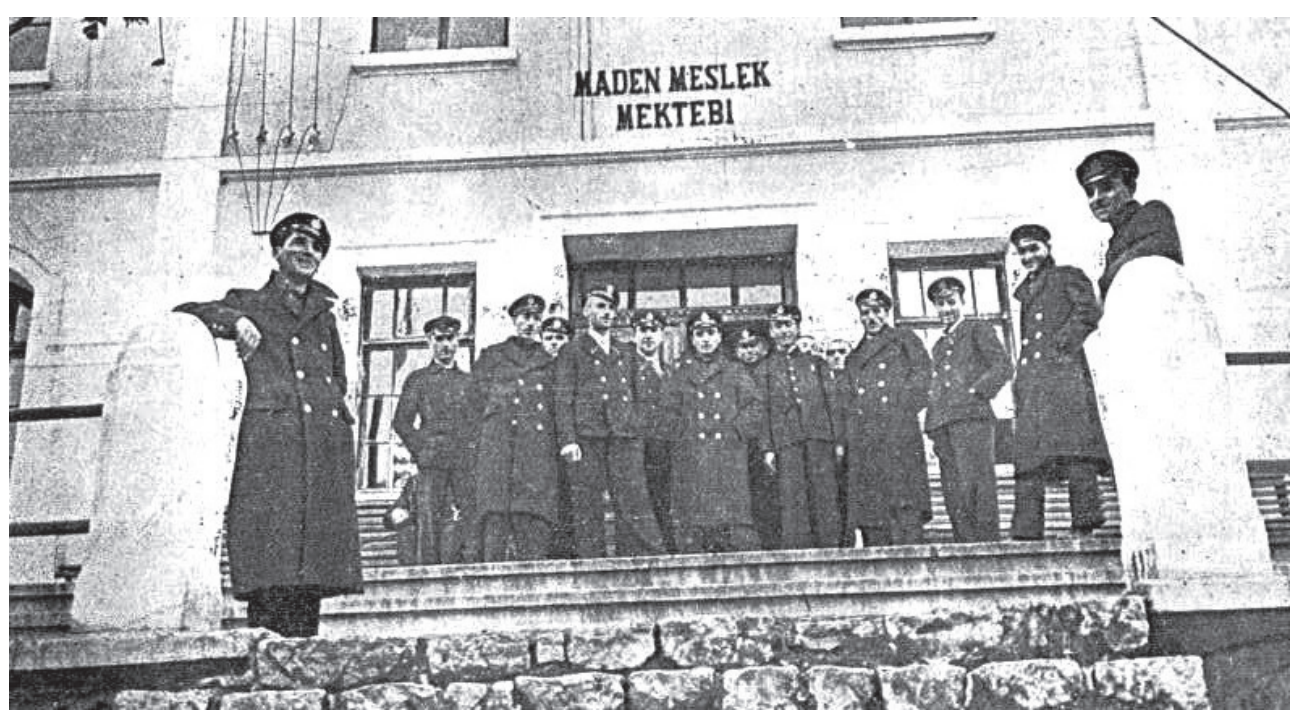

Şekil 3. Maden Tatbikat Mektebi öğrencilerinden bir grup 1937'de halen kapısında 1933'de kapatılan okulun adı yazılı olan okul binasının önünde (Yazarın arşivi).

Maden Tatbikat Mektebi ortaokul düzeyinde bir okul olup meslek dersleri yanında ortaokullarda okutulan temel dersler de okutulmaktadır. ${ }^{14}$ Maden Tatbikat Mektebi'nin ders programı (Çizelge 2)'de ve günlük zaman çizelgesi de [EK 2]'de verilmiştir. Bu okul yerleşip bir düzene girecek vakit bulamadan Maden Başçavuş Mektebi’ne dönüşmüştür.

$14 \mathrm{Bu}$ okul konusunda yakın dönemde bir makale yayınlanmıştır: Hasan Özer ve Kamuran Karabalık, "Yükseköğretim Tarihi İçerisinde Zonguldak Maden Tatbikat (Başçavuş) Mektebi (1937 - 1940)," Yüksekögretim ve Bilim Dergisi 7/2 (2017): 185 - 191. Burada ortaokul düzeyindeki bir meslek okulunun yükseköğretim ile olan ilişkisini anlamak mümkün olmadığı gibi birbirinin devamı olmakla birlikte yapı ve program açısından birbirinden farklı olan Maden Tatbikat Mektebi ile Maden Başçavuş Mektebi'ni birbirine karıştırılıp aynı okulmuş izleniminin yaratılması da yanlıştır. 


\section{Çizelge 2}

\section{Maden Tatbikat Mektebi’nin Ders Programı}

(Zonguldak Maden Tatbikat Mektebi Talimatnamesi, Madde 5)

\begin{tabular}{|c|c|c|}
\hline I. Sinif & II. Sinif & III. Sinif \\
\hline Türkçe [1] & Türkçe [1] & \multirow{20}{*}{$\begin{array}{l}\text { Maden jeometri ve } \\
\text { ocak içi inşaat, } \\
\text { tesisat usta } \\
\text { kısımlarını ihtiva } \\
\text { eden bu sınıfın } \\
\text { müfredat programı } \\
\text { tedris heyetincc } \\
\text { hazırlanır. Murakabe } \\
\text { heyetince tetkik } \\
\text { edilerek M.T.A. } \\
\text { Enstitüsü taarfından } \\
\text { tasvip ve tasdik } \\
\text { edildikten sonra } \\
\text { tatbik olunur. }\end{array}$} \\
\hline Yurt Bilgisi [1] & Yurt Bilgisi [1] & \\
\hline Tarih [1] & Tarih [1] & \\
\hline Coğrafya [1] & Coğrafya [1] & \\
\hline Askerlik [1] & Askerlik [1] & \\
\hline Hesap & Hesap & \\
\hline- & Cebir & \\
\hline Hendese & $\begin{array}{l}\text { Muhtasar Müsellesat ve } \\
\text { Hendese Tatbikatı }\end{array}$ & \\
\hline Resmihattî & Teknik Resim & \\
\hline $\begin{array}{l}\text { Maden İşletmesi } \\
\text { (Birinci kısım) }\end{array}$ & $\begin{array}{l}\text { Maden İşletmesi } \\
\text { (İkinci kısım) }\end{array}$ & \\
\hline $\begin{array}{l}\text { Jeoloji ve Madeniyat } \\
\text { (Birinci kısım) }\end{array}$ & $\begin{array}{l}\text { Jeoloji ve Madeniyat (İkinci } \\
\text { kısım) }\end{array}$ & \\
\hline $\begin{array}{l}\text { Madenlerde Kullanılan } \\
\text { Muharrik Kuvvet Esasları }\end{array}$ & $\begin{array}{l}\text { Ocaklarda Kullanılan } \\
\text { Makineler [2] }\end{array}$ & \\
\hline $\begin{array}{l}\text { Maden Kazaları ve Bunlara } \\
\text { Karşı Emniyet Tertibatı } \\
\text { (Birinci kısım) }\end{array}$ & $\begin{array}{l}\text { Maden Kazaları ve Bunlara } \\
\text { Karşı Emniyet Tertibatı } \\
\text { (İkinci kısım) [4] }\end{array}$ & \\
\hline Sağlık Bilgisi & $\begin{array}{l}\text { Sağlık Bilgisi ve Kazalarda } \\
\text { Alınacak İlk Sihhî Tedbirler }\end{array}$ & \\
\hline Basit Elektrik & - & \\
\hline Basit Teknoloji & - & \\
\hline $\begin{array}{l}\text { Ocak İçi İnşaat ve Tesisatı } \\
\text { (Birinci kısım) }\end{array}$ & $\begin{array}{l}\text { Ocak İçi İnşaat ve Tesisatı } \\
\text { (İkinci kısım) }\end{array}$ & \\
\hline Fizik (Birinci kısım) [3] & Fizik (İkinci kısım) [3] & \\
\hline Kimya (Birinci kısım) [3] & Kimya (İkinci kısım) [3] & \\
\hline- & Topografya ve Harita [5] & \\
\hline
\end{tabular}

[1] Orta Okul resmî müfredat programlarına göre.

[2] Bunların ayrı ayrı hususiyetleri, işletme tarzları, yekdiğerine nazaran faide ve mahzurları gösterilecektir.

[3] Bilhassa maden ocaklarını alâkadar eden hikemî ve kimyevî hadisat izah edilecek ve fizik dersi makine mevzularile beraber yürüyecektir..

[4] Maden ocaklarındaki faaliyette vazife ve mesuliyetin, doğruluk ve bağlılığın, disiplin ve inzibatın hayatî ehemmiyeti ve bunlarla alâkadar İş Kanunu, Maden Kanunu, havza amele birliği teşkilâtı4 ve mesleği alâkadar eden talimatname ve nizamnameler gösterilecektir.

[5] Bilhassa madenler nazarı itibara alınacaktır 


\section{Zonguldak Maden Başçavuş Mektebi (1941 - 1949)}

1940 yılında Zonguldak’ta yeni bir okul kurulur: Maden Teknisyen Mektebi. Ertesi y1l, Maden Tatbikat Mektebi, bu yeni okula bağlı olarak, üç yıllık Zonguldak Maden Başçavuş Mektebi'ne dönüştürülür. Tatbikat Mektebi'nin ikinci sınıfını bitirenler de Başçavuş Mektebi'nin üçüncü sınıfının öğrencileri olmuştur. ${ }^{15}$ Artık bağımsız bir okul söz konusu olmadığından talimatnamedeki birçok maddenin gereği kalmamış ve bu okul için 15 maddelik yeni bir talimatname hazırlanmıştır. ${ }^{16}$ [EK 3]. Talimatnameye göre okul yönetim, muhasebe, tedrisat ve disiplin bakımından Maden Teknisyen Mektebi mevzuatına göre yönetilir. (M. 13). Maden Tatbikat Mektebi'nde uygulanan ve çavuş ile başçavuş yetiştiren $2+1$ sisteminden vazgeçilerek üç yılda doğrudan başçavuş yetiştiren bir sisteme geçilmiş ve üç yıllık yeni bir ders programı hazırlanmıştır. (Çizelge 3). Başlangıçta uygulanan bu sistemden bir süre sonra vazgeçilerek alınan öğrencilerin bir yıl (300 gün) madenlerde çalışarak staj yapmasından sonra iki yıl da teorik ve pratik öğrenim gördüğü bir sisteme geçilmiş olduğu anlaşılmaktadır. (Şekil 4).

Başçavuş Mektebi öğrencilerinin yapacakları stajlara büyük önem verilmiştir. Başçavuş Mektebi öğrencilerinin yapacakları stajlara ilişkin esaslar Ereğli Kömürleri İşletmesi tarafindan düzenlenerek 29 Temmuz 1944'de 512/158 numaralı servis notu ile Kandilli, Üzülmez, Kozlu, Kilimli ve Gelik bölgeleri başmühendisliklerine gönderilmiştir. Buna göre, Başçavuş Mektebi birinci sınıfına kabul edilen öğrenciler 300 gün staj yapacaklardır. Bu süre içinde öğrenciler yardımcı işçi olarak 90 gün ocak içinde damar ve taşlarda yapılan hazırlık çalışmalarında, 45 gün ocak içi onarım ve tahkimat işlerinde, 45 gün ocak içi taşıma işleri ile bunların düzenlenmesinde, 90 gün kömür damarlarında yapılan üretim işlerinde ve 30 gün de ocak dışındaki tesislerde çalışacaklardır. İkinci sınıfı bitiren öğrenciler de dört aylık staj süresinde kömür hazırlama ve üretim işleri ile çeşitli onarım ve tahkim işlerinde çalışacaklardır. ${ }^{17}$

15 "Elyevm mevcut Maden Tatbikat Kursları, Maden Başçavuş Mektebine kalbedilmiştir. Bu kursların son sınıfı Maden Başçavuş Mektebinin üçüncü sınıfını teşkil edecektir.” (M. 14).

16 Anıl ve Merey, Türkiyede Maden Mevzuatı 2: 28 - 30.

17 Zaman, Kömürün Çocukları, 133. 
Çizelge 3

Maden Başçavuş Mektebi Ders Programı

\begin{tabular}{|c|c|c|}
\hline I. Sinif & II. Sinif & III. Sinıf \\
\hline Türkçe & Türkçe & Türkçe \\
\hline Yurt Bilgisi & Yurt Bilgisi & - \\
\hline Tarih & Tarih & - \\
\hline Coğrafya & Coğrafya & - \\
\hline Tabiat Bilgisi & - & - \\
\hline Beden Terbiyesi & Beden Terbiyesi & Beden Terbiyesi \\
\hline Askerlik & Askerlik & Askerlik \\
\hline Hesap ve Hendese & $\begin{array}{l}\text { Hesap ve Hendese } \\
\text { Tatbikatı }\end{array}$ & $\begin{array}{l}\text { Cebir ve Riyaziye } \\
\text { Tatbikatı }\end{array}$ \\
\hline- & Fizik & Fizik \\
\hline- & Kimya & Kimya \\
\hline Resim & Teknik Resim & - \\
\hline $\begin{array}{l}\text { Sağlık Bilgisi ve Sihhi } \\
\text { Yardım }\end{array}$ & $\begin{array}{l}\text { Sağlık Bilgisi ve Sihhi } \\
\text { Yardım }\end{array}$ & - \\
\hline Maden İşletmesi & Maden İşletmesi & Maden İşletmesi \\
\hline Emniyet & Emniyet & Emniyet \\
\hline- & Teknoloji ve Atölye & Teknoloji ve Atölye \\
\hline- & - & Makine \\
\hline- & - & Topografya \\
\hline- & - & Jeoloji ve Mineraloji \\
\hline- & - & $\begin{array}{l}\text { Ocak İçi İnşaat ve } \\
\text { Tesisatı }\end{array}$ \\
\hline- & - & Meslek Terbiyesi \\
\hline- & - & Meslek Mevzuatı \\
\hline
\end{tabular}

Mezun sayısı konusunda M.T.A. Enstitüsü'nün kendi tarihçesinde Maden Meslek Mektebi ile Maden Başçavuş Mektebi ayrımı yapılmaksızın aşağıdaki sayılar verilmektedir: ${ }^{18}$

1948 yılı sonuna kadar Enstitümüze bağlı bulunup ta o tarihten itibaren Millî Eğitim Bakanlığına devredilmiş olan Zonguldak Maden Teknisyen Okulundan 64 maden çavuşu, 130 maden başçavuşu ve 226 maden teknisyeni mezun olmuş ve bunlar maden işlerimizde vazife almışlardır.

18 Maden Tetkik ve Arama Enstitüsü 15 Yıllık Faaliyeti (Ankara: Mayıs 1950), 70. 
Burada verilen sayılar Maden Teknisyen Mektebi evrakı arasında bulunan onaylı listelerdeki sayılar ile uyum içinde değildir. ${ }^{19} \mathrm{Bu}$ listelerden Maden Başçavuş Okulu'nun başarı oranının son derece düşük olduğu görülmektedir. Okulun açılışından kapanışına kadar geçen süre içinde 156 mezun verilmesine karşılık 253 kişi başarısızlık veya başka nedenlerle okulu bitiremeden ayrılmıştır. Bu durumda okulun başarı oranı \% 38 düzeyindedir. M.T.A. Enstitüsü ise ayrılanları karşılamak için gazetelere sürekli olarak "Talebe Alınacaktır" başlıklı ilânlar vermiştir. Okulun öğrenciler üzerinde itici bir etki yapmasının ve onların okuldan ayrılmalarının nedenlerinden biri olarak alınan öğrencilerin staj adı altında doğrudan ocaklara indirilerek 300 gün işçi gibi çalıştırılması olduğu söylenebilir.

\section{TALEBE ALINACAK}

\section{Maden Tetkik ve Arama Enstitüsï}

\section{Genel Direktörlüğ̈ünden :}

Zongraldak Maden Baş̧arus Otulunum aralik 1945 ayıdd başlyacak deviesi için secrme smav ile jatil ve parasiz talebe almacaktr.

Milili Eğitim Bakanliğinca ikinci dercede orta ihtisas okulu olarak kabul edflen bu Teknik Okulun, birinci senesi pratik, diger 牟 genesinin biri pratik, digerl teorik olmak izzere iliger sämestre ayrilmis ü senelik ögreaim silresit vardir.

Ag̣ağıda jazilı maddelere uygun belge verebllen istekIflerin en ges 27/ 11/1945 aksamin kadar dilekçelerile Zonguldak Maden Teknisyen Mekteb! Müdürlü̆güne başurmaları gereklldtr.

1 - Türk olmak,

2 - Doğruluk kAğgdı göstermel (1944 - 1945 ders grl mezunlanndan bu belge aranmaz.)

3 - Bulaşıc hastaliğ olmathak, sağlık durumu maden ockklarında pratik çalıģmağa uygun bulunmak (Sağllk muayenesi Zonguldakta gapilacaktır).

4 - Ikokulu bitirme diploma veya belgest göstermek,

5 - 18 yaşma girmiş ve 25 yaşıı geçmemiş bulummak,

6 - Nüfus eïzdans ve 12 aded vesika fotoğrafi vermek.

Istekliler 28/11/1945 de Zonguldak Maden Teknisyen Mektebinde itkokul derslerinden yazil sınava girecekler ve kazananlar sağtuk muayenesinden sonra pratik stajlarunt baslamak tuzere ocaklara dağtzlacaklardur.

(15281)

Şekil 4. Maden Baş̧̧avuş Okulu'na öğrenci alınmasına ilişkin olarak M.T.A. Enstitüsü tarafından verilmiş olan bir gazete ilânı ("Talebe Alınacak", Cumhuriyet, 23 Kasım 1945, 6).

M.T.A. Enstitüsü tarafından öğrenci alımı konusunda gazetelere verilen ilânlardan Maden Başçavuş Mektebi'nden ayrı olarak maden çavuşu yetiştirmek üzere Kozlu'da parasız ve yatılı olarak Maden Tatbikat Kursları açılmış olduğu anlaşılmaktadır. ${ }^{20}$ [EK 4]. Bu ilâna göre:

19 Ekrem Murat Zaman, mezun sayısını 115 olarak vermektedir. [Zaman, Kömürün Çocuklarl, 134 - 135].

20 “Talebe Alınacak," Cumhuriyet, 16 Eylül 1941, 4. 
Kurslarda tahsil her sene bir ayı nazarî, bir ayı amelî olmak ve münavebe ile devam etmek üzere iki senedir.

Kurslara ilk mektep mezunları alınmakta olup talebe birinci senenin nazarî ve amelî tahsil devrelerinde asgarî 100, ikinci senede asgarî 120 kuruş yevmiye alacak, mektebi bitirenler maden çavuşu unvanıyla en az 230 kuruş yevmiye ile işe başlattırılacaktır.

Başvuru adresi olarak Maden Teknisyen Mektebi Müdürlüğü gösterilmiştir. Öğrenci çekebilmek için öğrencilere dönemine göre yüksek bir yevmiye ödenmektedir. Öğretimin bir ay teorik ve bir ay uygulamalı biçimde dönüşümlü olarak yapılması da ilginçtir.

Maden Başçavuş Mektebi öğrecilerine talimatname uyarınca verilen giyecek ve çamaşırların listesinin bir örneği [Ek 5]'de verilmiştir.

Başçavuşlar, sendikal örgütlenmenin öncüsü olarak 1946 yılı sonlarında "Zonguldak Maden Başçavuşları Cemiyeti”ni kurmuşlardır. Cemiyet, 26 Haziran 1947’den itibaren "Sosyal ve ekonomik konulardan bahseden bir işçi gazetesi” alt başlı̆̆ını taşıyan ve ilk sendika gazetesi olarak nitelenen Vardiya adlı gazeteyi yayınlamaya başlamıştır. ${ }^{21}$

\section{Zonguldak Maden Teknisyen Mektebi (1940 - 1949)}

\section{Okulun kuruluşu ve amacı}

Ülkenin maden mühendisi ihtiyacı gerek yurtdışına öğrenime gönderilenler ve gerekse Zonguldak Yüksek Maden Mühendis Mektebi'nden mezun olanlar yoluyla karşılanmaya çalışılmakta olup madenlerin gelişmesi ile birlikte maden teknisyeni ve başçavuş olarak eğitilmiş teknik eleman eksikliği de şiddetle hissedilmeye başlanmıştır. Bir teknisyen okulunun açılmasının daha 1938'de gündemde olduğu anlaşılmaktadır. Zonguldak Halkevi'nin 15. yıl kitabında halen bir amele çavuş mektebinin faaliyetde olduğu belirtilerek "Önümüzdeki yıllarda kalfa işçi ve diğer iş elemanlarını yetiştirmek üzere geniş bir teknik öğretim plânı tatbik olunacaktır” denilmektedir.22

Maden Teknisyen Mektebi'nin açılışından birkaç ay önce 8 Haziran 1940'da Zonguldak İktisat Müdürlüğü tarafından Ekonomi Bakanlığı'na gönderilen raporda aşağıdaki saptamalara yer verilmiştir: ${ }^{23}$

Kömür Havzamız işletmelerinin normal faaliyette ve mesai emniyetinde fennî nezaret işlerinin noksanlığı ve kifayetsizliği kuvvetle göze çarpmaktadır, işçilerimizin madenciliği meslek ittihaz etmemiş olmaları ile ayrıca bir ehemmiyet arzeden bu vaziyetin sür'atle islâh ve ikmâli daima inkişaf etmekte olan havzamız faaliyeti için bir zarureti katiye halinde

21 Zaman, Kömürün Çocukları, 220.

22 [Zonguldak Halkevi], Zonguldak 923 - 938 Cümhuriyet'in XV. inci Yıldönümü Hatırası (İstanbul: Tan Matbaas1, 1938), 95.

23 "Maden Teknisyen," 310. 
bulunmaktadır. Halen çalışan 940 kadar nezaret memur ve müstahdemlerinin mühim bir kısmı senelerin temin ettiği pratik malûmat ile biraz kabiliyet kazanmış ve bu mevkileri işgal etmiş olsalar da meslekî bir mektep veya kurs görmemeleri yüzünden ilmî ve esaslı ihtisasdan mahrum olarak işletmenin fennî ve idarî sevki işlerindeki kavrayışları mahdut bulunmaktadır.

Kömür havzamızdaki çalışan işçilerimizden mühim kısmının ayda bir değişmeleri ve bilhassa senelik mesailerinin vasati 4 ilâ 5 ayı geçmemesi yüzünden her sanayi şubesinden fazla dikkat ve ihtisas arayan maden işçilerinin normal faaliyeti ve mesai emniyeti üzerindeki tesirleri karşısında fennî nezaret ve idare kadromuzun her memleket madenciliğindeki nisbetten fazla ve mükemmel olması zarurî bulunmaktadır. Halbuki bu kadromuz halen normal vaziyete göre gerek adet ve gerek ihtisas bakımından zayıf olduğu kadar 2,5 milyon ton ilâve kömür esası üzerinden yürümesi lâzım gelen ihzarat ve istihsalâtımıza nazaran da bu vaziyet bir daha göze çarpacak bir ehemmiyette bulunmaktadır. Son yapılan yoklamaya göre mühendisler hariç olduğu halde dahilî oniki bin işçiye mukabil fennî nezaret ve idare müstahdemlerinin adedi 940 kadardır. 2,5 milyon ton ilâve istihsali faaliyetinde ise bu miktarın asgarî 1260 olması lâzım geldiği bittetkik anlaşılmıştır.

$\mathrm{Bu}$ raporda gösterilen ihtiyaç yalnız Zonguldak havzası için olup Türkiye'deki diğer madenlerde de aynı sıkıntı vardır.

Bu gelişmelerin sonucunda 13 Eylül 1940'da “Memleketimizde her gün biraz daha inkişaf etmekte olan maden işlerinde çalışması lüzumlu şahısların yetiştirilmesi maksadile ilişik esaslar dâhilinde Zonguldak'da bir maden teknisyen mektebi açılması"na ilişkin 2/14395 sayılı “Zonguldakta Maden Teknisyen Mektebi Açılması Hakkında Kararname" çıkartılmıştır. ${ }^{24}$ (Şekil 5 ve 6). Kararnamenin kurulacak okulun esaslarını belirleyen "Proje" başlıklı yedi maddelik ekine göre "Maden Tetkik ve Arama Enstitüsünce Zonguldakta bir maden teknisyen mektebi açılması tensib olunmuştur." (M. 1). Parasız yatılı olan okula ortaokul mezunları alınacaktır (M. 3). Okulun öğrenim süresi üç yıl olup buna ek olarak bir yıldan az olmamak üzere uygulama da içerecektir (M. 4). "Mektebi ikmal edenler maden teknisyeni unvanı ile İktisat Vekâletinin göstereceği mahallerde maden sanayii işlerinde beş sene müddetle çalışmağa" mecbur tutulacaktır (M. 6). "Mektep Maden Tetkik ve Arama Enstitüsü tarafından tanzim ve İktisat Vekâletince tasdik edilecek bir talimatname hükümleri dairesinde idare olunur" (M. 7). Buradaki esaslara dayanılarak M.T.A. Enstitüsü tarafından "Zonguldak Maden Teknisyen Mektebi Esas Talimatnamesi” hazırlanıp yürürlüğe konulmuştur. ${ }^{25}$ [EK 6]. Okul 1 Nisan 1941 tarihinde madenlerde staj görmüş 27 öğrenci ile öğretime başlamıştır.

Talimatnamede okulun amac1 "maden ocaklarında ve maden sanayii işletmelerinde çalışacak, nazarî ve amelî bilgilerle mücehhez teknisyenler” yetiştirmek olarak tanımlanmaktadır (M.1). Talimatnameye göre okulun yönetim ve örgütlenme şeması (Şekil 7)'de verilmiştir.

24 BCA, Fon kodu: 30.19.1.2/Yer No: 92.91.15; Resmî Gazete, Sayı 4623 (27 Eylül 1940), 14755 - 14756.

25 Anıl ve Merey, Türkiyede Maden, 2:19 - 27. Bundan sonraki madde numaraları bu talimatnameye göre verilmiştir. 


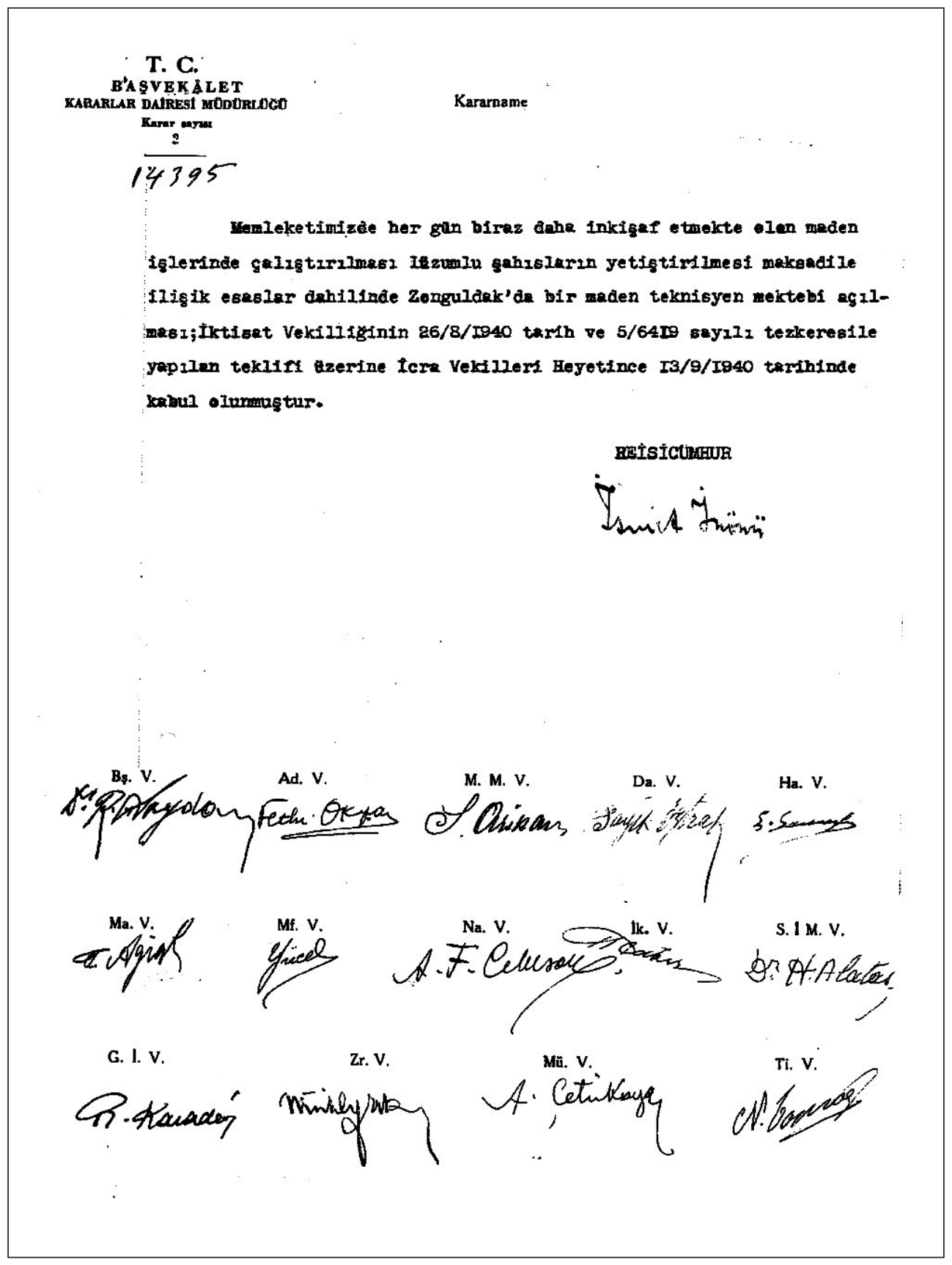

Şekil 5. 13 Eylül 1940 tarih ve 2/14395 say1lı “Zonguldakta Maden Teknisyen Mektebi Açılmas1 Hakkında Kararname” (BCA, Fon kodu: 30.19.1.2/Yer No: 92.91.15). 
Zonguldakte liaden Teknisyen liektebi 0 glmasi

hakkinda kararname

( proje)

jis doe - 1 : Waden Tetkik ve arama Enstitisiluce Zonguldakta bir Maden Teknisyen jektebi açl lmasi tensip olunmustur.

ifadde - 2 : liktep har sene lieden Tetkik ve Arama Enstititili bistģesinden tefrik olunacak tahsisatla idare olunur.

Wedde - 3: Wektebe orta derecede tahsil gormis olanlar al1ner. Her sene alınacak talebe sayıs Iktisat Vekí. letince tesbit olunur.

liedde -4 : hiektebin tahsıl milddeti liç senedir. Bunden başica bir seneden az olmamak tizere syruca tatbikst devresint de ihtivg eder.

btadde -5 : isktep nazars, yatzli ve meccanidir. Tatbikat devresinde talebe madenjerdeki kazanci ile gecinir.

iradde $-\sigma$ : jektebi ikmal edenler maden teknisyeni unvan ile

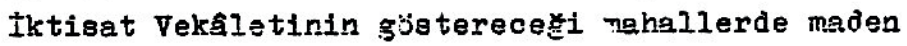

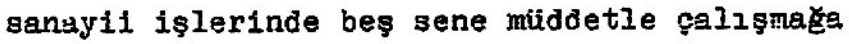
mecburdurlar.

Liadde -7 : Wektep iaden Tetkik ve Arama gnstitidsu tarafindan tanzim ve Iktisat Vekaletince tasdik edilecek bir talimatnane $h: k i j m]$ eri dairesinde idare olunur.

Şekil 6. 13 Eylül 1940 arih ve 2/14395 sayılı "Zonguldakta Maden Teknisyen Mektebi Açılması Hakkında Kararname"nin eki (BCA, Fon kodu: 30.19.1.2/Yer No: 92.91.15).

Okul uzman bir müdürün idaresine verilerek Esas Talimatnameye ve yapılacak diğer talimatnamelere göre yönetilir (M.11). Okul "tedris [öğretim] kısmı" ve "idare [yönetim] kısmı"olmak üzere iki kısımdan oluşmaktadır. Okulun öğretim kısmı Tedris Meclisi, muallim ve muavinler, laboratuvar ve atölye şefleri ve diğer teknik memur ve müstahdemlerden oluşur (M. 12). Okulun yönetim kısmı İdare Heyeti ve İnzibat Heyeti ile yönetim ve hesap işlerini yürütmekle görevli memur ve müstahdemlerden oluşur. (M. 13). 


\section{Zonguldak \\ Maden Teknisyen Mektebi (1940 - 1949) \\ IKTISATT VEKÂLETI \\ (Son onay makami)}

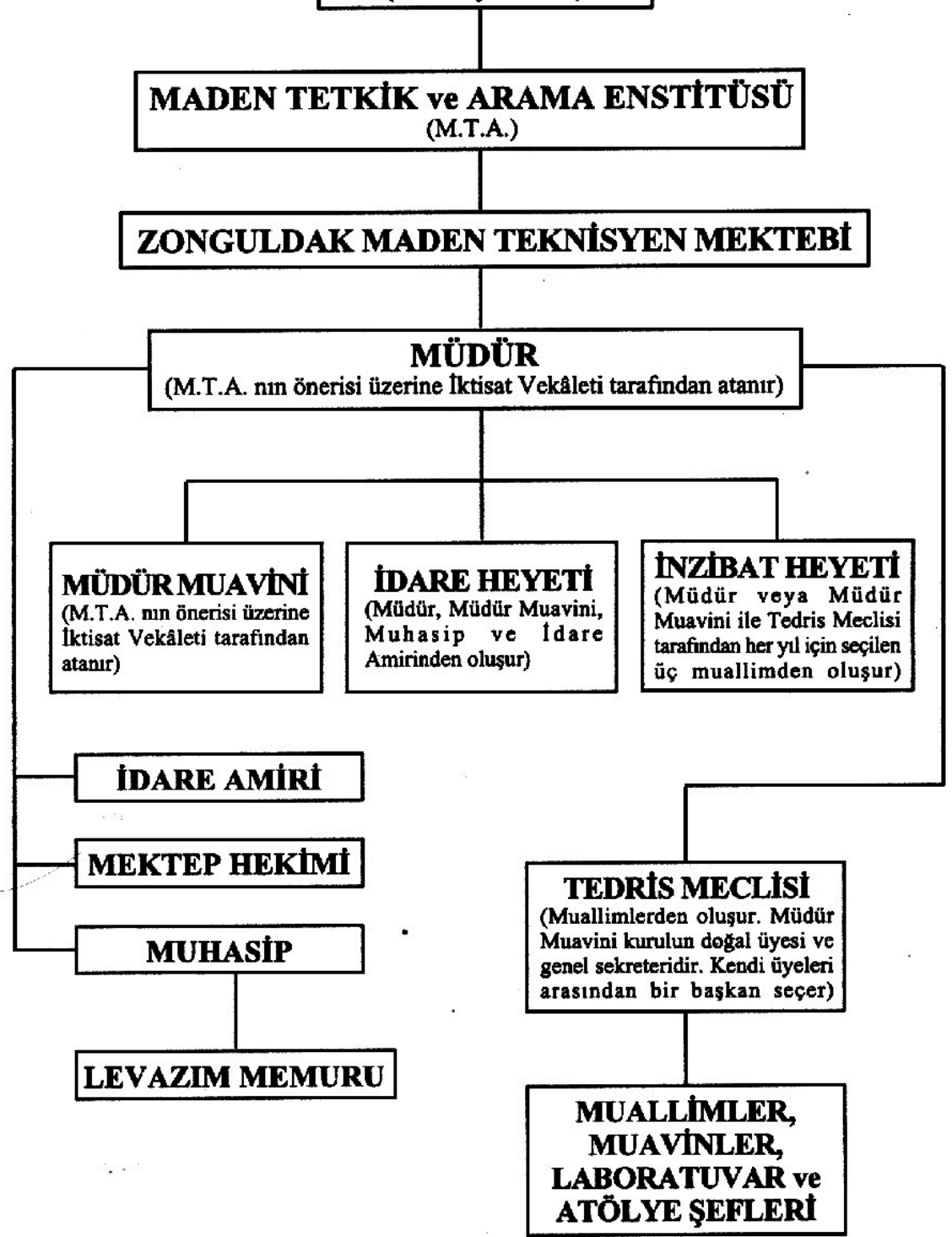

Şekil 7. Zonguldak Maden Teknisyen Mektebi'nin yönetim ve örgütlenme şeması. 


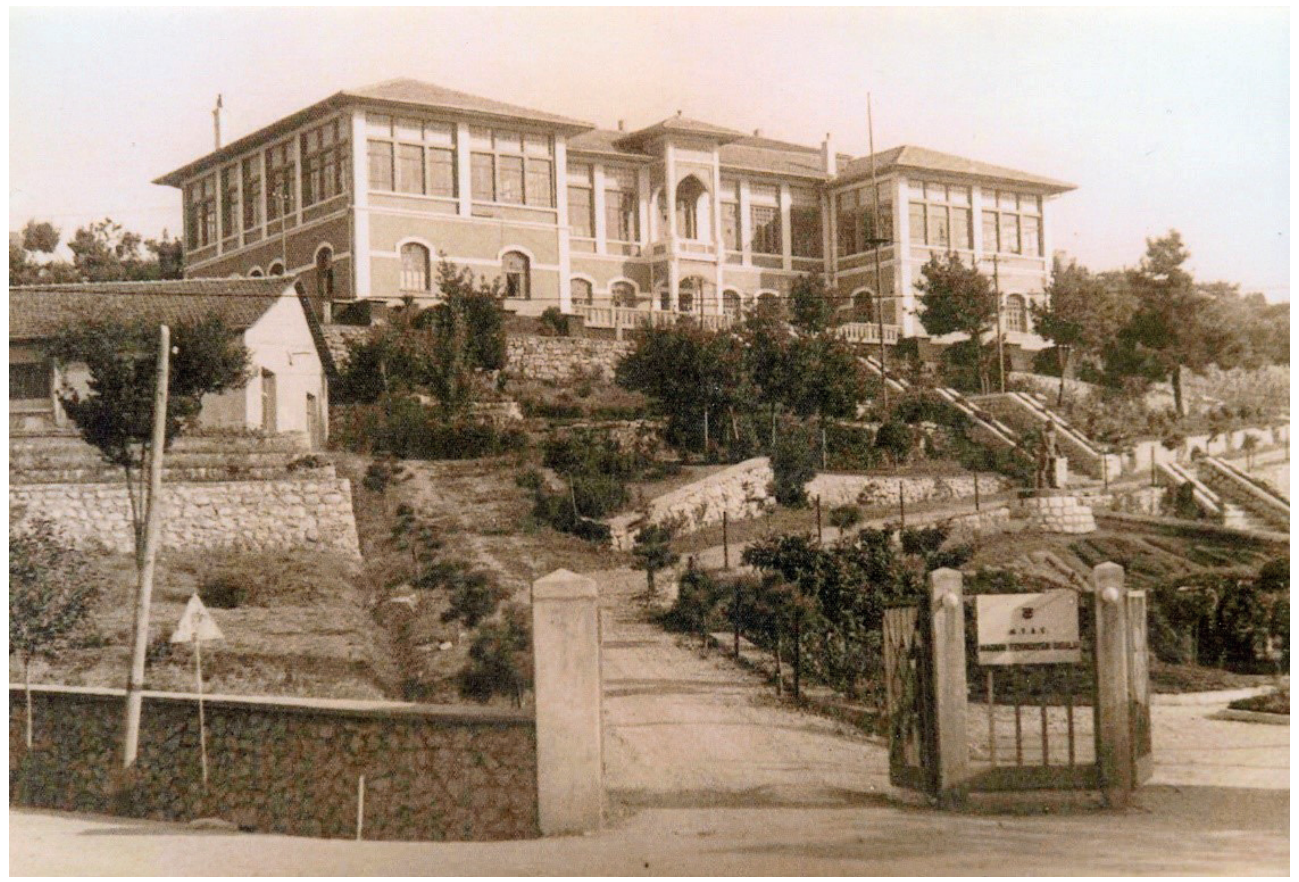

Şekil 8. Eski Maden Mühendis Mektebi binalarına yerleşmiş olan Maden Teknisyen Mektebi'nin giriş kapısı ve kapıdaki tabelası (Yazarın arşivi).

\section{Okulun "İdare Kısmı"}

Müdür: "Mektep, bir mütehassıs müdürün idaresine tevdi” olunmuştur (M. 11). "Müdür, mesleğinde iyi tanınmış yüksek mühendislerden olmak üzere M.T.A. ca inha ve İktisat Vekâletince tayin olunur" (M. 29). "Müdür, mektebin en büyük âmiri olup, umumî idare ile bütün muamelelerin merciidir. Müdür, M.T.A. dan verilen emirlerin ve Tedris Meclisince ittihaz edilen kararların icrasını temin eder" (M. 30).

Müdür muavini: "Müdürün bir muavini vardır" (M. 11). "Müdür muavini de kabil olduğu takdirde yüksek mühendisler arasından intihap ve müdür gibi tayin olunur.” Müdür Muavini, Müdürün emri altında iş görür ve ona yardımcı olur. Müdürün bulunmadığı zamanlarda ona vekâlet eder. "Müdür ve muavini hariçte iş alamaz"lar (M. 31). ${ }^{26}$

26 Okulun açılışından kısa bir süre sonra 14 Mayıs 1941 tarihinde çıkartılan 2/15771 sayılı kararname ile daha yüksek ücret ödenebilmesi için "M.T.A. Enstitüsü teşkilatına dahil Zonguldak Maden teknisyen mektebi Müdür ve Müdür muavinliği vazifelerinin ihtisas mevkii olarak tayinine" karar verilmiştir (BCA, Fon kodu: 30.18.1.2/Yer No: 95.40.6) [EK 7]. 
İdare Heyeti [Yönetim Kurulu]: "İdare Heyeti müdür ve muavini ile muhasip ve idare âmirinden terekküp eder [oluşur]. İdare Heyeti, müdürün daveti üzerine içtima eder [toplanır], mukarrerat [kararlar] ekseriyetle ittihaz olunur [çoğunlukla alınır], mukarrerat defterine kayıt ve imza edilir" (M. 33).

İdare Heyeti'nin görevleri a) okulun her türlü ihtiyacını belirlemek, b) satın alınacak eşyanın örneklerini belirleyerek saklamak, c) satın alınan eşyayı örneği ile karşılaştırarak muayene etmek ve teslim almak, d) levazım memuru tarafından alınan eşyaları denetlemek ve muayene etmek, e) okulun demirbaş eşya ve malzemelerinden hasara uğrayanları veya kullanılamaz duruma gelenleri belirleyerek demirbaş listesinden çıkartmak, f) her ay sonunda veya gerek gördükçe eşya ve erzak ambarlarını denetlemek, ambar mevcudunu saymak ve tartmak ve g) okula ilişkin her türlü harcamanın senet ve bordrolarını onaylamaktır. Adı "İdare Heyeti” olmakla birlikte bu kurulun görevinin bütünüyle mali konular ve satın alma işleriyle sınırlı olduğu görülmektedir.

Inzibat Heyeti [Disiplin Kurulu]: İnzibat Heyeti müdür veya müdür muavini ile Tedris Meclisi tarafından her yılın başında seçilen üç muallimden oluşur. İnzibat Heyeti müdürün çağrısı üzerine toplanır (M. 35). Okulun disiplin işlerine ilişkin olan ve müdür tarafından havale edilen her türlü evrakı inceleyerek karar verir. Kesin çıkarma cezaları M.T.A. nın onaylaması ile yürürlüğe girer (M. 36).

Okul hekimi: "Mektebin hekimi talebenin sağlık sicillerini tutar. Talebe, memur ve müstahdemleri tedavi ve mektep revirini idare eder. Hekim mektebin sağlık şartlarına bakmağa mecburdur” (M. 32).

\section{Okulun "Tedrisat Kısmı"}

Tedris Meclisi: “Tedris Meclisi muallimlerden teşekkül eder" (M. 21). "Meclise muallimler arasından intihap edilen zat reislik eder ve müdür muavini Tedris Meclisi'nin tabiî âzası ve umumî kâtibidir" (M. 22). "Tedris Meclisi tatil devresi müstesna olmak üzere en az ayda bir defa toplanır.” Öğretim yılının ilk ayındaki toplantı müdürün daveti üzerine yapılır. Meclis bu toplantıda belirleyeceği aylık toplantı günlerinde kendiliğinden toplanır. Bu olağan toplantıların dışında kendisinin vereceği karar, Reis'in çağrısı veya üyelerin dörtte birinin yazılı talebi üzerine olağanüstü olarak toplanabilir (M. 23). Toplantılar mektepte yapılır. Toplantının geçerli olması için üyelerin yarıdan bir fazlasının katılımı gereklidir (M. 24). Kararlar hazır bulunan üyelerin çoğunluğu ile alınır (M. 25). Toplantı tutanak ve kararlarının birer örneği her ay sonunda M.T.A. ya gönderilir (M. 26). 


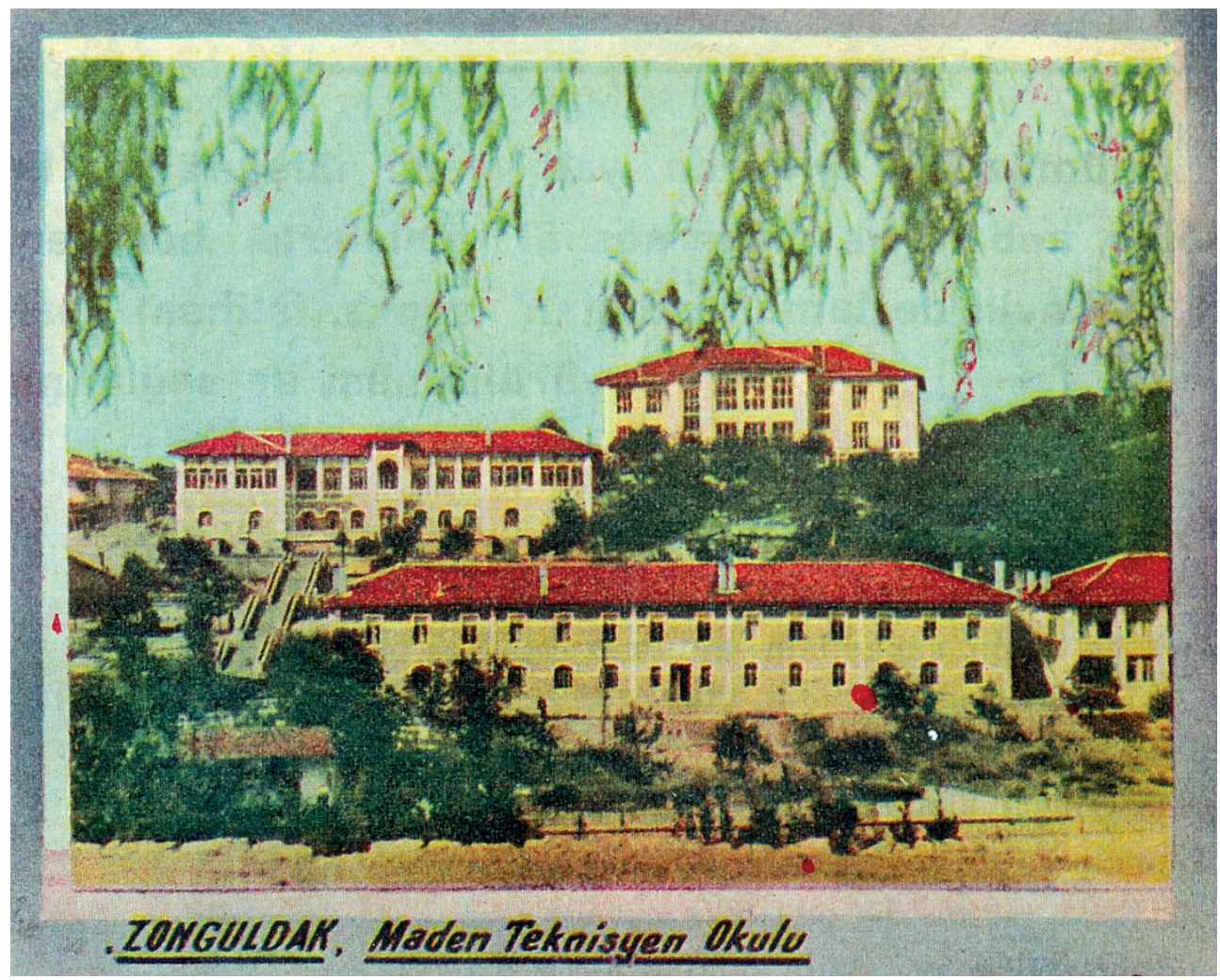

Şekil 9. Zonguldak Maden Teknisyen Okulu'nun genel görünümü (Etibank: 1935 - 1945. Ankara: 1945, 33).

Tedris Meclisi'nin görevleri a) öğretime ilişkin yönetmeliklerin yapılması ve değiştirilmesi, b) derslerin sınıflara dağıtılması ve "lüzum görüldükçe ders konması ve kaldırılması", c) "muallimler ve muavinler kadrosunun tanzimi”, d) "lâboratuvar ve atölye şeflerile muallim ve muavinlerin seçilmesi”, e) öğrenimini bitiren öğrencilere diploma verilmesi ve f) öğretime ilişkin olmak üzere gerekli görülecek diğer konuların konuşulmasıdır. "Bunlardan a, b, c, d, e fikralarındaki hususlar M.T.A. nın tasdikile tamam olur" (M. 28).

Görüldüğü gibi, Tedris Meclisi okulun en üst ve en yetkili organıdır. Müdür bu kurulun üyesi olmadığı gibi “Tedris Meclisi kararlarını tatbika ve M.T.A. Genel Direktörlüğüne bildirilmesi icap edenleri bildirmeğe mecburdur” (M. 27). Tedris Meclisi ile müdüriyet arasındaki ilişki ve iletişim meclisin doğal üyesi ve genel sekreteri olan müdür muavini yoluyla sağlanmaktadır. Meclis başkanını kendisi seçmektedir. 
Muallim ve muavinler: Muallim olabilmek için “en az Yüksek Mühendis Mektebi veya bu derecede bir meslek mektebinden mezun olmuş" veya okutacağı dersin gerektirdiği yüksek öğrenimi görmüş olmak, Maarif Vekâleti'nin öğretmenlerde aradığg niteliklere sahip bulunmak ve en az bir yabancı dili bilmek şarttır. Meslekî olmayan genel derslerin muallim ve muavinlerinden M.T.A. ca bu koşullar aranmayabilir. "Türk muallim bulunmayan ihtisas derslerine mukavale ile yabancı muallim alını"” (M. 18).

"Muallim ve muavinlerle Lâboratuvar ve Atölye Şefleri Tedris Meclisi tarafından seçilirler ve M.T.A. Genel Direktörlüğünce tayin olunurlar.” Bu tayinler İktisat Vekâleti’nin onayı ile kesinleşir (M. 19). "Müsavi şartlar altında muallimliğe tercihan muavinler seçilir" (M. 18). “İlk tedris heyeti M.T.A. ca intihap ve Vekâletçe tayin olunur” (M. 51).

"Muallimler kendi derslerine ait lâboratuvar, atölye ve müzenin âmirleridirler. Muavinlerle diğer teknik memurlar talimatnamelerine tevfikan tedrisatın icra ve idaresinde muallime yardımla mükelleftirler” (M. 17).

"Muallimlervemuavinler arasında her hangi birinin vazifesinde müsamahası, muvaffakiyetsizliği veya hâl ve hareketinde mektebin ve mesleğin şeref ve haysiyetini muhil [ihlâl eden] bir hali görülürse" müdürün teklifi üzerine Tedris Meclisi tarafından yazılı veya sözlü savunması alındıktan sonra üye tam sayısının dörtte üç çoğunlukla alacağı karar üzerine "istifaya davet olunur." İlgili istifa etmediği takdirde olay M.T.A. ya bildirilir. Bunun sonucunda M.T.A. Genel Direktörlüğü’nün vereceği ve İktisat Vekâleti'nin onaylayacağı karara göre davranılır (M. 20).

\section{Ĕgitim ve öğretim}

"Mekteb leylî [yatılı] ve meccanî [parasız] olup talebenin maden ocaklarındaki amelî [uygulamalı] çalışma devresile beraber tahsil müddeti dört senedir” (M. 3).

Talimatnamede stajların yapılması ve değerlendirilmesi ile sınavlar çok ayrıntılı bir biçimde düzenlenmiş olmakla birlikte okutulacak dersler konusunda mektepte genel olarak "riyaziye [matematik], mihanik [mekanik], fizik, kimya, jeoloji, mineraloji, maden işletmesi, elektromekanik, makine, topografya, tahlisiye ve ilk yardım, yapı işleri, maden ve iş mevzuatı, maden iktisadiyatı, maden sanayii muhasebesi, sağlık bilgisi, lisan gibi dersler gösterilir" denilerek genel bir liste verilmiştir (M. 10). Burada derslerin tamamı belirtilmediği gibi bunların sınıflara dağılımı da verilmemiştir. Çeşitli kaynaklarda da birbirinin tekrarı niteliğinde kısa ders listeleri verilmektedir. ${ }^{27}$ Okulun evrakı arasında bulunan elyazısı bir notta ilk üç sınıfın dersleri ayrı ayrı belirtilmiştir [EK 8]. Bu not esas alınarak düzenlenmiş

27 Bu kaynaklarda da dersler sınıf ayrımı yapılmaksızın Türkçe, Tarih, Coğrafya, Matematik, Fizik, Kimya, Beden Terbiyesi, Askerlik, Sağlık Bilgisi, Jeoloji, Mineraloji, Teknik Resim, Elektroteknik, Makine, Atölye, Topografya ve Tatbikatı, Maden İşletmesi ve Tatbikatı, Maden Temizleme ve Kıymetlendirilmesi olarak sıralanmaktadır. ["Maden Teknisyen", 312; Ö. Hasan, "Zonguldak Maden Teknik Arama Mektebinin Bugünkü Durumu," iş 14, 77 (1948): 13. 
olan ders çizelgesi Çizelge 4'de verilmiştir.

"Tedrisat, müdürün idare ve bakımı altında olmak üzere muallim ve muavinler tarafından" (M.15) ve "Tedris meclisince tanzim ve M.T.A. ca tasdik edilecek müfredat ders programlarına göre icra edilir" (M. 14).

\section{Çizelge 4}

Maden Teknisyen Mektebi’nde Okutulan Derslerin Sınıflara Göre Dağılımı

\begin{tabular}{|c|c|c|}
\hline I. Sinif & II. Smif & III. Smuf \\
\hline Türkçe & Türkçe & Türkçe \\
\hline Matematik & Matematik & Matematik \\
\hline Fizik & Fizik & Fizik \\
\hline Kimya & Kimya & Kimya \\
\hline Yabancı Dil & Yabancı Dil & Yabancı Dil \\
\hline Beden Eğitimi & Beden Eğitimi & Beden Eğitimi \\
\hline Askerlik & Askerlik & Askerlik \\
\hline Sağlık & Sağlık & - \\
\hline- & - & Tarih \\
\hline- & - & Coğrrafya \\
\hline Jeoloji & Jeoloji & Jeoloji \\
\hline Teknik Resim & Teknik Resim & Teknik Resim \\
\hline Topografya ve Tatbikatı & Topografya ve Tatbikatı & Topografya ve Tatbikatı \\
\hline Makine & Makine & Makine \\
\hline Maden İşletmesi & Maden İşletmesi & Maden İşletmesi \\
\hline Emniyet & Emniyet & - \\
\hline- & Mekanik & Mukavemet \\
\hline- & Mineraloji & Petrografi \\
\hline- & - & Elektroteknik \\
\hline- & - & Tahlisiye \\
\hline- & - & İş Terbiyesi \\
\hline- & - & Yapi İşleri \\
\hline- & - & Maden İktisadiyatı \\
\hline
\end{tabular}

"Tedrisat, ders takriri [anlatımı] ve müzakeresi, tatbikat yaptırılması, resim ve proje tanzimi, lâyiha [bitirme tezi] kaleme alınması, el işçiliği, lâboratuvar ve atölye çalışmaları, zemin üzerinde ameliyat [yer üzerinde uygulama], fabrikalar ve maden sanayii müesseselerinin ziyareti, fennî [bilimsel] seyahatlar yapılması suretile ifa olunur. Muayyen kitabı olmayan derslerin muallimleri okuttukları dersi makine ile mumlu kâğıt üzerine basılmış ve teksir 
edilmiş olarak talebeye dağıtırlar" (M. 16).

Savaş döneminin sıkıntılı koşullarına rağmen eğitim ve öretim için gerekli altyapı eski birikimin üzerine yapılan katkılarla iyi bir biçimde sağlanmıştır. ${ }^{28}$

"Maden Teknisyen Okulu, mülga Yüksek Maden Mühendis Mektebinde açıldığından evvelce büyük gayretler sarfiyle inşa edilen binalardan, tesisattan, laboratuvarlardan kütüphane ve resimhanelerden öğrenciler bol bol istifade etmektedir. Ahvali hazıranın bütün müsaadesizliği içinde malzeme ve ecza darlığı şiddetle hissedildiği bir zamanda bile azamî gayret ve dikkat sarfiyle kimya ve fizik laboratuvarlarında çeşitli deneyler yapılmakta ve bu deneyleri bizzat öğrencinin de yapabilmesine imkân vermek için gerekli türlü tedbirler alınmış bulunmaktadır. Böylece her iki derste de kuru bir nazariyat yerine daha çok amelî esaslara müstenid bir metod takip edilerek ilerisi için beklenen iyi randımanın alınması sağlanmıştır. Ayni zamanda meslekî iştigal bakımından en çok muhtaç oldukları bilgilerden birisi de muhtelif madenler üzerindeki tetkik ve müşahedelere müstenit meleke ve mümareseden ibaret olacağı gözönüde tutularak bu hususların da gereği gibi temin edilmesi için okulun zengin mineraloji, petrografi, paleontoloji koleksiyonları üzerinde s1k sık tetkikler yapmak firsatı verilerek tabiatın bağrında saklı en kıymetli madenlerin bugün elde mevcut olan örneklerinde uzun ve dikkatli müşahede ve tetkik mümareseleri yaptırılmaktadır. Mektebin bir de atölyesi vardır. Bunun gayesi maden ocaklarında ve maden sanayii işletmelerinde çalışacak olan teknisyen ve başçavuşların çalışma sahalarında her zaman karşılaşacakları alât, malzeme ve makinaları görmek ve bunlar üzerinde burada tatbikat yapmalarını mümkün kılmaktır. Talebenin meslekî bilgileri üzerinde büyük tesiri olacak bu atölye dersinin ehemmiyeti gözönünde tutularak, şimdiki ve yarınki ihtiyaçlara tekabül etmek üzere binanın noksan kısımları 1942 senesinde tamamlanmıştır.!

Her ders yılı "biri nazarî [teorik], diğeri amelî [uygulama] olmak üzere, iki sömestre ayrılmıştır” (M. 3).

Birinci, ikinci ve üçüncü sınıfların nazarî sömestreleri 1 Ekim ve 1 Mart tarihlerinde başlar ve yirmi haftası ders, iki haftası sınavlar olmak üzere 22 hafta sürer. ${ }^{29}$ Dördüncü sınıfın nazarî sömestri dört haftası sınavlara ayrılmış olmak üzere 42 haftadır. Amelî sömestreler "her sene en az dört aydır" (M. 3/A).

Teknisyen Mektebi öğrencilerinin stajlarına büyük öinem verilmekte ve bunlar belirli bir program içinde ilgili maden mühendislerinin sıkı denetimi altında yapılmaktadır. Öğrencilerin amelî sömestrede yapacakları işler okul tarafindan programlanır, adları ve sınıfları her yıl Şubat ve Ağustos aylarında Zonguldak İktisat Müdürlüğü’ne bildirilir. İktisat Müdürlüğü öğrencilerin müesseselere yerleştirilmesini yaparak sonucu Mart ve Eylül ayları sonuna kadar okula bildirilir (M. 3/B).

28 "Maden Teknisyen," $313-314$.

29 Burada açıkça belirtilmemiş olmakla birlikte bir yılda iki tane nazarî sömestre yoktur. Okula yılda iki kez öğrenci alınması nedeniyle bu öğrencilerin nazarî sömestrelerinin başlama tarihleri 1 Ekim ve 1 Mart olmaktadır. Durumun böyle olduğu Talimatnamedeki "Her ders senesi iki devre olup, bu devrelerde mektebe alınacak talebenin adedini İktisat Vekâleti tayin eder” (M. 3) hükmünden anlaşılmaktadır. 


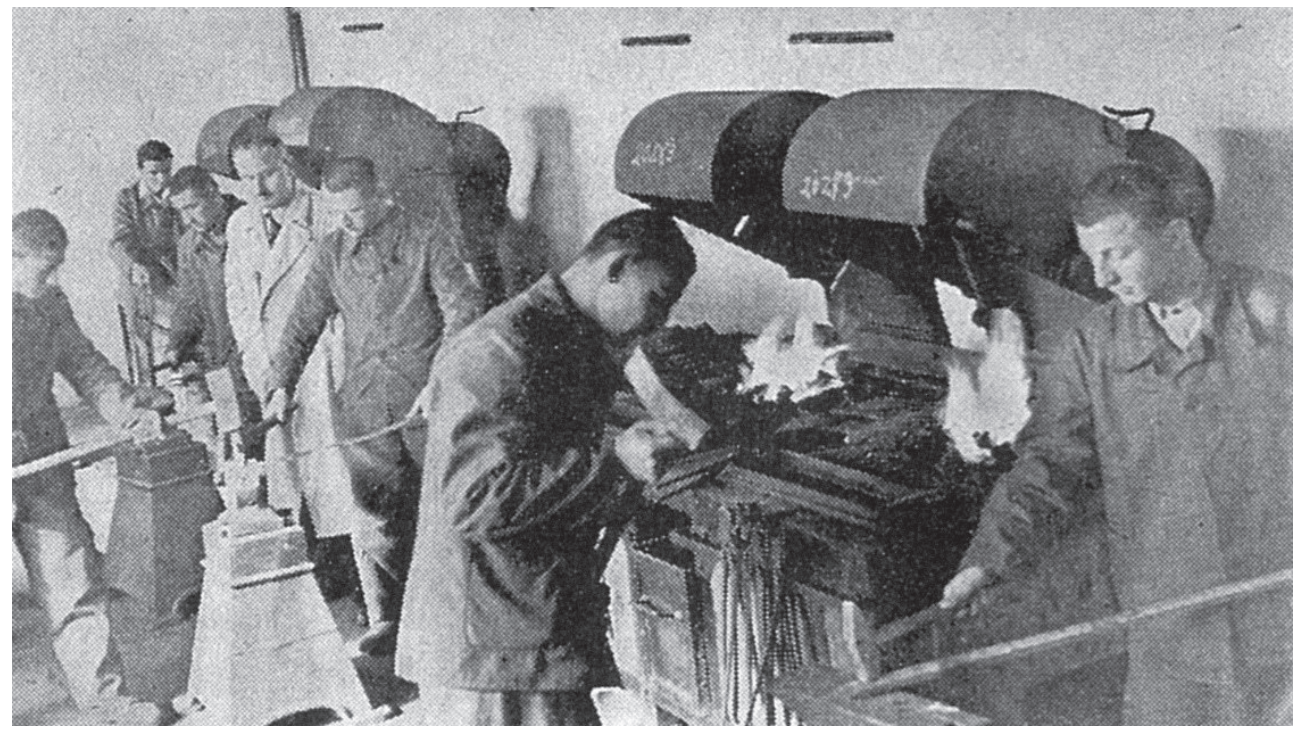

Şekil 10. Maden Teknisyen Okulu öğrencileri demir atölyesinde çalışırlarken (Erkek Teknik Öğretim, Ankara: Millî Eğitim Bakanlığı, 1949, 37).

Müessese yönetimleri her öğrencinin devamını izleyerek bunu özel bir deftere kaydetmeye ve bu kayıtları beş yıl süreyle saklamaya mecburdurlar (M. 3/D). "Her talebe, çalıştığı her günün nasıl geçtiğini, o esnada neler yapıp neler öğrendiğini, aynı akşam kendi jurnal defterine kaydederek ertesi akşam şefine imzalatmaya, her sömestr sonunda mektebine avdet etmeden evvel jurnal defterini müessese müdürlüğüne tasdik ettirmeğe mecburdur. $\mathrm{Bu}$ defterler her sene mektepçe talebe dosyasına konur ve onsuz sınıf geçilmez” (M. 3/E).

Maden Teknisyen Mektebi öğrencilerinin yapacakları stajlara ilişkin esaslar Ereğli Kömürleri İşletmesi tarafından düzenlenerek 29 Temmuz 1944'de 512/158 numaralı servis notu ile Kandilli, Üzülmez, Kozlu, Kilimli ve Gelik bölgeleri başmühendisliklerine gönderilmiştir. Bu yazı ile her işletmede staj yapacak Maden Teknisyen Okulu öğrencilerin adları, staj programları, öğrencilere ödenecek ücretler, staj defterlerinin nasıl tutulacağı, günlük olarak mühendis vekili veya başmadenci, haftalık olarak ocak mühendisi ve aylık olarak da başmühendisler tarafından nasıl denetleneceği ayrıntılı bir biçimde belirtilmiştir. 


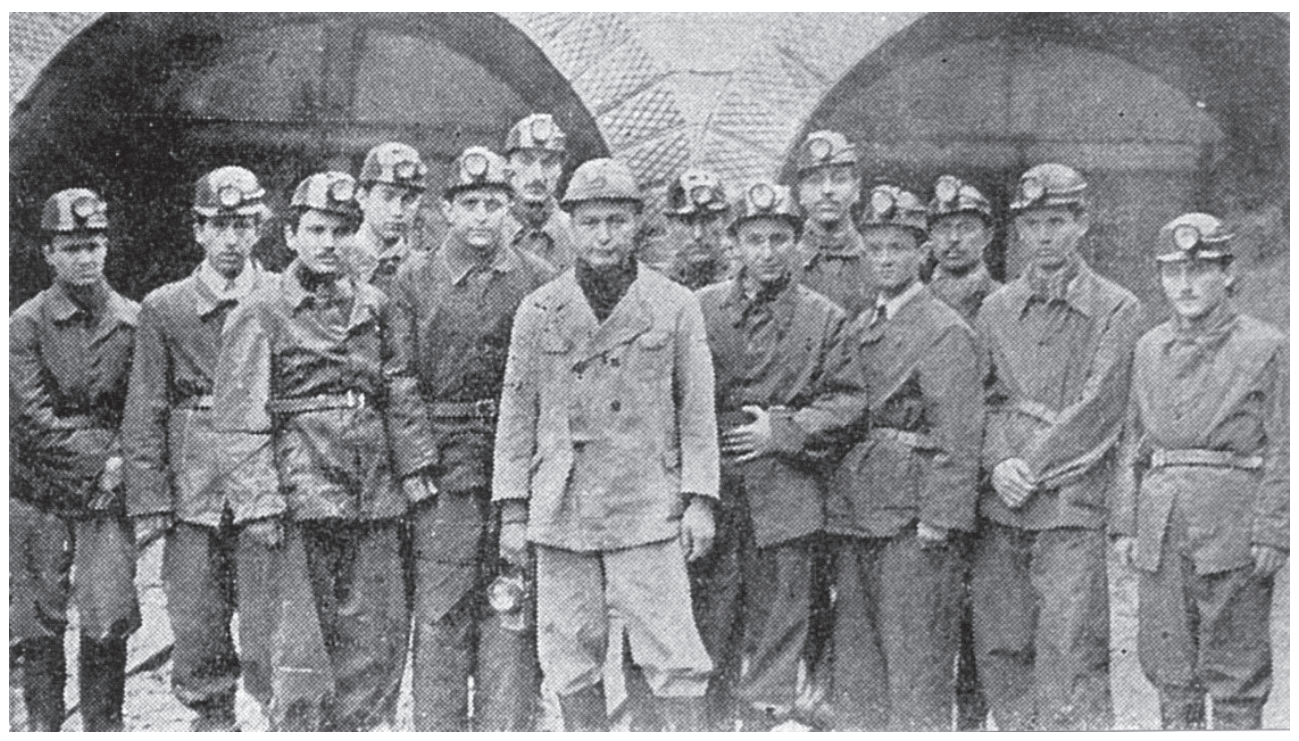

Şekil 11. Maden Teknisyen Okulu öğrencilerinden "ocağa girmeye hazır bir grup öğretmenleriyle birlikte” (Erkek Teknik Öğretim, Ankara: Millî Eğitim Bakanlığı, 1949, 35).

Teknisyen Okulu'nun birinci sınıfını bitirenler dört aylık staj süresince birer ay lağım ve kömür hazırlık işlerinde, kömür üretim işlerinde, çeşitli taşıma, onarım ve işlerinde, ocak içi ve dışında mesaha işlerinde çalıştırılırlar. ${ }^{30}$ İkinci sınıfı bitiren öğrenciler dört aylık staj süresinde birer ay düz, eğik ve dik yolların yapılması ve düzenlenmesi işlerinde (taş, tuğla, beton inşaatı dâhil), ocak içi mekanik tesislerin bakım ve işletilmesiyle havalandırma, ocak gazları ve yangın ile mücadele işlerinde, ocaklarda kronometraj, puantaj, malzeme bakım, dağıtım ve kontrolu ve benzeri teknik ve idari işlerde (Elektroteknik ve benzin lâmbahanelerindeki mesai dâhil), yer altı ve yer üstü ölçüm işlerinde çalıştırılır. Üçüncü sınıfı bitiren öğrenciler altı aylık ehliyet stajlarının Ereğli Kömürleri İşletmesi ocaklarındaki üç aylık döneminde birer ay çeşitli hazırlık ve üretim işleriyle ilgili işletme görevlerinde, ocak içi tesislerin ve mekanik araçların bakım ve işletimi işlerinde, öğrencinin aldığı konu ile ilgisi olan işlerde veya diğer işletme görevlerinde sürveyan (gözetmen) stajyeri olarak çalıştırılır. ${ }^{31}$

30 Stajın zamanında tamamlanamaması konusunda farklı görüşler de ileri sürülmüştür: "Bunlar Temmuzdan itibaren 120 gün ocaklarda staj yaparlar. Bu 120 günü talebe ancak 5 ayda tamamlar, Çünkü talebelerin hastalığı, ocak vaziyetinin müsait olmayışı bu stajı bir ay daha uzatır.” [Ö. Hasan, "Zonguldak Maden", 13].

31 Zaman, Kömürün Çocukları, 157 - 159. 


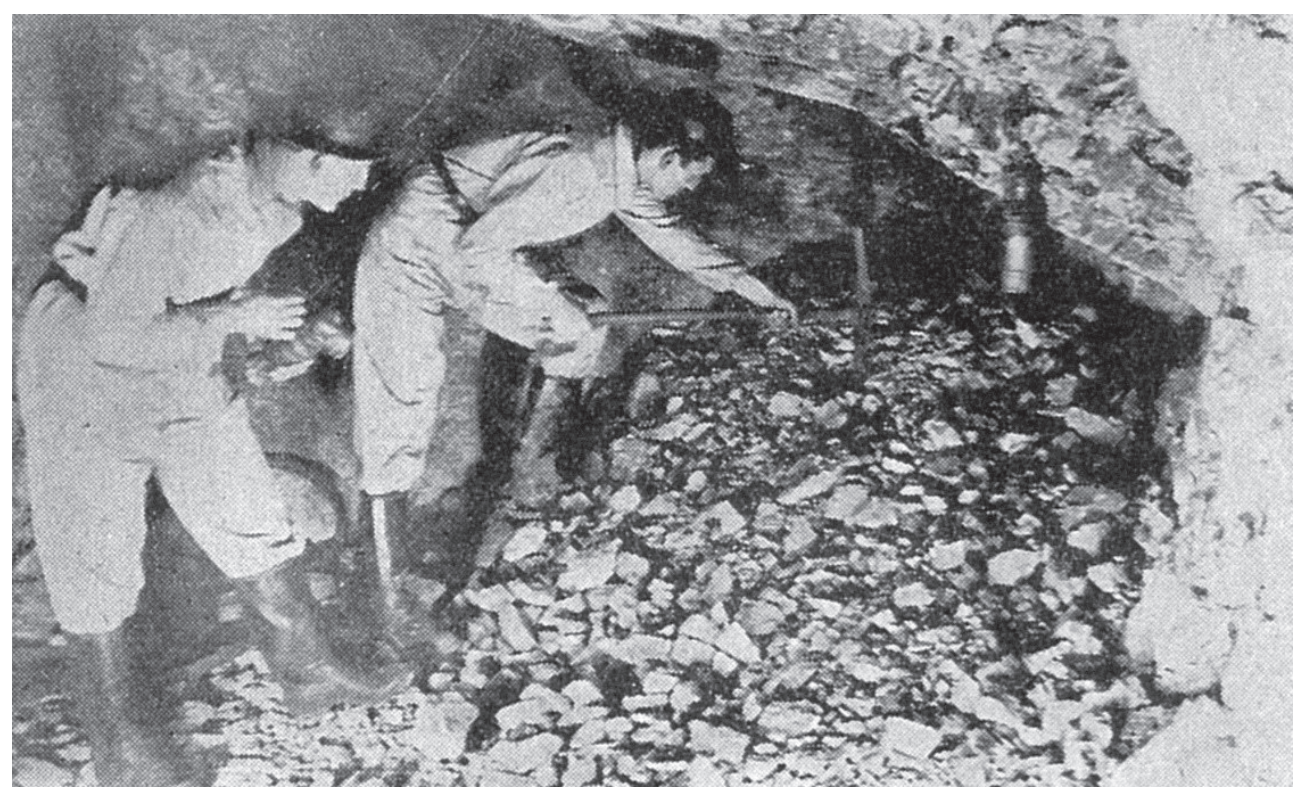

Şekil 12. Maden Teknisyen Okulu öğrencileri ocak içinde çalışırlarken (Erkek Teknik Öğretim, Ankara: Millî Eğitim Bakanlığı, 1949, 37).

Elimizde Maden Teknisyen Mektebi öğrencilerinden 93 numaralı Hasan Mümtaz Gerçek' in 1945 yazında Garp Linyitleri Soma İşletmesi'nde yaptığı staja ilişkin staj defterinin bir örneği bulunmaktadır. Burada öğrencinin hangi çalışmaları yaptığı, yapılan çalışmaların gündelik olarak deftere nasıl işlenip onaylatıldığı, stajın hafta tatili olmaksızın sürdüğü ve öğrencinin işletmeye ilişkin olarak çıkardığı harita, kroki ve çizimler görülmektedir. (Şekil 13 ve 14$)$. 

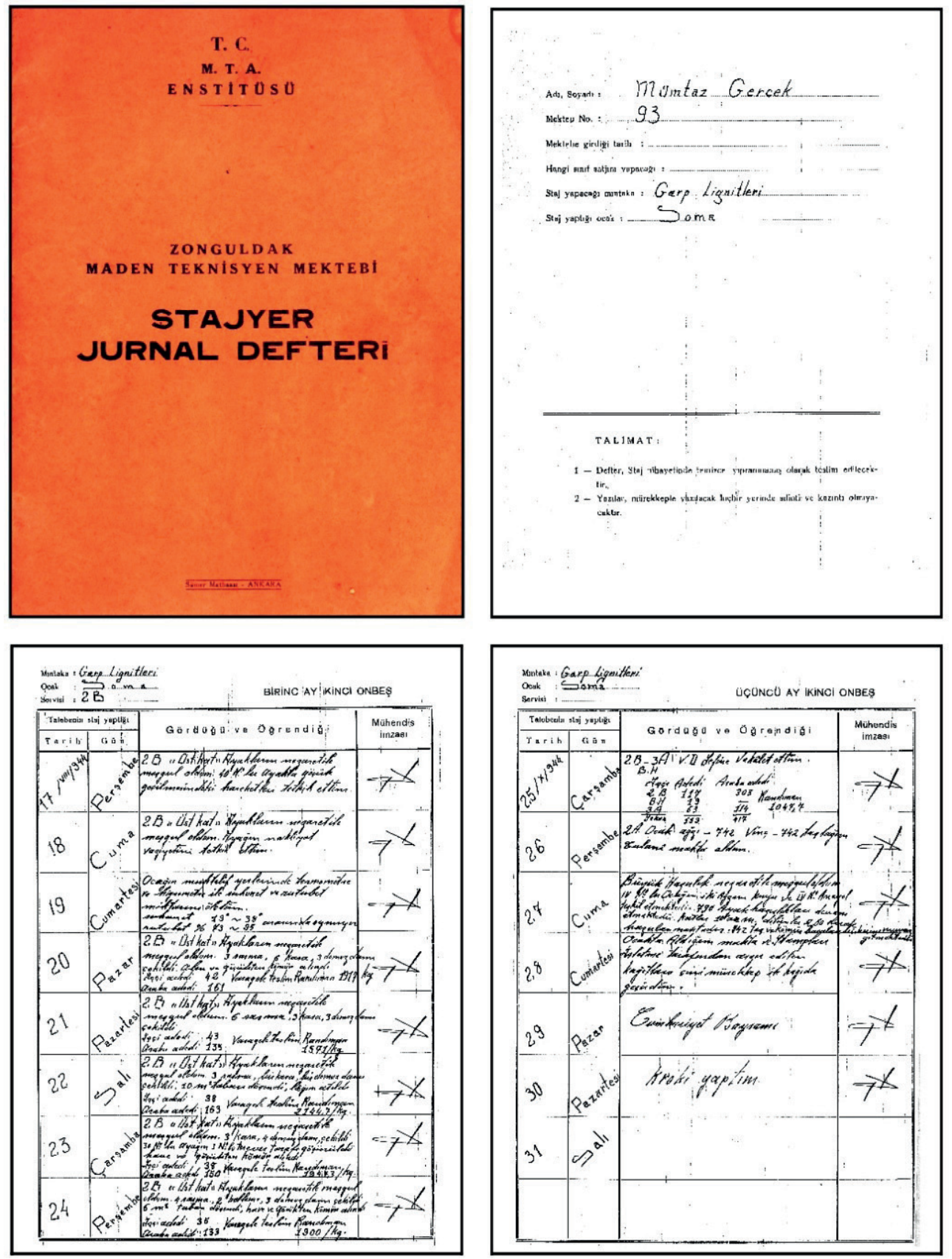

Şekil 13. 1945 yazında Garp Linyitleri Soma İşletmesi'nde staj yapan 93 numaralı Hasan Mümtaz Gerçek'in staj defterinin kapağı, başlangıç sayfası ve sorumlu mühendis tarafından paraflı günlük çalışmalar (Mümtaz Gerçek'in oğlu tarafından yazara verilen fotokopiden, yazarın arşivi). 

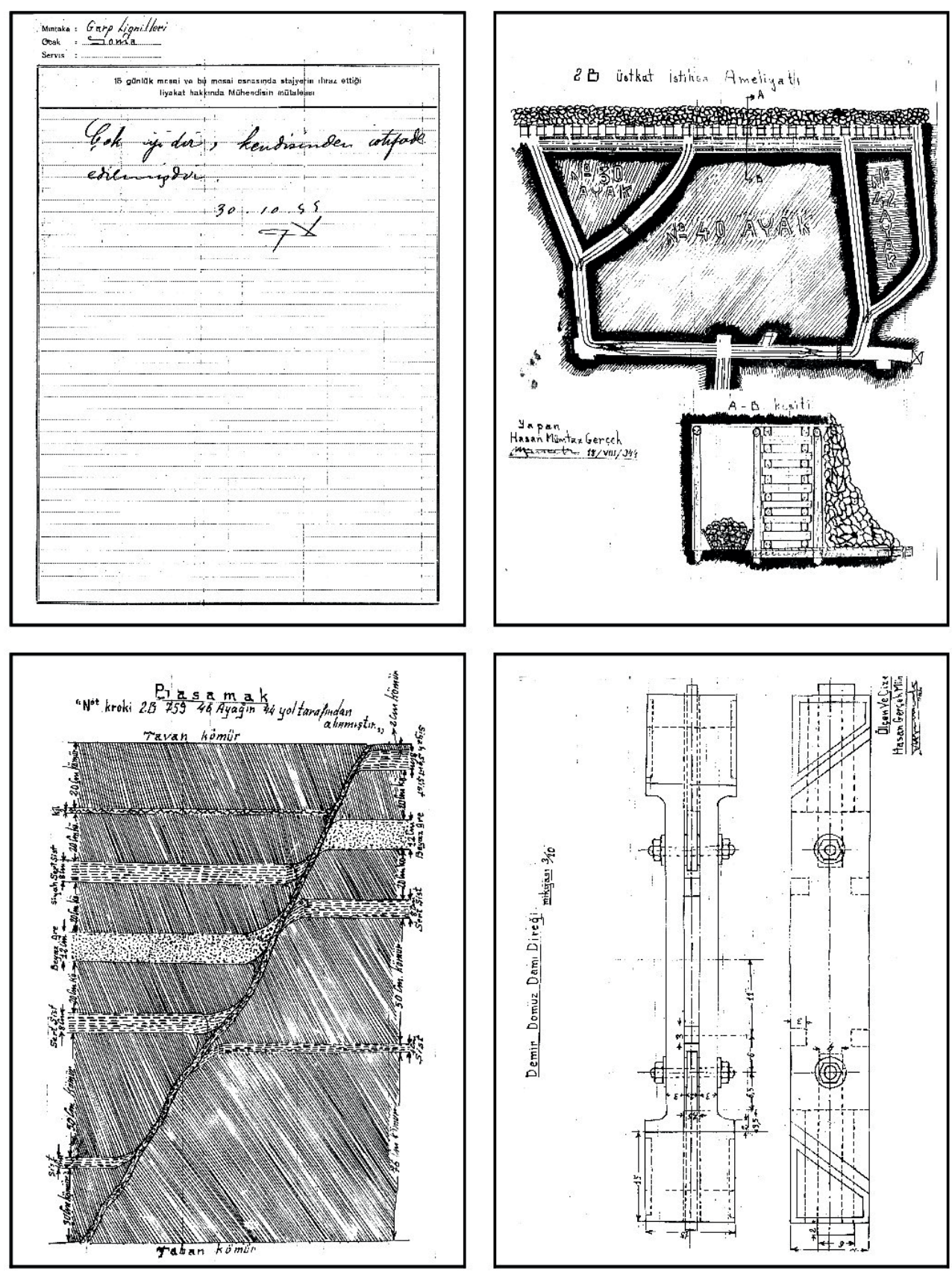

Şekil 14. 1945 yazında Garp Linyitleri Soma İşletmesi'nde staj yapan 93 numaralı Hasan Mümtaz Gerçek'in staj defterinin son sayfası ve yaptığı çizimlerden örnekler (Mümtaz Gerçek'in oğlu tarafından yazara verilen fotokopiden, yazarın arşivi). 


\section{Sınavlar ve sınıf geçme}

Öğrenciler her ay sonunda bütün derslerden yazılı yoklamaya tabi tutulurlar. Sorular yalnız o ay anlatılanlara ait olmayıp daha önce okutulan konuları da kapsayabilir. Yoklama sınavlarında her dersten alınan notların ortalaması ile aynı derslerden genel sınavda alınan notun iki katının toplanıp üçe bölünmesi ile elde edilen not o dersin nazarî sömestrenin başarı notunu oluş̧urur (M. 4).

Notlar 10 üzerinden verilir ve geçer not 6'dır. Not ortalaması 6 tutanlar 4 ve altındaki not aldıkları derslerden ikmale kalıllar. Not ortalaması 6 nın altında kalanlar sınıf geçemezler. Birinci, ikinci ve üçüncü sınıflarda toplam olarak iki kez sınıfta kalanlar (M. 6) ile son sinıfta ikinci kez başarısız olanlar (M. 8) okuldan çıkartılır.

Öğrencilerin sınıf geçmesi her iki sömestredeki çalışmasının sonucuna göre belirlenir. Amelî sömestrede başarılı olamayan veya süresini dolduramayan öğrenciler nazarî sömestrede başarılı olsalar da sınıf geçemezler (M. 3/F).

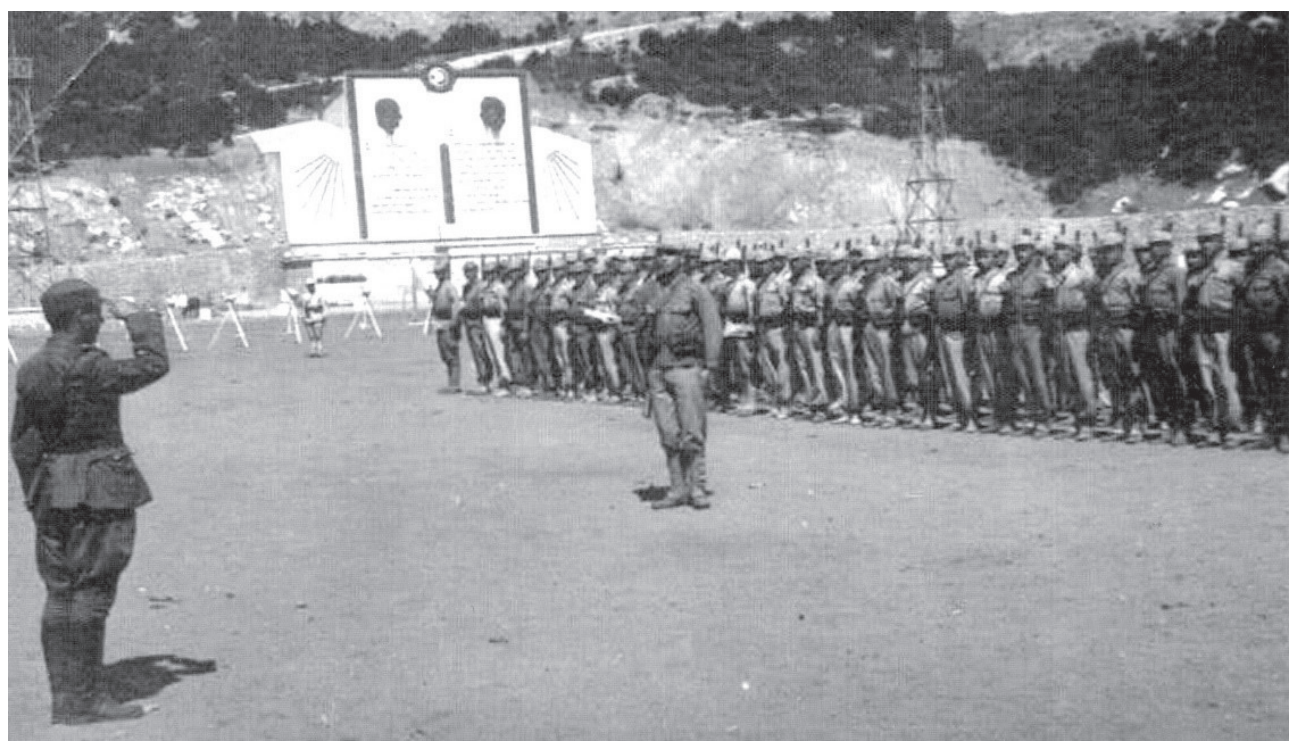

Şekil 15. 1930'lu yıllar ile 1940’lı yılların ilk yarısında orta ve yüksek öğrenim öğrencileri yaz tatillerinde askeri eğitim kampına alınırlar ve daha sonra askere gittiklerinde bu süreler eğitim sürelerinden düşülürdü. Burada Maden Teknisyen Mektebi öğrencilerinin askeri eğitimleri sırasında ouşturdukları birlik görülmektedir (Yazarın arşivi). 
Bitirme sınavı "her dersin muallimi ve İktisat Vekâleti tarafından seçilecek iki mümeyyiz huzurunda" yapılır. Mezun olabilmek için her dersten sözlü ve yazılı olarak yapılan bu sınavlarda başarılı olmak şarttır. Geçer not 6 dır. Genel ortalaması 6 veya daha yüksek olanlar 6 dan düşük not aldıkları derslerden ikmal sınavına girerler (M. 8). Okulu başarı ile bitirenlere "Maden Teknisyeni”" unvanı verilir (M. 9).

Esas Talimatname'de mezuniyet bu biçimde kurala bağlanmış olmakla birlikte uygulamada farklılık vardır. Buna göre, bitirme sınavlarında başarılı olanlar "teknisyen namzedi” adı altında ocaklarda staj yapıp “evvelce her öğrenciye seçilerek verilen mevzulara ait etüt raporlarını öğretim heyetine kabul ettirdikten sonra okul idaresince tespit edilen günde Ekonomi Bakanlığınca seçilen iki üyenin bulunduğu bir kurul huzurunda sözlü bir imtihana tabi tutulurlar. Bu imtihanda muvaffak olanlara (Maden Teknisyeni) diploması verilir", ${ }^{32}$

Öğrenciliğe giriş: Okula öğrenci olabilmek için Türk vatandaşı olmak, iyi hal ve ahlâk sahibi olmak, tam sağlıklı ve "bünyesi tahsile ve madenciliğe elverişli bulunmak", en az ortaokul veya bir sanat okulu mezunu, 18 yaşını bitirmiş ve 25 yaşını geçmemiş olmak ve giriş sınavlarında başarı kazanmak gereklidir (M. 40). (Şekil 16 ve 17).

Devam ve disiplin: "Nazarî her sömestr zarfında devam nisbeti $2 / 3$ tür. Hastalık dahi olsa, bundan az devam eden talebe imtihana giremez ve sınıf geçemez" (M. 7). "Tedrisatın başladığı tarihten itibaren makul mazereti olmaksızın bir ay müddetle mektebe devam etmiyenlerin kayıtları silinir” (M. 41). Öğrenciler okulun düzenine ve yönetmeliklerine uymak, yöneticilere ve öğretmenlerine saygılı davranmak ve itaat etmek, derslerine düzenli olarak devam etmek ve çalışmak, arkadaşlarına karşı terbiye ve nezaketle davranmak, "velhasıl her hususta salim ve dürüst bir hattı hareket takip eylemek vazifesi ile mükelleftir" (M. 38). Öğrenciler her yerde öğrencilik şeref ve haysiyetine uygun davranmak, temiz ve düzgün kıyafette gezmek ve kendilerine verilen yer ve eşyayı iyi korumak zorundadırlar (M. 39).

32 "Maden Teknisyen," 312. Aynı uygulama 1949'da yayınlanmış olan Erkek Teknik Öğretim (Ankara: Millî Eğitim Bakanlığı, 1949) adlı kitapta "IV. Sınıfta bulunan öğrencilerden öğretim yılı sonunda yapılan imtihanlarda başarı gösterenlere tasdikname verilir. Ocaklarda altı ay teknisyen namzedi sıfatiyle başarılı staj gördükten sonra etüt raporunu hazırlayan ve yapılan imtihanlarda muvaffak olanlar (Maden Teknisyeni) diploması alırlar" denilerek konuya açıklık getirilmektedir [Erkek Teknik Öğretim, 35]. 


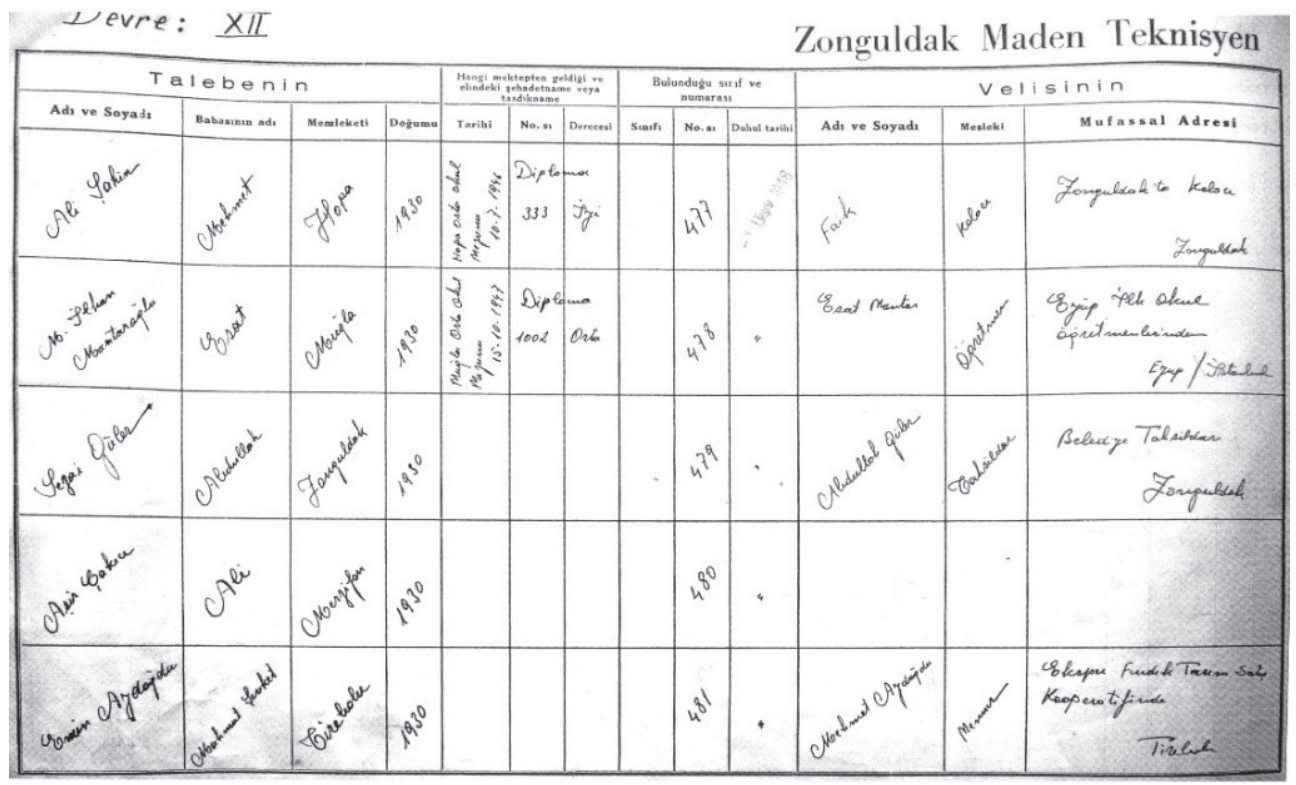

Mektebi Talebe Künye Defteri

\begin{tabular}{|c|c|c|c|c|c|c|c|c|c|c|c|c|}
\hline \multicolumn{3}{|c|}{ Taahhüt senedinin } & \multicolumn{3}{|c|}{ Kefilinin } & \multicolumn{2}{|c|}{$\begin{array}{c}\text { Mokttobl } \\
\text { terkl sebepleri }\end{array}$} & \multicolumn{3}{|c|}{ Mezuniyet Sehadet namesinin } & \multirow{2}{*}{ M ülâh a za t } & \multirow{2}{*}{ Fotograf } \\
\hline Natertisy & Teriat & No.. & Adr ve Soyadt & Mostest & Mufasesal Adroasi & Teriba & Sobbopient & Tantut & No... & Dortonent & & \\
\hline & ! & $\because$ & $a^{x^{*}}{ }^{*}$ & & 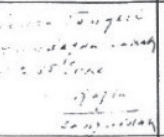 & & & & $1 / 1$ & $y_{y} i$ & 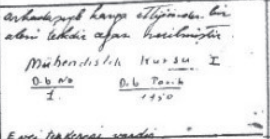 & \\
\hline & & $\hat{n}^{0}$ & & & & & & & $2 / 2$ & ${ }^{7} y^{\prime}$ & 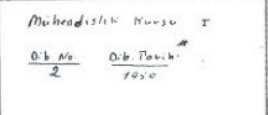 & \\
\hline & 6 & $i$ & & & & & & & $3 / 3$ & byi & 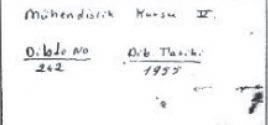 & \\
\hline & $n$ & $\frac{i}{1 / i^{2}}$ & ' & $y^{2}$ & & & 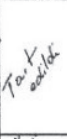 & 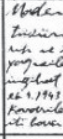 & 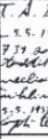 & tim & 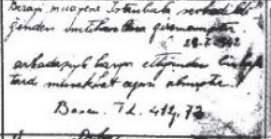 & \\
\hline & 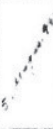 & $1 / 6$ & & & 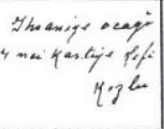 & 6 & 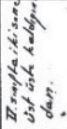 & & & at & 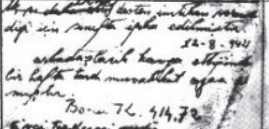 & \\
\hline
\end{tabular}

Şekil 16. Maden Teknisyen Mektebi öğrenci kayıt defterinden bir sayfa (Zonguldak Maden Teknisyen Mektebi arşivi). 

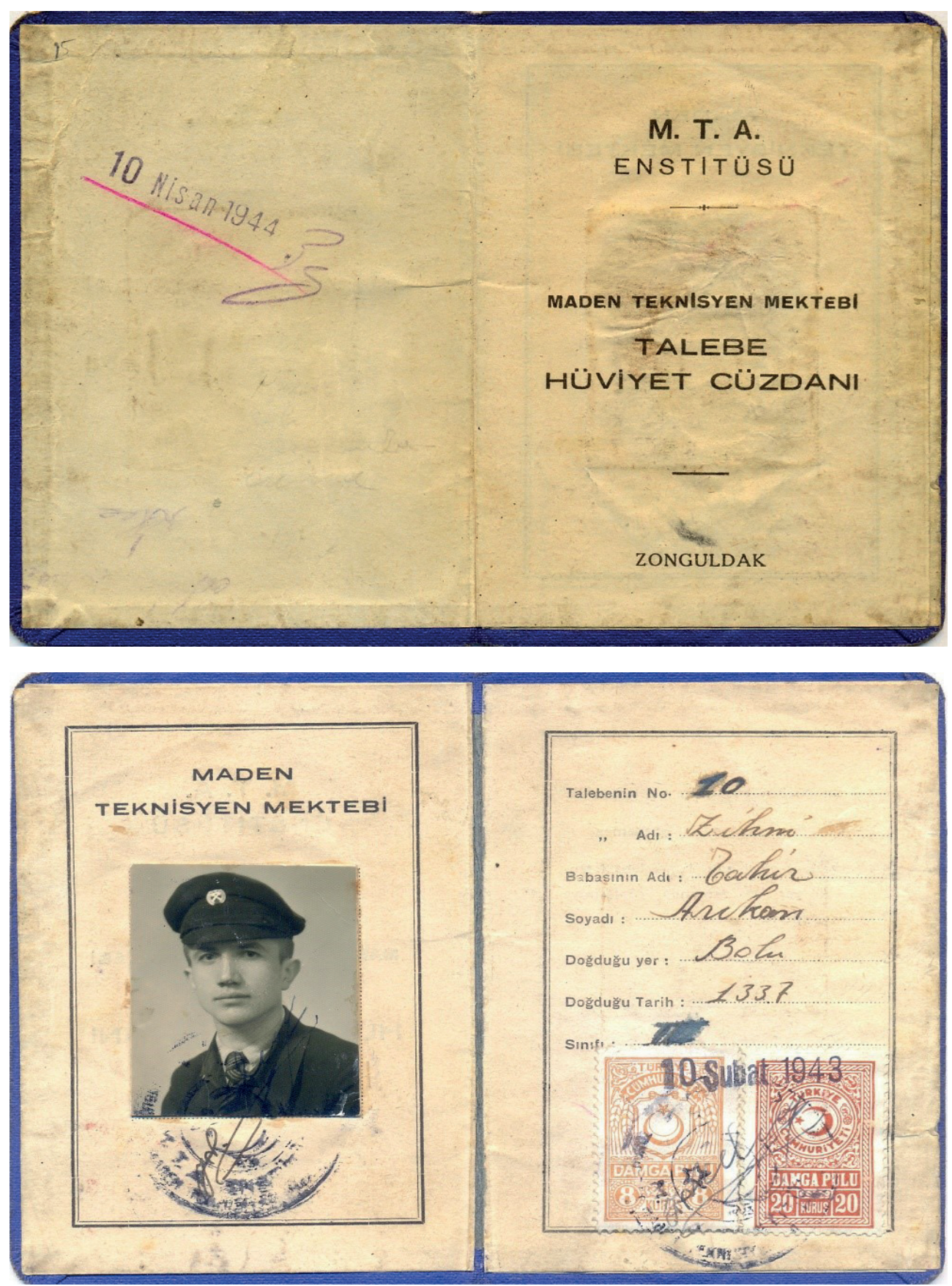

Şekil 17. Maden Teknisyen Mektebi'nin ilk öğrencilerinden olup halen üçüncü sınıfta bulunan 10 numaralı Zihni Arıkan'na 10 Şubat 1943 tarihinde verilmiş olan kimlik (Yazarın arşivi). 
Disiplin kurallarına uymayan öğrencilere disiplin suçunun ağırlığına göre müdür tarafından sözlü olarak "ihtar" veya yazılı olarak "tekdir", İnzibat Heyeti tarafından "muvakkat tard [geçici çıkartma]" ve M.T.A. tarafından "kat'î tard [kesin çıkartma]" disiplin cezaları verilir (M. 47).

Kurallara uymayanların cezalandırılmasına karşılık başarılı olanlar da ödüllendirilir. "Nazarî ve amelî mesaileri esnasında hüsnü hali ve muvaffakiyeti görülen talebeye Tedris Heyeti kararile ocak ve işletmelerde kazandığı ücretin yüzde yirmisine kadar nakdî mukâfat [parasal ödül] verilebilir" (M. 49).

İaşe ve ilbas [Beslenme ve giyim]: Öğrencilere her yıl kasketi ile birlikte bir takım okul üniforması, spor elbisesi, ayakkabı, altı kat çamaşır, altı çift çorap, altı tane mendil, ocakta kullanılmak üzere bir işçi elbisesi ile ayakkabı ve iki yılda bir palto verilir (M. 45/a).

Öğrencilere öğrenim süresince ve yalnız nazarî sömestrelere özgü olmak üzere her ay 6 lira cep harçlığı verilir (M. 3/G). Amelî sömestreler "müddetince talebe madenlerde ve maden sanayii işletmelerindeki kazancı ile geçinir" (M. 3/B). "Amelî sömestreler esnasında müesseseler talebeye liyakatine göre gündelik tahakkuk ettirecekse de asgarî yevmiye 120 kuruş olacaktır" (M. 3/C).

“Öğle ve akşamları ikişer kap yemek verilecek ve haftada ayrıca iki defa tatlı ve bir defa da börek ilâve edilecektir. Kuru ve yaş meyva tatlı yerine verilebilir. Bundan başka sabah kahvaltılarında çayla beraber peynir ve zeytin verildiği gibi, bunlar yerine çorba da verilebilir" (M. 45/b). "Talebe muallimi refakatinde olarak maden ocaklarını ziyarette veya fennî tetkik seyahati yaptıklarında iaşeleri tutarı olan bedel ya kendilerine verilir veyahut bu bedel ile mezkûr mahalde iaşeleri temin olunur" (M. 46).

Sağllk: Öğrencilerin sağlık sicilleri okul hekimi tarafindan tutulur (M. 32). "Talebenin sıhhî durumu her iki ayda bir umumî muayeneye tâbidir ve bu vaziyet talebenin sıhhî durumu hakkında tutulacak defterine her talebe için ayrı ayrı kaydolunur" (M. 43). "Gerek hastalık ve gerek istirahat dolayısile mektepte kalması muvafık görülmiyecek talebeye sıhhî teşkilâtın lüzum gösterdiği müddetçe mezuniyet [izin] verilir” (M. 44). (Şekil 18). 


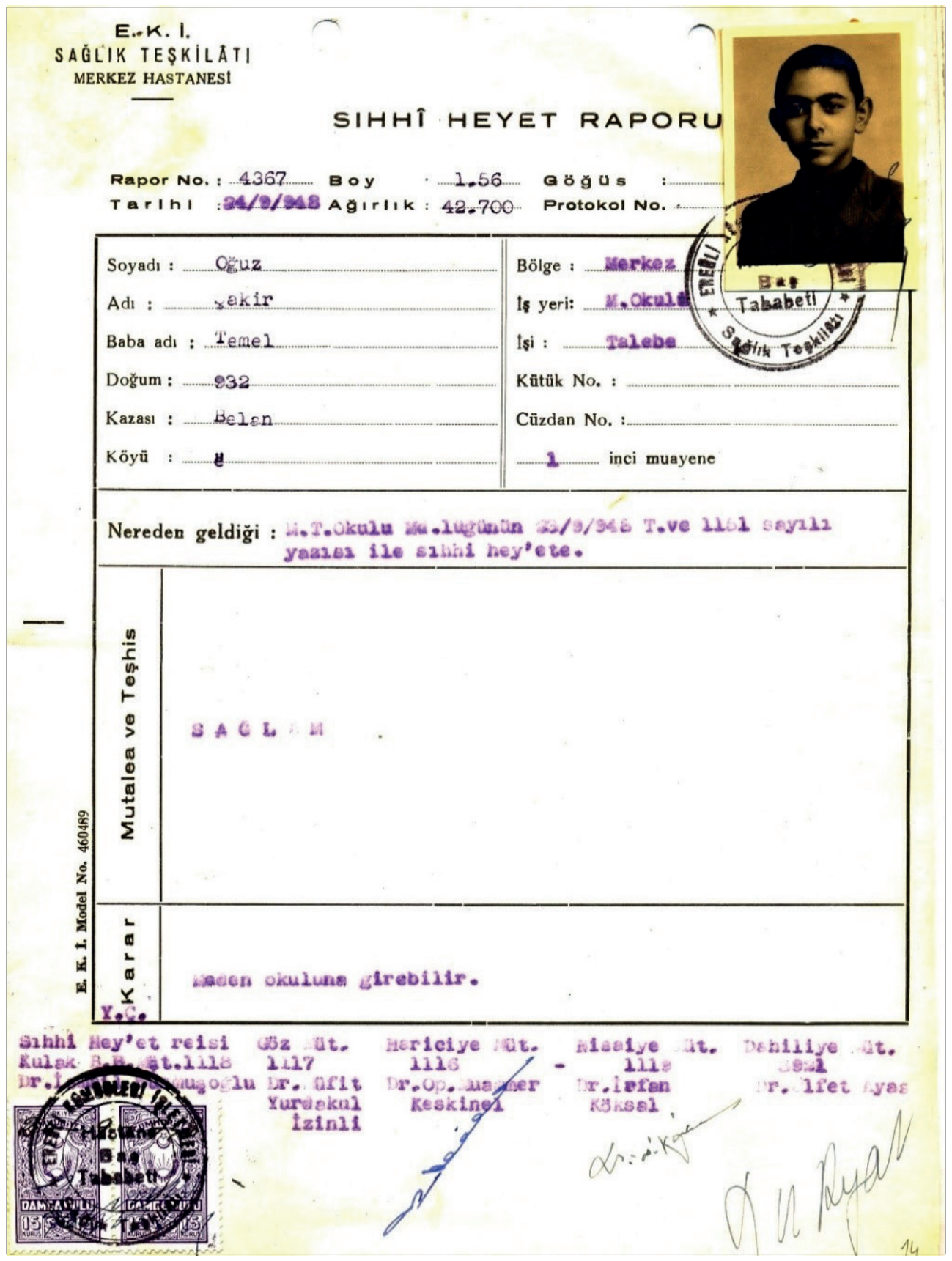

Şekil 18. Maden Teknisyen Mektebi öğrencisi Şakir Oğur'a Ereğli Kömürleri İşletmesi Sağlık Teşkilâtı Merkez Hastanesi tarafından verilmiş olan 23 Eylül 1948 tarihli Sıhhi Heyet Raporu (Yazarın arşivi). 
Mecburî hizmet: "Mektep mezunları, İktisat Vekâletinin göstereceği mahallerde ve maden sanayii işlerinde beş sene müddetle çalışmağa mecburdur” (M. 2). Öğrenciler ancak öğrenimlerini sürdürmelerine engel bir sağlık nedeninin varlığının sağlık kurulu raporu ile belgelenmesi durumunda M.T.A. nın onayı ile okuldan ayrılabilirler. Öğrenciler bundan başka bir nedenle okuldan ayrılamazlar. Okula girişte öğrenciden veya velisinden veyahut vasisinden mecburî hizmetini yapmadığı veya öğrenimini bıraktığı veyahut talimatname uyarınca kaydı silindiği takdirde öğrenim süresince kendisine yapılan masrafi faizi ile birlikte ödeyeceğine dair noterden tasdikli bir taahhütname alınır (M. 37). (Şekil 19 ve 20).

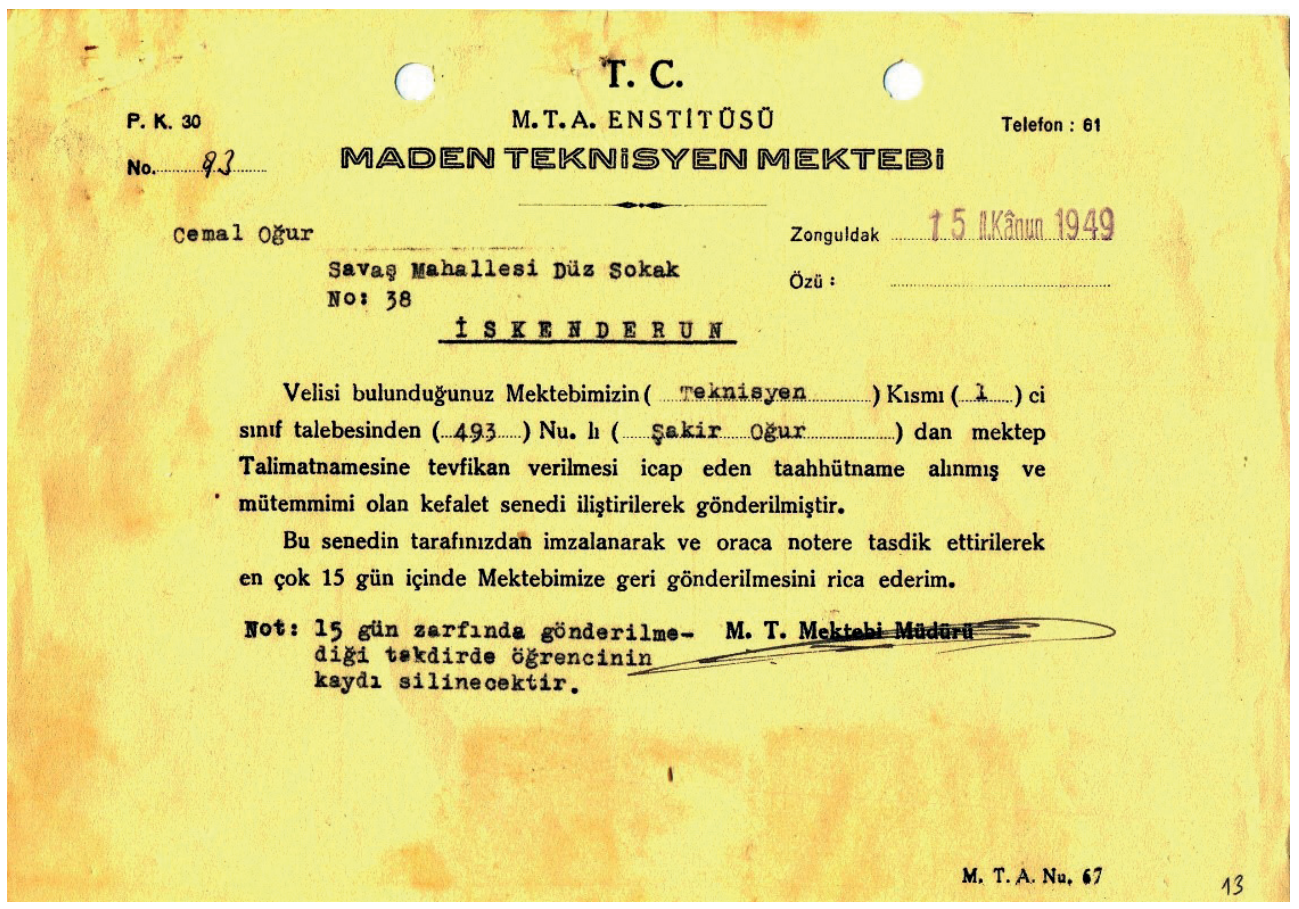

Şekil 19. Maden Teknisyen Mektebi öğrencilerinin okuldan ayrılmaları veya mecburi hizmete gitmemeleri durumunda kendilerine yapılmış olan masrafın geri ödenmesini sağlamak için velilerinden noterden tasdikli kefalet senedi alınmaktadır. Maden Teknisyen Mektebi Müdürlüğü’nün buradaki 15 Aralık 1949 tarihli yazısı ile birinci sınıf öğrencisi 493 numaralı Şakir Oğur'un velisinden kendisine gönderilen kefalet senedini noterden onaylatarak 15 gün içinde geri göndermesi istenilmekedir (Yazarın arşivi). 


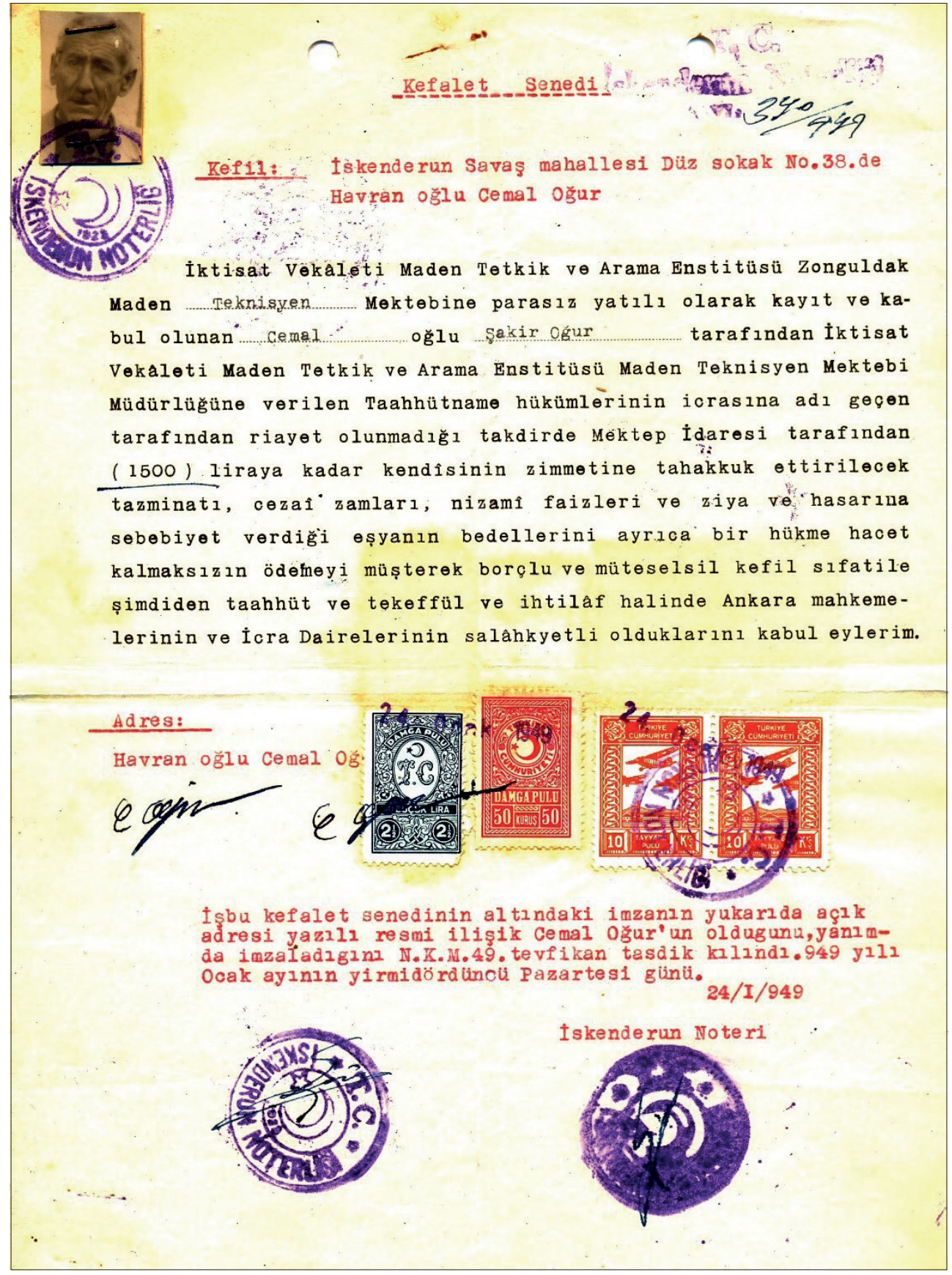

Şekil 20. Maden Teknisyen Mektebi birinci sınıf öğrencisi 493 numaralı Şakir Oğur'un velisinin verdiği noterden onaylı kefalet senedi (Yazarın arşivi). 


\section{Bir gazetecinin okul konusundaki izlenimleri}

Gazeteci Niyazi Acun 1947'de Zonguldak Maden Teknisyen Mektebi'ni ziyaret etmiştir. Yüksek Maadin ve Sanayi Mühendisi Mektebi'nin kapatılmasının yanlışlığı üzerinde uzun uzun durarak okulun yeden açılmasını önermektedir. Bu okulun binalarında faaliyet gösteren Zonguldak Maden Teknisyen Mektebi konusundaki gözlemlerini aşağıdaki şekilde aktarmaktadir: ${ }^{33}$

Okul binasını geziyoruz. Okulun faaliyet sahası çok geniş, büyük iki laboratuvarı var: 1 - Kimya, 2 - Fizik. Okulun bu yeni laboratuvarları havzanın en zengin ve en hassas aletleriyle mücehhez bulunuyor. Bütün bu teçhizat "Yüksek Maden Mühendis Mektebi" açılırken alınmış. Çok iyi muhafaza edilmiş ve ediliyor...

Mineraloji Salonu: Salona girdiğim vakit ortada camlı büyük dört beş sıra dolaplarda büyük bir itina ve ilmî bir tasnifle yerleştirilmiş olan çok zengin koleksiyonlara şöyle bir baktım. Bu koleksiyonlar diyebilirim ki, belki bugün Avrupa kıtasında dahi yoktur. - Harb, darp içinde Avrupa' da akademik ilmî müesseseler harap olmamış ise yoktur diyemeyiz. - Yalnız şurasını memnuniyetle kaydedebilirim ki, Balkanlarda ve Yakın Doğuda bir eşi bulunmıyan taş, mineral ve fosil koleksiyonuna malik oluşu göğsümüzü kabartacak bir varlıktır.

Salon duvarlarını aynı zamanda süsliyen dört zamanı gösteren tablolar, taş, toprak, nebat, hayvan ve ilk kuş, ilk hayvan nümuneleriyle dolu olan bu salon M.T.A. nın yeniden kuracağ 1 yüksek maden mühendisleri için en modern bir çalışma salonu olacaktır.

Hâkim bir tepe üzerine kurularak Karadeniz' in sularına Türk maden ilminin 1şı̆̆ını aksettiren okul beş binaya sığdırılmıştır. Bunlardan birisi idare ve lojman, ikincisi dershaneler, üçüncüsü yatakhane ve laboratuvarlar, dördüncüsü jimnastikhane ve kapalı spor salonu aynı zamanda karbonifer etütleri yazıhanesi, beşinci bina atelyesidir (Şekil 21).

Yatakhane ve yemekhaneleri bol 1şıklı tertemizdir. Okul talebeleri bugün madenlerde ders görmeğe gittiklerinden okulda tedrisat göremedik. Yalnız kimyahane ve laboratuvarlar çalışmakta idi.

Okulun atelyesinde marangozluk, tesviyecilik ve motörcülük dersleri de gösterilmektedir. Madencilik için lâzım olan bu tedrisatı talebeye esaslı surette göstermek için vinç, dinamolar, yer altında lâzım olan makineler; birçok motörlerin maktaı açılmış.

Okulun her ihtiyacı fazlasiyle temin edilmiştir. Okul kurulurken gençlerin stadyumu da yapılmış....

Mineraloji salonunda çok zengin koleksiyonlar karşısında dünyanın beş zamanının bir sinema şeridi seyreder gibi seyrederek okulun ideolojisini bir kere daha anlamış oldum.

33 Niyazi Acun, Toprakaltı Servetlerimiz - “Maden Tetkik ve Arama Enstitüsü” Çalışmaları (İstanbul: Sinan Basımevi, 1947), $74-76$ ve $86-87$. 
Maden Tetkik ve Arama Enstitüsü’nün büyük ihtimam ve gayretleriyle yüzümüzü güldüren ve madenciliğimize renk ve kuvvet veren bu müessesenin istikbali madenlerimiz kadar parlak ve ebedidir.

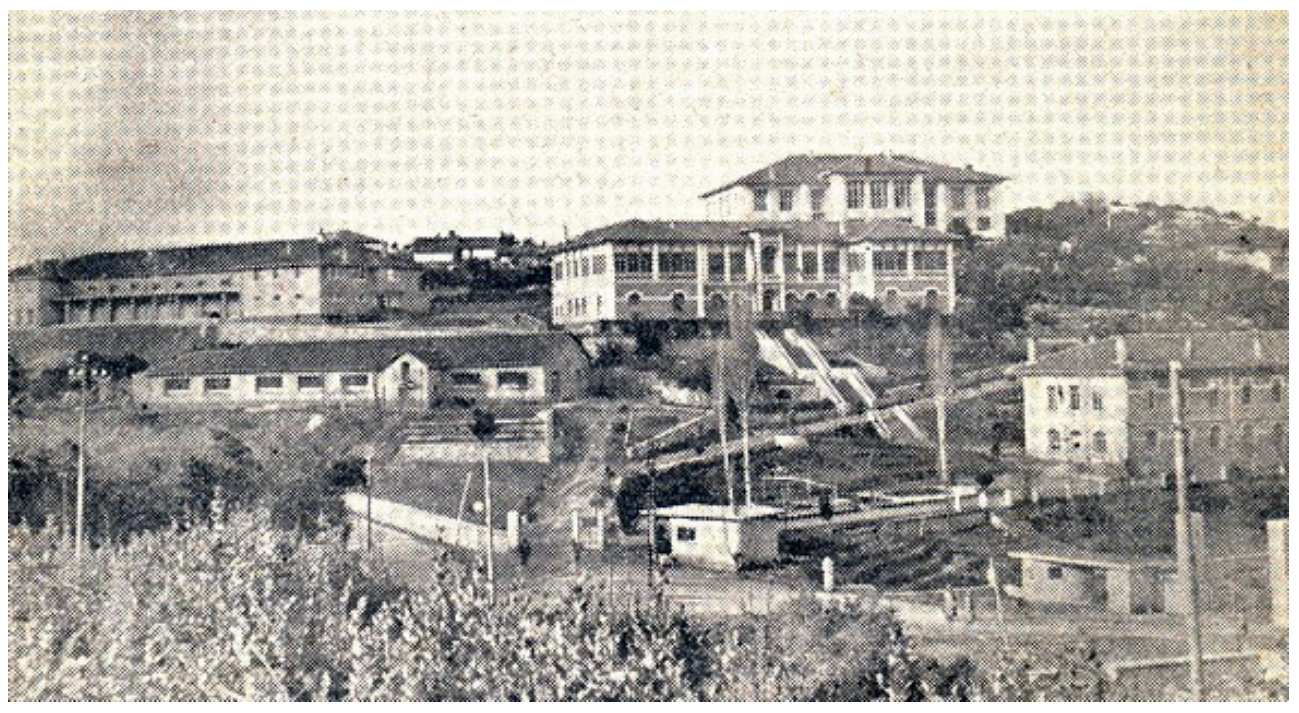

Şekil 21. Zonguldak Maden Teknisyen Mektebi binalarının 1949'daki görünümü. Eski binalara 1942 'de atölye binası ve 1945 'da kapalı spor salonu eklenmiştir.

(Erkek Teknik Öğretim, Ankara: Millî Eğitim Bakanlığı, 1949, 34).

\section{Maden Teknisyen Mektebi ve Spor}

Başta futbol olmak üzere spor 1924'de açılmış olan Maden Mühendis Mektebi'nden itibaren Zonguldak'ta kurulmuş olan bütün madencilik okullarında olduğu gibi Maden Teknisyen Mektebi'nde de önemli bir yere sahiptir. ${ }^{34}$

Yurdumuzun sanayi şehri Zonguldakta bulunan Maden Teknisyen Okulu henüz pek genç yaşında bulunmasına rağmen, çok hummalı bir çalışma ile memlekete teknik elemanlar yetiştirmekte olduğu kadar genç ve gürbüz madenci öğrencilerini okulun önünde bulunan spor sahasında disiplinli ve mükemmel bir sportmen olarak ta hazırlamaktadır. Okulun ayrı ayrı branşlarda muvaffakiyetler kazanmış, halen de her müsabakaya iştirak edebilecek formda futbol, boks, güreş ve atletizm takımları mevcuttur. Okulun geniş spor salonundaki bol ve çeşitli spor malzeme ve takımları öğrencilerin faydalanmasına hazır bulundurulmaktadır.

Okul ilk açılış senesinde Zonguldakta yapılan bütün müsabakalara iştirak etmiş, iyi dereceler almış olduğundan Zonguldak bölgesini temsilen Bursa atletizm birinciliğine

34 “Maden Teknisyen," 314 - 316. 
iştirak eden takıma beş atlet vermiştir. Yine o sene ferdî birinciliklerde Hüseyin Öztek 400 m sürat koşusunda Türkiye birinciliğini kazanarak mektebin spor köşesine şerefli bir bayrak hediye etmiştir.

İkinci sene atlet adedi iki misline çıkmış, bu meyanda diğer branşlarda da çalışma bir misli artmıştır. 19 Mayıs bölge atletizm müsabakasına 25 atletle iştirak edilerek birincilik kupası kazanılmış ve Bursaya giden bölge takımına bu defa altı atlet verilmiştir,

Üçüncü sene mektepte spor hızla gelişerek atlet adedi 50 yi geçmiş 100 - 200 metrede rekorlar kırılmış, $100 \mathrm{~m}$ manialı koşuda mektep rakipsiz kalmıştır.

1944 senesi atletizm müsabakalarında Teknisyen Okulu sahaya kuvvetli bir kadro ile çıkarak okulda sporun şahsa münhasır bir kabiliyet eseri olmadığını, her öğrencinin ayni ciddî önemle spora çalıştırıldığını göstermiştir."

Forması açık ve koyu mavi olan Teknisyen Okulu futbol takımı 1950'de Teknik Spor adı altında birinci amatör kümeye katılmıştır.

\section{Zonguldak Maden Teknik Okulu'nun Kurulması}

\section{Maden Teknisyen Okulu'nun Kapanışı ve Dönüşümü}

1940'lı yılların sonlarına gelindiğinde Maden Teknisyen Okulu'nun Millî Eğitim Bakanlığı'na devri konusu gündeme gelmiştir. Bu konuda 20 Nisan 1948'de verilen kanun tasarısı aradan sekiz ay geçtikten sonra 5284 sayılı "Zonguldak Maden Başçavuş Okulu ile Maden Teknisyen Okulunun Millî Eğitim Bakanlığına devri hakkında Kanun” 27 Aralık 1948'de TBMM'nde görüşülerek kabul edilmişti. [EK 9]. 1 Ocak 1949 tarihinden itibaren yürürlüğe giren bu kanunun 1. maddesi ile "Maden Tetkik ve Arama Enstitüsüne bağlı Zonguldak Maden Başçavuş Okulu ile Maden Teknisyen Okulu, bina ve eklentileri, eşyas1, makine ve aletleri, her çeşit ders gereçleri ve bütün hak ve vecibeleriyle Millî Eğitim Bakanlığına devredilmiştir."

Millî Eğitim Bakanlığı tarafından Başçavuş Okulu kapatılarak bunun yerine Zonguldak Erkek Sanat Enstitüsü’nde bir “Madencilik Şubesi” açılmıştır.

\section{Zonguldak Maden Teknik Okulu'nun kuruluşu}

Maden Teknisyen Okulu'nun Millî Eğitim Bakanlığg'na devrinden sonra okula yeni bir şekil verilmesinin söz konusu olması üzerine büyük çoğunluğu Zonguldak’ta çalışmakta olan bu okuldan mezun maden teknisyenlerinin örgütlenip bir baskı grubu oluşturarak kendilerine mühendis unvanı verilmesi için talepte bulundukları anlaşılmaktadır. Cumhuriyet Halk Partisi Zonguldak milletvekili Sabri Koçer (1909 - 1995) TBMM Başkanlığı'na verdiği bir sözlü soru önergesinde Maden Teknisyen Okulu'nda mühendislik dersleri okutulmasına karşılık 
mezunlarına teknisyen unvanının verildiğini, bu unvanın çok genel olduğunu ve madenlerde çalışan tüm teknik personeli kapsadığını belirterek bu okulun mezunlarına mühendis unvanı verilmesi konusunda ne düşünüldügüunü sormuştur. TBMM'nin 6 Haziran 1949 tarihli toplantısında bu soru önergesini cevaplayan dönemin Millî Eğitim Bakanı Tahsin Banguoğlu ortaokul mezunlarını alan Maden Teknisyen Okulunun kısa bir süre içinde lise mezunlarını alan ve maden mühendisi yetiştiren bir Teknik Okul olarak düzenleneceğini, teknisyenlerin durumlarının bu geçiş döneminde düzenlenebileceğini, 1937'de İstanbul'daki Nafia Fen Mektebi'nin Teknik Okul'a dönüştürülmesinden sonra eski mezunlar için kurslar açılarak bunlara mühendis unvanı verildiğini ve benzer bir uygulamanın da burada yapılabileceğini belirtmiştir. Bu cevaptan tatmin olmayan Sabri Koçer yeniden söz alarak Maden Teknisyen Okulu'nda mühendislik derslerinin okutulduğunu tekrarlayarak mezunlarına doğrudan mühendislik unvanının verilmesini istemiştir. ${ }^{35}$ [EK 10].

Zonguldak Maden Teknisyen Okulu'nun Millî Eğitim Bakanlığı'na devrinden sonra 1949'da yeni öğrenci alınmamış ve aynı yıl maden mühendisi yetiştirmek üzere dört yıllık Zonguldak Maden Teknik Okulu açılmıştır. Teknisyen Okulu'nun ikinci sınıf öğrencileri bu okulun birinci sınıfına ve üçüncü sınıf öğrencileri de ikinci sınıfına aktarılmıştır. Teknik Okul ilk mezunlarını Teknisyen Okulu'ndan gelen öğrencilerle 1951 - 1952 döneminde vermiştir. ${ }^{36}$

Teknik Okul'un açılmasıyla birlikte Teknisyen Okulu mezunları için bir yıllık kurslar açılmış ve bu kursları bitirenlere de maden mühendisi diploması verilmiştir. Teknik Okul'un diploma defterine göre bu kurslardan 1951'de 46, 1952'de 9, 1953'de 16, 1954'de 85 ve 1955 'de 74 kişi olmak üzere 230 kişi mezun olarak maden mühendisi diploması almıştır. ${ }^{37}$ (Şekil 22 ve 23).

35 T.B.M.M. Tutanak Dergisi (Dönem VIII/Cilt 20), 305 - 306.

36 Teknisyen Okulu'ndan Teknik Okul'a aktarılan altı öiğrenci başarısız olmuştur. Millî Eğitim Bakanlığı Talim ve Terbiye Dairesi'nin 15 Ocak 1954 tarihli yazısı uyarınca bu öğrenciler teknisyenlik sınavına alınmışlar ve başarıları üzerine kendilerine "maden teknisyeni” unvanı verilmiştir.

37 Zaman, Kömürün Çocukları, 172. Ancak "Zonguldak Maden Teknik Okulu kurs mezunu mühendislerin listesidir” başlığı altında gerek kendisinin yayınladığı (s. 170 - 171) ve gerekse arşivde bulunan onaylı listelerde 226 kişinin adı bulunmaktadır. [EK 11]. Bu kişilere verilen maden mühendisi diplomalarında normal öğrencilere verilenlerden farklı olarak kurs mezunu oldukları belirtilmiştir. Kurs mezunu maden mühendislerinden 27 kişi ve Teknik Okul mezunlarından da 50 kişi olmak üzere toplam 76 kişi düzenlenmiş olan diplomalarını gelip almadıklarından bunlar günümüze kadar arşivde kalmıştır. 


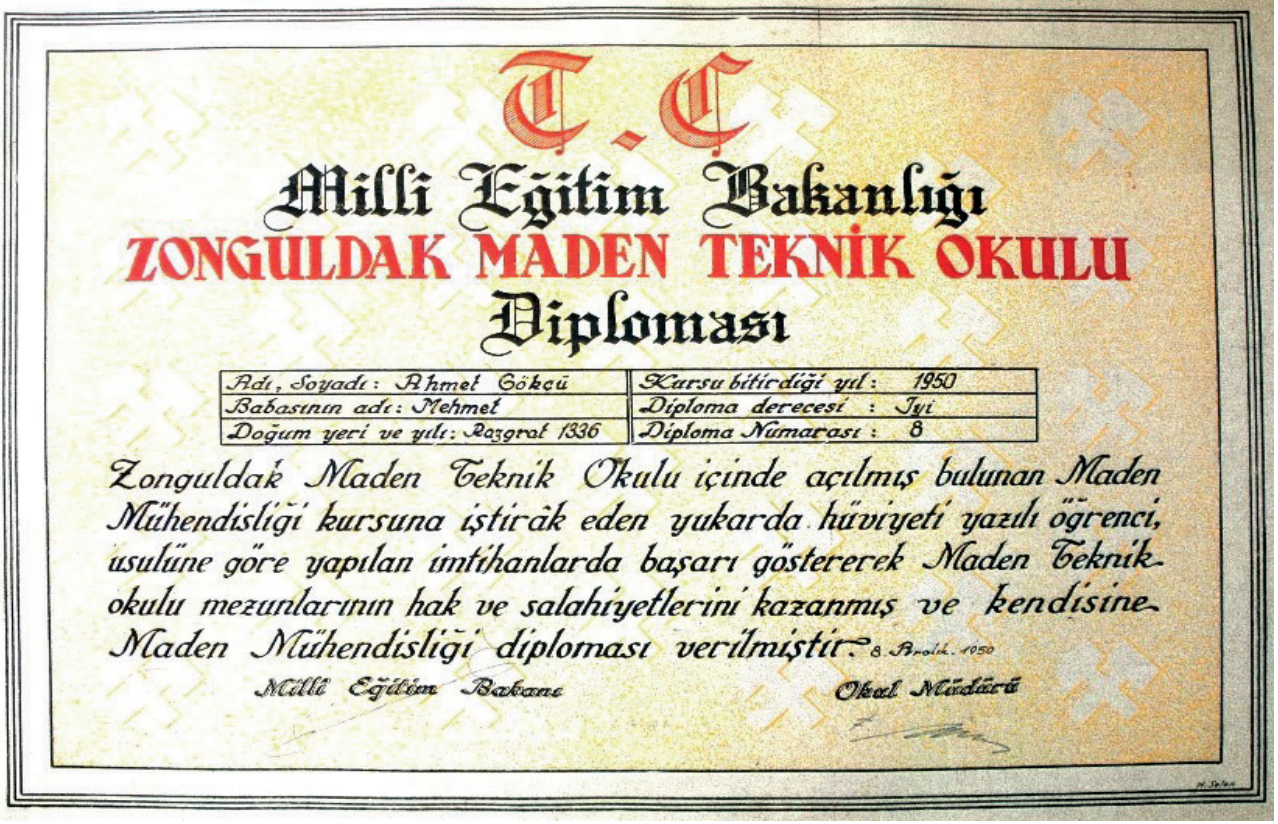

Şekil 22. Aç1lan kursu 1950'de iyi derece ile bitiren Ahmet Gökçü’ye verilen 8 Aralık 1950 tarihli "maden mühendisi" diploması (Zonguldak Maden Teknik Okulu arşivi).

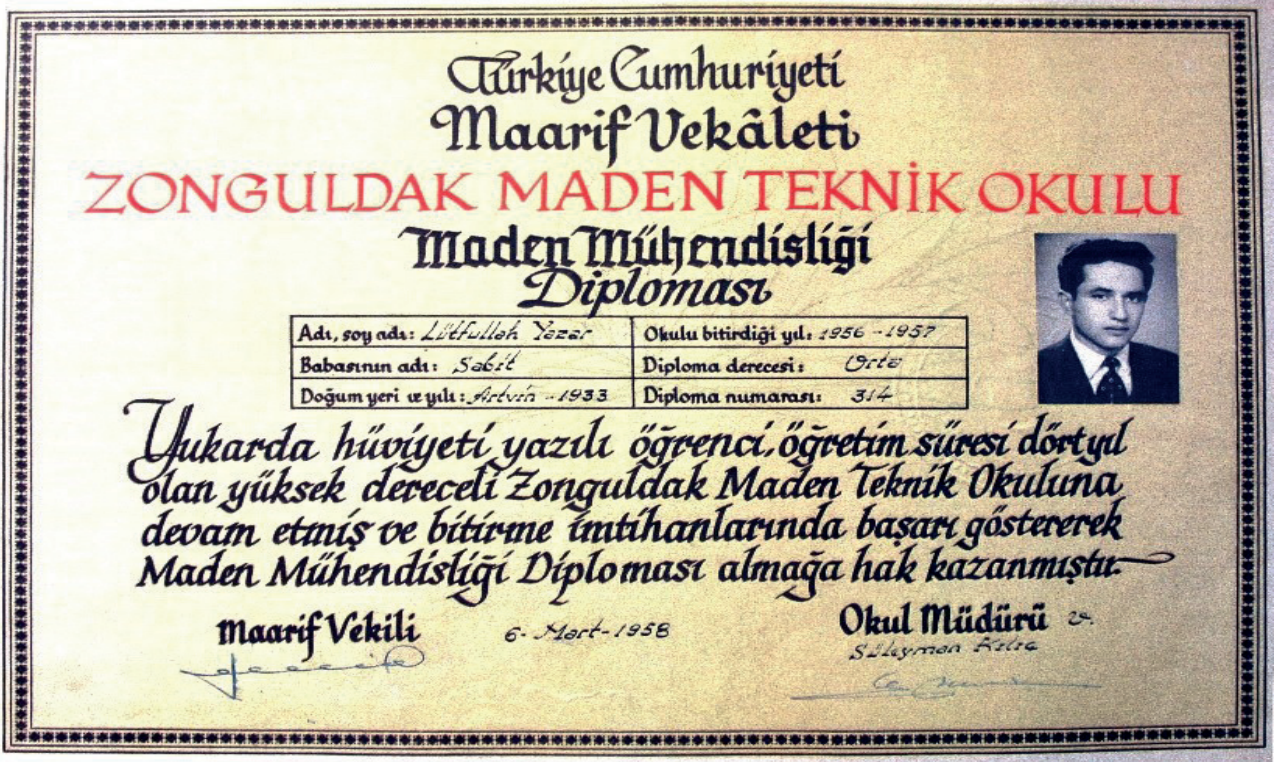

Şekil 23. Maden Teknik Okulu'nu 1956 - 1957 döneminde orta derece ile bitiren Lütfullah Yazar'a verilen 6 Mart 1958 tarihli “maden mühendisi” diploması (Zonguldak Maden Teknik Okulu arşivi). 


\section{Sonuç}

Türkiye'de 1930'lu yılların ortalarından itibaren madenciliğin hızla gelişmesi karşısında gerek mevcut madenlerin işletilmesi ve gerekse maden arama işleri için çok sayıda maden mühendisine ihtiyaç ortaya çıkmıştır. Maden mühendislerine şiddetle ihtiyaç duyulan bölgelerden biri de Zonguldak kömür havzasıdır. Bunun sonucunda maden mühendisliği öğrenimi görmek üzere yurt dışına sürekli öğrenci gönderilmektedir. Bu bakımdan henüz İstanbul Teknik Üniversitesi Maden Fakültesi'nin de açılmadığı bir dönemde maden mühendisi yetiştirmek üzere Zonguldak Maden Teknik Okulu'nun açılması doğrudur. Ancak, madenlerde mühendisten fazla mühendisler ile işçiler arasında görev yapacak değişik düzeyde ara elemanlara ihtiyaç vardır. Bu ihtiyacı karşılamak üzere ilkokul öğrenimi üzerine dayanan Maden Başçavuş Okulu ile ortaokul öğrenimi üzerine dayanan Maden Teknisyen Okulu açılmıştır. Millî Eğitim Bakanlığı bu ara eleman ihtiyacını anlayamamış ve bu okulları derhal kapatma yoluna gitmiştir. Burada bir soru ortaya çıkmaktadır: Bu okullar kapatılsın diye mi Millî Eğitim Bakanlığı'na devredilmiştir?

Millî Eğitim Bakanlığı tarafından yapılan ve siyaseten de desteklenen ikinci hata Maden Teknisyen Okulu'nda okutulan derslerin maden mühendisliği öğretiminde okutulan derslerle aynı olduğu safsatasından yola çıkarak ortaokul mezunu Maden Teknisyen Okulu öğrencilerinin lise mezunlarının alındığı Maden Teknik Okulu'nun birinci ve ikinci sınıflarına aktarılmasıdır. Bazı derslerin adları aynı olmakla birlikte bunların ortaokul mezunlarını alan Maden Teknisyen Okulu'ndaki içerik ve düzeyleri ile mühendislik öğretimindeki içerik ve düzeyleri arasında önemli farkların olduğu açıktır.

Madenlerde ihtiyaç duyulan mühendislerin altındaki ara teknik elemanları yetiştirmek üzere açılan Maden Teknisyen Okulu mezunlarının hemen tümünün kısa sürede mühendise dönüştürülmesiyle beklenen amaca ulaşamamıştır. Maden çavuşu, maden başçavuşu ve maden teknisyeni gibi ara teknik eleman ihtiyacı sürekli olarak varlığını koruduğundan ileriki yıllarda Ereğli Kömürleri İşletmesi tarafından meslek içi eğitim ve kurslarla bu ihtiyaç karşılanmaya çalışılmıştır. 


\section{EK 1}

Yüksek Maadin ve Sanayi Mühendisi Mektebi Maden Meslek Şubesi Talimatnamesi [Yüksek Maadin ve Sanayi Mühendisi Mektebi Talebe Rehberi (İstanbul, 1931), 90 - 91]

1 - Madenlere Jeometir ile Baş çavuş yetiştirmek üzere Yüksek Maadin ve Sanayi Mühendisi Mektebi'nde bir Maden Meslek Şubesi açılmıştır.

Maden Baş çavuşları maden mühendislerinin maiyetinde çalışırlar. Jeometirler, bir madenin dahil ve haricinin haritasını alabilen fen memurlarıdır. Bu iki ihtisas aynı zamanda tahsil edilir.

2 - Bu şube dahi leylî ve meccanî olup tahsil müddeti iki senedir.

3 - Birinci senesine kabul edilmek için,

a. Türkiye tebasından ve hüsnü hal ashabından olmak,

b. 18 yaşından küçük ve 25 ten büyük olmamak,

c. Vücudu madenlerde bilfiil çalışmağa müsait yani gürbüz olmak lâzımdır.

4 - Orta mektep ve ya bu derece mektep mezunları imtihansız kabûl olunurlar.

İlk tahsilden sonra üç sene tahsil edip şehadetname ve ya tasdikname almamış olanlar Hesap [Aritmetik], Müstevi hendese [Düzlem Geometri], Fizik (Cazibe [Çekim]), Hararet [Is1]) ve Kimya (Şibih maadin [Ametaller]) den imtihana kabul olunurlar.

5 - Taliplerin adedi kadroyu geçerse müsabaka imtihanı yapılır.

$\mathrm{Bu}$ imtihanların mahal ve zamanı icrası gazetelerle ilân edilir.

6 - Talebe her sene beş ay ders takip eder, beş ay da madenlerde bilfiil çalıştırılır.

7 - Mektepte atideki dersler tedris olunur:

1 inci senede: Hesap [Aritmetik], Cebir, Hendese [Geometri], Müsellesat [Trigonometri], Fizik, Kimya, Sınaî Mihanik [Mekanik], Madeniyat [Mineraloji], Maadin işletmesi, Resim, Fransızca.

2 inci senede: Arziyat [Jeoloji], Maadin işletmesi, Topografya, Sınaî mihanik, Sınaî elektrik. Resim [Teknik Resim], Fransızca, Maadin kanunu ve zabıtası, Hıfzıssıhhat.

8 - Mezunlar hükümete mecburî hizmetle mükellef değildirler.

9 - Kayıt muamelesi 20 Ağustosa kadar devam eder.

10 - Talip olanlar bir istidaya rapten altı foto, nüfus tezkeresi, tahsil, aşı ve hüsnü hâl şehadetnamesi ile numunesi veçhile bir sıhhat raporunu Zonguldak’ta Yüksek Maadin ve Sanayi Mühendisi Mektebi Müdürlüğüne göndermelidirler.

11 - Maden Meslek Mektebi'ni ikmâl edenler lise şehadetnamesi almadıkça Yüksek Maadin ve Sanayi Şubelerine kabul edilemezler.

12 - Tedrisata 1 Teşrinievvelde [Ekimde] başlanır. Kabûl edilenler 30 Eylül akşamı mektepte bulunmalıdırlar. $\mathrm{Bu}$ tarihte mektebe gelmeyipte mazeretlerini bildirmeyenlerin yerine bir hafta sonra başkaları alınır.

13 - Mühendislik Şubesinin diğer mevadı bu şubeye aynen tatbik olunur. 
EK 2

Maden Tatbikat Mektebi'nin günlük zaman çizelgesi

(Yazarın arşivi)

60niok Iosal progurams

\section{Seat}

$6 . \infty$

$6.00-6.30$

$6.30-7.00$

$7.00-7.30$

$7.30-9.00$

$9.00-9.18$

$0.15-10.00$

$10.00-10.15$

$10.15-I I .00$

II. $00-$ II.IS

II.IS - I2.00

$12.00-00.00$

$12.00-14.00$

$14.00-14.46$

$I 4.45-I 5.00$

$I 5.00-15.45$

$I 5.45 \div I 8.00$

$18.00=19.00$

I9.00-00000

$20.00-2 I .00$

$2 I .00-00.00$

\section{Kalknom}

espinme

kahve alt2

Ist1klal Marge (Wualk1).

atela

renares.

I net Dare

Tenefre:

2 nol Ders

tonerru.

3 net Ders

Yenok

Tenerrus

4 net Dars

Tenerrua

5 nol dere

Tonerrua

intelas

Iomex

natelaa

yatma

$I 7 / 3 / 938$

MODUR 


\section{EK 3}

\section{Zonguldak Maden Başçavuş Mektebi Talimatnamesi}

[Mustafa Nuri Anıl ve Nejdet Merey, Türkiyede Maden Mevzuatı

(İstanbul: Tan Matbaas1, 1942), 2: 28-30]

\section{Mektebin gayesi ve mezunlarının mükellefiyetleri}

Madde - 1: Mektep, maden işletmelerinde lüzumlu görülen amelî ve nazarî bilgiye sahip maden baş̧̧avuşu yetiştirir.

Madde - 2: Mektep mezunları İktisat Vekâletinin göstereceği maden ocaklarında veya mukavele ile bağlı bulundukları işletmeler emrinde beş sene müddetle çalışmağa mecburdur.

\section{Tahsil müddeti ve şekli}

Madde - 3: Mektep leylî ve meccanî olup, talebenin maden ocaklarındaki amelî çalışma devrelerile beraber tahsil müddeti üç senedir.

Her sene, biri amelî, diğeri nazarî olmak üzere iki sömestre ayrılmıştır.

Madde - 4: A : Amelî sömestirler:

a) Amelî sömestirler her sene en az dört aydır. Bu çalışma müddetince talebe madenlerdeki kazancı ile geçinir.

b) Mektep, talebenin amelî sömestirde yapacağ işleri bir programla tayin ederek, çalışacak talebeyi isim ve sınıflarile bir cetvel halinde her devre başlangıcında Zonguldak Mıntaka İktisat Müdürlüğü vasıtasile maden işletmelerine bildirir.

Talebenin çalıştırılacakları maden müesseselerinin alâkadar memurları bu programın tatbikine itina edeceklerdir.

c) Maden işletmeleri, amelî sömestirler esnasında talebeye liyakatlarına göre gündelik tahakkuk ettireceklerse de, asgarî yevmiye birinci sınıf için 100, ikinci ve üçüncü sınıflar için 120 kuruş olacaktır.

Şu kadar ki madenlerden gönderilip mektebe kabul edilmiş olanların, bu talimatname hükümleri fekvinde menfaat teminine matuf ve işletme idarelerile münakit mukaveleleri carî olacaktır.

d) Talebe, maden ocaklarında diğer işçilerin bağlı oldukları şartlara ve iş müddetlerine tâbi tutulacak ve ayrı koğuşlarda yatırılarak gerek mesai, gerek tavır ve hareketleri hususî bir nezaret altında bulundurulacaktır.

e) Amelî mesai sırasında her talebe, çalıştı̆̆ her günün nasıl geçtiğini, o esnada neler yapıp neler öğrendiğini aynı akşam kendi jurnal defterine kaydederek ertesi akşam şefine imzalatmaya, her sömestir sonunda mektebe avdet etmeden evvel jurnal defterini müessese müdürlüğüne tasdik ettirmeğe mecburdur. Bu defterler her sene mektepçe talebe dosyasına konur ve onsuz sınıf geçilmez.

B : Nazarî sömestirler :

a) Birinci, ikinci ve üçüncü sınıfların nazarî sömestirleri 1 İlkteşrin ve 1 Martta başlar, 20 hafta ders ve 2 hafta ders kesimi ve imtihanlar olmak üzere 22 hafta devam eder.

b) Her ders senesi iki devre olup, bu devrelerde mektebe alınacak talebenin adedi M.T.A. Enstitüsünce tayin olunur. 
Madde - 5: Tahsil müddetince ve nazarî sömestirelere münhasır olmak üzere talebeye her ay dört lira cep harçlığı verilir.

Madde - 6: Yalnız birinci sınıf talebesi nazarî sömestrini mektebin Kozlu şubesinde yapar, bu müddet zarfında amele gibi iaşe ve ibate edilir.

Madde - 7: Talebeye her sene için kasketi ile beraber bir takım mektep üniforması ve spor elbisesi, ayakkabı ve bir defaya mahsus olmak üzere palto verilir. Bunlardan maada ocaklarda kullanılmak üzere her sene bir iş̧̧i elbisesi, ayakkabı, üç kat çamaşır, bir pijama, yarımşar düzüne çorap ve mendil verilir.

\section{Alınacak talebe}

Madde - 8: En aşağı 150 gün maden ocaklarında çalıştı̆̆ını tevsik eden ilkmektep mezunları 9 uncu maddede yazılı şeraiti haiz olmak şartile tercihan mektebe alınır ve doğrudan doğruya birinci sınıf nazarî sömestrine başlatılır.

Madde - 9 : Mektebe alınacak talebe aşağıdaki şartları haiz olmalıdır:

a) Türk vatandaşlarından bulunmak,

b) İyi hâl ve ahlâk sahibi olmak,

c) Bulaşıcı hastalıklarla malûl olmamak, sıhhati tam olmak, âzası noksan olmamak, bünyesi tahsile ve madenciliğe elverişli bulunmak,

d) İlkmektep mezuniyet vesikası ibraz etmek,

e) 16 yaşını bitirmiş ve 25 yaşını geçmemiş olmak,

f) Nüfus hüviyet cüzdanı ve dört adet vesika fotoğrafı vermek,

g) Kabul imtihanlarında muvaffak olmak.

\section{Mektepte okutulacak dersler}

Madde-10: A: Birinsi sene :

Türkçe, yurtbilgisi, tarih ve coğrafya, hesap ve hendese, resim ve iş, maden işletmesi ve emniyet dersleri, tabiat bilgisi, sağlık bilgisi ve sıhî yardım, beden terbiyesi, askerlik.

B: İkinci sene :

Türkçe, yurtbilgisi, tarih ve coğrafya, hesap ve hendese tatbikatı, fizik, kimya, teknik resim, teknoloji ve atölye, maden işletmesi, emniyet dersleri, sağlık bilgisi ve sıhhî yardım, beden terbiyesi, askerlik.

C: Üçüncü sene :

Türkçe, cebir ve riyaziye tatbikatı, maden işletmesi, emniyet dersleri, fizik, kimya, teknoloji ve atölye, makine, topografya, jeoloji ve mineraloji, ocak içi inşaat ve tesisatı, meslek terbiyesi, meslekî mevzuat, beden terbiyesi, askerlik. 


\section{Öğretmenler}

Madde - 11: Tedrisat, öğretmenler veya yardımcıları tarafından ifa edilir.

Öğretmenler veya yardımcıları Maden Teknisyen Mektebi tedris heyeti tarafından seçilir ve mektep müdürlüğ̈̈nce inha edilerek M.T.A. Enstitüsünce tayin edilir.

Öğretmen veya yardımcı öğretmenlerin herhangi bir sebeple infisâli hususu tedris heyetinin müteleası üzerine M.T.A. ca kararlaştırılır.

Mütalea saatlerinde talebe ile beraber bulunmak ve kendilerini icap eden mevzularda tenvir etmek öğretmenin veya yardımcı öğretmenin vereceği direktif dahilinde çalıştırmak üzere, her sınıf için ehliyeti tedris heyetince tasdik olunacak bir müzakereci bulundurulacaktır.

\section{Başçavuşluk ehliyet imtihanı}

\section{Madde - 12:}

a) Mektebi muvaffakiyetle ikmal edenler 230 kuruş yevmiye ile ve maden çavuşu sıfatile en az altı ay staj yapmak üzere maden ocaklarına gönderilir.

b) Stajını bitirenler mektebe avdetle, M.T.A. ca teşkil edilecek bir heyet huzurunda sözlü ve yazılı olarak başçavuşluk ehliyet imtihanına tâbi tutulur.

c) Bu imtihanda muvaffak olanlara (Maden Başçavuşu Şahadetnamesi) verilir.

Madde - 13: Maden Başçavuş Mektebi idarî, hesabî, tedrisî ve inzibatî bakımlardan Maden Teknisyen Mektebi esas ve tâlî talimatnamelerine göre idare edilir.

Madde - 14: Elyevm mevcut Maden Tatbikat Kursları, Maden Başçavuş Mektebine kalbedilmiştir. Bu kursların son sınıfı Maden Başçavuş Mektebinin üçüncü sınıfını teşkil edecektir.

Madde - 15: Mektebin derecesinin tayini için bu talimatname Maarif Vekâletince tetkik ve tasdik olunacaktır. 
EK 4

Maden Tetkik ve Arama Enstitüsü'nün Maden Tatbikat (Maden Çavuşu) kurslarına öğrenci alınacağına ilişsin ilânı

(Cumhuriyet, 16 Eylül 1941, 4)

\section{Talebe Alinacak Maden Tełkik ve Arama Enstifuisi Genel Direktörliţ̛̆̈ünden}

Maden caruşu yetiştirilmek ïzere Zonguldak - Kozlu'da leylî ve meccani olarak açilmiş bulunan Maden Tatbikat kurslarina talebe kaydedilmektedir.

Kurslarda tahsil her sene bir ay nazari, bir ayı ameli olmak ve münavebe ile devam etmek ïzere iki sendir.

Kurslara ilk mektep mezunları alinmakta olup, talebe birinci senenin nazarî ve ameli tahsil devrelerinde asgari 100, ikinei senede asgari 120 kuruş yevmiye alacak, mektebi bitirenler maden gavuşu ünvanile en az 230 kurus yevmiye ile işe başlattırilacaktır.

Aşağıdaki şartları haiz olan isteklilerin nihayet 29 eylûl pazartesi akşamına kadar Zonguldakta Maden Teknisyen Mektebi Müdürlü̈̆̈̈ne vesikalarile bizzat müracaatlari lazumdrr.

1 - Tük vatandaşı olmak

2 - tyi hal ve ahlâk sahibi oldư̆anu tevsik etmek

3 - Bulaşıcı hastalıklarla malûl olmamak, bünyesi maden ecaklarinda ameli çalıgmaya müssait bulunmak "sihhi muayene Zonguldakta yapulacaktır..,

4 - Ilk mektep mezuniyet resikasın ibraz etmek

5 - Dört adet vesika fotoğrafı rermek

6 - 16 yaşını bitirmiş 25 yaşını geçmemiş olmak.

'6610" "8176" 
EK 5

Maden Başçavuş Mektebi öğrencilerine 1941 - 1942 yıllarında verilen çamaşır ve elbise listesi

[Maden Başçavuş Mektebi arşivi]

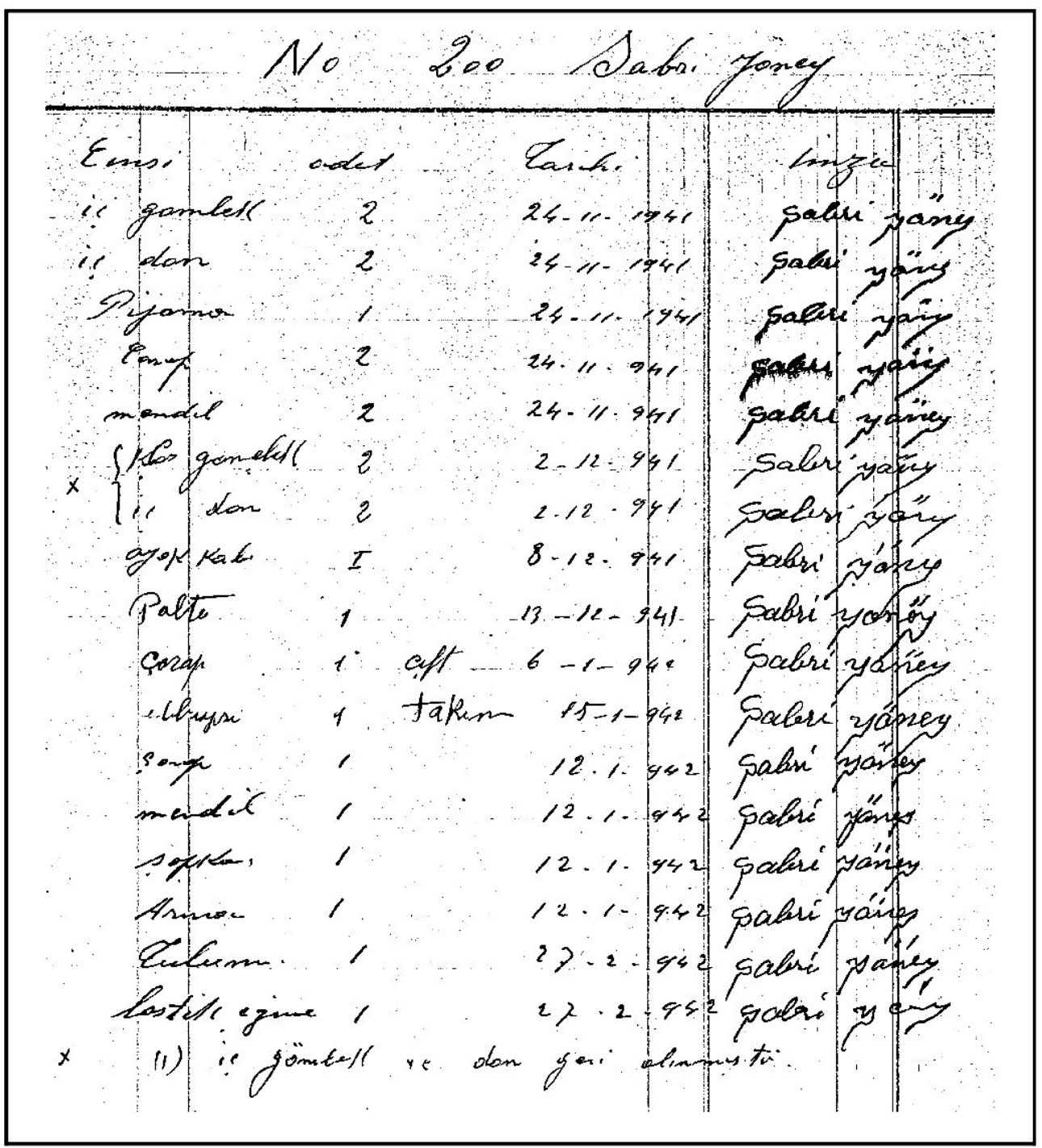




\title{
EK 6
}

\author{
Zonguldak Maden Teknisyen Mektebi Esas Talimatnamesi \\ [Mustafa Nuri Anıl ve Nejdet Merey, Türkiyede Maden Mevzuatı \\ (İstanbul: Tan Matbaas1, 1942), 2: 19 - 27]
}

\begin{abstract}
Mektebin gayesi
Madde - 1: Mektep, maden ocaklarında ve maden sanayii işletmelerinde çalışacak, nazarî ve amelî bilgilerle mücehhez teknisyenler yetiştirir.

Madde - 2: Mektep mezunları, İktisat Vekâletinin göstereceği mahallerde ve maden sanayii işlerinde beş sene müddetle çalışmağa mecburdur.
\end{abstract}

\section{Tahsil müddeti ve şekli}

Madde - 3: Mektep leylî ve meccanî olup talebenin maden ocaklarındaki amelî çalışma devresile beraber tahsil müddeti dört senedir. Her sene biri nazarî, diğeri amelî olmak üzere, iki sömestre ayrılmıştır.

A - Nazarî sömestreler :

a) Birinci, ikinci, üçüncü sınıfların nazarî sömestreleri 1 İlkteşrin ve 1 Martta başlar, yirmi hafta ders ve 2 hafta ders kesimi ve imtihanlar olmak üzere 22 hafta devam eder.

b) Dördüncü sınıf nazarî sömestri 4 hafta ders kesimi ve imtihana ayrılmak üzere 42 haftadır.

c) Her ders senesi iki devre olup, bu devrelerde mektebe alınacak talebenin adedini İktisat Vekâleti tayin eder.

B - Amelî sömestreler :

a) Her sene en az dört aydır. Bu çalışma müddetince talebe madenlerde ve maden sanayii işletmelerindeki kazancı ile geçinir.

b) Talebenin amelî sömestrede yapacağı işleri mektep bir proğramla tayin ederek, çalışacak talebeyi isim ve sinıflarile birlikte bir cetvel halinde her sene Şubat ve Ağustos ayları içinde Zonguldak İktisat Müdürlügüne bildirir. İktisat Müdürü ise, amelî çalışma yerlerini her talebe için ayrı olmak üzere, alâkadar müesseselerle kararlaştırarak Mart ve Eylûl nihayetlerine kadar mektebe iblâğ eder. Talebenin çalışmakta bulundukları müesseselerin alâkadar memurları bu programın tatbikine itina edeceklerdir.

C - Amelî sömestreler esnasında müesseseler talebeye liyakatine göre günlük tahakkuk ettirecekse de asgarî yevmiye 120 kuruş olacaktır.

D - Müessese idareleri, amelî sömestreler esnasında talebenin devamını takip ve hususî bir deftere kaydederek bu kuyudatı beş sene muhafaza etmeğe mecburdurlar.

E - Her talebe, çalıştığı her günün nasıl geçtiğini, o esnada neler yapıp neler öğrendiğini, ayni akşam kendi jurnal defterine kaydederek ertesi akşam şefine imzalatmaya, her sömstr sonunda mektebine avdet etmeden evvel jurnal defterini müessese müdürlüğ̈ne tasdik ettirmeğe mecburdur. Bu defterler her sene mektepçe talebe dosyasına konur ve onsuz sınıf geçilemez. 
F - Talebenin her sene sınıf geçmesi her iki sömestr çalışmasından alınacak neticeye göre taayyün eder. Amelî sömestrede muvaffak olamıyan veya müddetini dolduramıyan talebe nazarî sömestrede ne şekilde muvaffak olursa olsun sınıf geçemez.

G - Tahsil müddetince ve nazarî sömestrelere münhasır olmak üzere talebeye her ay 6 lira cep harçlı̆̆ verilir.

\section{İmtihanlar}

Madde - 4: Her ay sonunda talebe bütün derslerden tahrirî yoklamaya tâbidir. Sualler yalnız o ayın tedrisatına ait olmayıp daha evvel okunan bahislere de şamil olabilir. Umumî imtihanlar sömestr nihayetinde icra olunur. Yoklama imtahanlarında her dersten alınan notların vasatîsi ile ayni derslerden umumî imtihanda alınan notların iki misli cemedilerek üçe taksiminden çıkan harici kısmet o derslerin nazarî sömestr numarasını teşkil eder.

Madde - 5: Meşru bir mazerete binaen tahrirî yoklamalarda veya umumî imtihanda bulunmamış olan talebe bilâhare ayrıca tahrirî yoklamaya ve amelî sömestrelerini ikmâl ettikten sonra da umumî imtihana tâbi tutulurlar.

Madde - 6: Tam numara 10 dur ve aşağıdaki şekilde beş derece üzerine verilir.

$$
\begin{gathered}
10-\text { Çok iyi } \\
9-8 \text { İyi } \\
7-6 \text { Orta } \\
5-\text { Zayıf } \\
4-0 \text { Fena }
\end{gathered}
$$

Küsurlu numara yoktur, vasatîlerde yarım numara talebe lehine kaydedilir, yarımdan az numara nazarı itibara alınmaz. Vasatî numarası 6 yı tutmayanlar sınıf geçemez. Derslerin umumî vasatisi orta tutarsa fena numaralı derslerden talebe ikmale kalır. Birinci, ikinci, üçüncü sınıflarda cem'an iki defa sınıf geçemiyen talebe mektepten ihraç edilir.

Madde - 7: Nazarî her sömestr zarfinda devam nisbeti 2/3 tür. Hastalıkla dahi olsa, bundan az devam eden talebe imtihana giremez ve sinıf geçemez.

Madde - 8: Mezuniyet imtihanı için, her dersin muallimi ve İktisat Vekâleti tarafindan seçilecek iki mümeyyiz huzurunda imtihanlar yapılır. Mektepten mezun olabilmek için her talebenin her dersten bu şekilde sözlü ve yazılı imtihanlarda muvaffak olması şarttır.

Her dersten asgarî altı alanlar muvaffak olmuş sayılırlar. Derslerin umumî vasatisi orta tutmak şartile altıdan aşağı numara aldığı dersten talebe ikmal imtihanına tâbi tutulur. Son sınıfta ikinci defa muvaffak olamayan talebenin mekteple alâkası kesilir.

Madde - 9: Mektebi ikmâl edenlere "Maden Teknisiyeni” ünvanı verilir.

Madde - 10: Mektepte umumiyetle riyaziye, mihanik, fizik, kimya, jeoloji, mineraloji, maden işletmesi, elektromekanik, makine, topografya, tahlisiye ve ilk yardım, yapı işleri, maden ve iş mevzuatı, maden iktisadiyatı, maden sanayii muhasebesi, sağlık bilgisi, lisan gibi dersler gösterilir. 


\section{İdare şekli}

Madde - 11: Mektep, bir mütehassis müdürün idaresine tevdi olunarak, bu esas talimatnameye ve yapılacak diğer talimatnamelere göre idare olunur. Müdürün bir muavini vardır.

Madde - 12: Mektebin tedris kısmını, tedris meclisi, muallim ve muavin, lâboratuvar şefi, atölye şefi ve diğer teknik memur ve müstahdemler teşkil eder.

Madde - 13: Mektebin idare kısmı, idarî ve hesabî işleri ifa etmekle mükellef memur ve müstahdemlerle idare ve inzibat heyetlerinden ibarettir.

\section{Tedrisat}

Madde - 14: Tedris meclisince tanzim ve M.T.A. ca tasdik edilecek müfredat ders programlarına göre icra edilir.

Madde - 15: Tedrisat müdürün idare ve bakımı altında olmak üzere muallim ve muavinler tarafindan yapılır.

Madde - 16: Tedrisat; ders takriri ve müzakeresi, tatbikat yaptırılması, resim ve proje tanzimi, lâyiha kaleme alınması, el işçiliği, lâboratuvar ve atölye çalışmaları, zemin üzerinde ameliyat, fabrikalar ve maden sanayii müesseselerinin ziyareti, fennî seyahatler yapılması suretile ifa olunur. Muayyen kitabı olmayan derslerin muallimleri okuttukları dersi makine ile mumlu kâğıt üzerine basılmış ve teksir edilmiş olarak talebeye dağıtırlar.

Madde - 17: Muallimler kendi derslerine ait lâboratuvar, atölye ve müzenin âmirleridir. Muavinlerle diğer teknik memurlar talimatnamelerine tevfikan tedrisatın icra ve idaresinde muallime yardımla mükelleftirler.

\section{Muallim ve muavin olabilmek şartları}

Madde - 18: Muallim olabilmmek için :

En az Yüksek Mühendis Mektebi veya bu derecede bir meslek mektebinden mezun olmuş veya okutacağı dersin istilzam ettiği yüksek tahsili görmüş ve Maarif Vekâletinin öğretmenlerden aradığ kanunî evsafi haiz bulunmak ve devlet mevzuatınca kabul edilmiş en az bir ecnebi lisana vâkıf olmak şarttır. Yalnız meslekî olmayan umumî derslerin muallimlerile muavinler bu kayıttan M.T.A. ca istisna edilebilir. Müsavi şartlar altında muallimliğe tercihan muavinler seçilir. Türk muallim bulunmayan ihtisas derslerine mukavele ile yabancı muallim alınır.

\section{Muallim ve muavinlerle lâboratuvar ve atölye şeflerinin intihap ve tayinleri}

Madde - 19: Muallim ve muavinlerle Lâboratuvar ve Atölye Şefleri tedris meclisi tarafindan seçilirler ve M.T.A. Genel Direktörlügünce tayin olunurlar. İşbu tayinler İktisat Vekâletinin tasdikile tekemmül eder.

Madde - 20: Muallimler ve muavinler arasında her hangi birinin vazifesinde müsamahas1, muvaffakiyetsizliği veya hâl ve hareketinde mektebin ve mesleğinin şeref ve haysiyetini muhil bir hali görülürse müdürün teklifi üzerine tedris meclisi kararile istifaya davet olunur. Tedris meclisi istifaya davet kararını alâkadarların yazılı veya sözle müdafaasını dinleyip anladıktan sonra mürettep âzasının dörtte üç ekseriyetile ittihaz eder. Alâkadar istifa etmediği takdirde mesele M.T.A. ya bildirilir. M.T.A. Genel Direktörlügünün vereceği ve İktisat Vekâletinin tasdik edeceği karara göre hareket edilir. 


\section{Tedris meclisi}

Madde - 21: Tedris meclisi muallimlerden teşekkül eder.

Madde - 22: Meclise, muallimler arasından intihap edilen zat reislik eder ve Müdür muavini tedris meclisinin tabiî âzası ve umumî kâtibidir.

Madde - 23: Tedris meclisi tatil devresi müstesna olmak üzere en az ayda bir defa toplanır. Aylık toplantı günleri her tedris yılının ilk ayında içtima edecek mecliste tesbit olunur. Bu ilk toplantı müdürün daveti ile ve diğer toplantılar davetsiz yapılır. Aylık toplantıdan başka yapılmasına lüzum görülen toplantılar, ya meclisin gününü tayin ederek vereceği karar veya reisin en az üç gün evvel vaki olacak daveti üzerine yapılır. Mürettep âzanın dörtte biri tarafindan yazı ile talep vukuunda reis meclisi toplantıya çağırmağa mecburdur. Meclisin toplantıya çağırılması yazı ile ve yazıya müzakere ruznamesinin derci suretile vaki olur.

Madde - 24: Tedris meclisi toplantılarını mektepte yapar. Müzakerelerin muteber olabilmesi, mürettep âzanın yarısından bir fazlasının toplantıda hazır bulunmasına bağlıdır. İçtimada nisabı müzakere hasıl olmazsa üç gün sonra yeni bir içtima yapılır. Mazeretsiz devam etmiyenler hakkında yirminci madde hükmü tatbik olunur.

Madde - 25: Tedrisat Meclisi kararları hazır bulunan âza reylerinin ekseriyetile verilir. Reylerde denklik halinde reisin bulunduğu taraf üstün sayılır.

Madde - 26 - Her toplantıya ait zabıtnameler deftere geçirilir ve toplantıda hazır bulunan âza tarafından imza edilir. Bu suretle tasdik edilmiş ve imzalanmış olan zabıtnamelerin musaddak birer sureti müdürlükçe her ay nihayetinde M.T.A. ya gönderilir.

Madde - 27: Müdür, tedris meclisi kararlarını tatbika ve M.T.A. Genel Direktörlügüne bildirilmesi icap edenleri bildirmeğe mecburdur.

Madde - 28: Tedris meclisi aşağıdaki işleri yapar :

A - Mektebin tedrisatına müteallik talimatnamelerin yapılması ve değiştirilmesi,

B - Derslerin muhtelif sınıflara tevzii ve lüzum görüldükçe ders konması ve kaldırılması,

$\mathrm{C}-$ Muallim ve muavinler kadrosunun tanzimi

D - Lâboratuvar ve atölye şeflerile muallim ve muavinlerin seçilmesi,

E - Tahsilini bitiren talebeye şahadetname verilmesi,

F - Tedrisata müteallik olmak üzere lüzum görülecek diğer mevzuların konuşulması.

Bunlardan A, B, C, D, E fikralarındaki hususlar M.T.A. nın tasdikile tamam olur.

\section{İdare}

Madde 29 - Müdür, mesleğinde iyi tanınmış yüksek mühendislerden olmak üzere M.T.A. ca inha ve İktisat Vekâletince tayin olunur.

Madde - 30: Müdür, Mektebin en büyük âmiri olup, umumî idare ile bütün muamelelerin merciidir. Müdür, M.T.A. dan verilen emirlerin ve tedris meclisince ittihaz edilen kararların icrasını temin eder. 
Madde - 31: Müdür muavini de kabil olduğu takdirde yüksek mühendisler arasından intihap ve müdür gibi tayin olunur. Müdür muavini mektebin bilûmum idare ve tedris işlerinde müdürün emri altında iş görmek ve ona yardım etmekle mükelleftir. Müdürün bulunmadığı zamanlarda mektebe ait bütün işleri müdür namına tedvir eder. Müdür ve muavini hariçte iş alamaz.

Madde - 32: Mektebin hekimi talebenin sağlık sicillerini tutar. Talebe, memur ve müstahdemleri tedavi ve mektep revirini idare eder. Hekim mektebin sağlık şartlarına bakmağa mecburdur.

\section{İdare heyeti}

Madde - 33: İdare heyeti müdür ve muavini ile muhasip ve idare âmirinden terekküp eder. İdare heyeti müdürün daveti üzerine içtima eder, mukarrerat ekseriyetle ittihaz olunur, mukarrerat defterine kayit ve imza edilir.

Madde - 34: İdare heyetinin vazifeleri şunlardır :

a) Mektebin her türlü ihtiyacını tesbit etmek,

b) Mübayaa olunacak eşyanın nümunelerini tayin ve hıfzetmek,

c) Mübayaa olunan eşyayı, hini vürudunda muayene ve nümunesine tatbik ve tesellüm etmek,

d) Levazım memuru tarafından alınan eşyaları kontrol ve muayene ve icabında bu hususa âzadan birisini memur etmek,

e) Mektebin bilûmum demirbaş eşya ve levazımından, istimalden sakıt veya hasara duçar olanları tetkik ve icap eden mazbataları tanzim etmek,

f) Her ay nihayetinde veya lüzum gördükçe eşya ve erzak anbarlarını teftiş ve anbarlarda mevcut eşya ve erzakı tartmak, saymak ve anbar levazım defterini teftiş ve kontrol ve bu hususta tanzim kılınacak müşterek zabitnameyi imza etmek,

g) Mektebe ait bilûmum sarfiyatın senedat bordrolarını tasdik etmek.

\section{Inzibat heyeti}

Madde - 35: İnzibat heyeti müdür veya muavini ile üç muallimden teşekkül eder. Bu üç muallim her sene başlangıcında tedris meclisi tarafindan intihap olunur. İnzibat heyeti, müdürün daveti üzerine içtima eder. Mukarrerat reylerin ekseriyeti ile ittihaz olunarak karar defterine kayıt ve imza edilir. Reyler denk geldiğinde müdürün bulunduğu tarafin reyi mer'i olur.

Madde - 36: İnzibat heyeti :

Mektebin inzibat işlerine dair müdür tarafından havale olunan bilûmum evrakı tetkik ile karar verir, kat'i tard cezaları M.T.A. tasdikile tekemmül eder.

\section{Talebe}

Madde - 37: Talebe ancak tahsile devamına mâni sıhhî bir manii bulunduğu bir heyeti sıhhiye raporile tevsik edildiği takdirde M.T.A. nın tasvibile mektebi terkedebilir. Talebe bundan maada bir sebeple tahsili terkedemez. 
Talebeden veya velisinden veyahut vasisinden mecburî hizmetini ifa etmediği veya tahsilde iken mektebi terkettiği veyahut mektep talimatnameleri mucibince kaydı terkin edildiği takdirde tahsil müddetince kendilerine yapılan masrafi faizi ile birlikte ödeyeceklerine dair noterden tasdikli bir taahhütname alınır.

Madde - 38: Talebe mektebin zaptu rabt ve intizamına ve bunlara ait talimatnamelere tamamen riayet eylemek, âmirlerine ve muallimlerine daima hürmet ve itaat etmek, derslerine muntamazan devam eylemek ve çalışmak, arkadaşlarına karşı terbiye ve nezaketle muamele etmek, velhasıl her hususta salim ve dürüst bir hattı hareket takip eylemek vazifesi ile mükelleftir.

Madde - 39: Talebe her yerde şeref ve haysiyetini vikaye ve muaşeret âdabına riayet eder. Daima temiz ve muntazam bir kıyafette gezer. Kendisine tahsis edilen yeri ve emanet olunan eşyayı hüsnü muhafaza eyler.

Madde - 40: Mektebe alınacak talebe aşağıdaki şartları haiz olmalıdır :

A - Türk vatandaşlarından bulunmak,

B - İyi hal ve ahlâk sahibi olmak,

C - Bulaşıcı hastalıklarla malûl olmamak, sıhhati tam olmak, âzası noksan olmamak, bünyesi tahsile ve madenciliğe elverişli bulunmak,

D - En az ortamektep tahsilini veya bir sanat mektebini bitirmiş olmak, veya liseye girmek hakkını veren bir vesikayı ibraz etmek,

$\mathrm{E}-18$ yaşını bitirmiş ve 25 yaşını geçmemiş olmak,

F - Kabul imtihanlarında muvaffak olmak.

Madde - 41: Tedrisatın başladığı tarihten itibaren makul mazereti olmaksızın bir ay müddetle mektebe devam etmiyenlerin kayıtları silinir.

Madde - 42: Mektebin tatil günleri şunlardır :

A - Resmî günler ile her cumartesi öğleden sonra Pazar akşamına kadar hafta sonları,

B - Memlekette veya mektepte sarî hastalık zuhurunda sıhhat müdürlüğünce kararlaştırılan günler.

Madde - 43: Talebenin sıhhî durumu her iki ayda bir umumî muayeneye tâbidir ve bu vaziyet talebenin sıhhî durumu hakkında tutulacak defterine her talebe için ayrı ayrı kaydolunur.

Madde - 44: Gerek hastalık ve gerek istirahat dolayısile mektepte kalması muvafik görülmiyecek talebeye sıhhî teşkilâtın lüzum gösterdiği müddetçe mezuniyet verilir.

Madde - 45: Talebenin ilbas ve iaşesi aşağıda gösterildiği şekilde yapılır :

A - Talebeye her sene için kasketi ile beraber bir takım mektep üniforması ile spor elbisesi, ayakkabı ve iki senede bir olmak üzere bir palto verilir. Bundan maada ocakta kullanılmak üzere her sene bir işçi elbisesi, ayakkabı, altı kat çamaşır, yarımşar düzüne çorap ve mendil verilir.

B - Öğle ve akşamları ikişer kap yemek verilecek ve haftada ayrıca iki defa tatlı ve bir defa da börek ilâve edilecektir. Kuru veya yaş meyva tatlı yerine verilebilir. Bundan başka sabah kahvaltılarında çayla beraber peynir veya zeytin verildiği gibi, bunlar yerine çorba da verilebilir. 
C - Talebenin iaşe tabelâsına dahil olabilecek memur ve müstahdemler M.T.A. ca tesbit olunur.

Madde - 46: Talebe muallimi refakatinde olarak maden ocaklarını ziyarette veya fennî tetkik seyahati yaptıklarında iaşeleri tutarı olan bedel ya kendilerine verilir veyahut bu bedel ile mezkûr mahalde iaşeleri temin olunur.

\section{Cezalar}

Madde - 47: Talebeye verilecek cezalar şunlardır :

A - İhtar (Müdür tarafindan yapılır).

B - Tekdir (Müdür tarafından yazı ile yapılır).

$\mathrm{C}-$ Muvakkat tard (İnzibat heyeti tarafindan verilir).

D - Kat'î tard (M.T.A. tarafından verilir).

Madde - 48: Bu talimatnamede yazılı olmayan hususat devlet mekteplerinde carî olan ahval ve şerait nazarı itibara alınarak M.T.A. ca kararlaştırılıp tatbik edilir.

\section{Mükâfatlar}

Madde - 49: Nazarî ve amelî mesaileri esnasında hüsnü hali ve muvaffakiyeti görülen talebeye tedris heyeti kararile ocak ve işletmelerde kazandığı ücretin yüzde yirmisine kadar nakdî mükâfat verilebilir.

Madde - 50: Mübrem ihtiyacı mektep idaresince kabul edilen talebeye yardım için mektepte bir yardım sandığı ihdas edilecektir. Bunun talimatnamesi M.T.A. ca hazırlanır ve İktisat Vekâletince tasdik olunur.

\section{Muvakkat hükümler}

Madde - 51: İlk tedris heyeti M.T.A. ca intihap ve Vekâletçe tayin olunur.

Madde - 52: Mektebin her sene başında kadrosu ile bütçesi, mektep müdürlügünce tanzim ve İkincikânunun 15 ine kadar berayı tasdik M.T.A. yolile İktisat Vekâletine arzolunur.

Madde-53: Mektebin muhasebe talimatnamesi ile tedrisat, inzibat ve dahilî talimatnamesi bu esas talimatname dairesinde M.T.A. ca yapılır.

Madde - 54: Mektebin derecesinin tayini için bu talimatname Maarif Vekâletince tetkik ve tasdik olunacaktır. 
EK 7

Maden Teknisyen Mektebi müdür ve müdür muavinliği görevlerinin "ihtisas mevkii olarak tayini” hakkında 14 Mayıs 1941 tarih ve 2/15771 sayılı kararname

(BCA, Fon kodu: 30.18.1.2/Yer No: 95.40.6)

T. C.

BASVEKALET

KARARLAR DALRESI MUDUEHOCO

Kerar wones

$\frac{2}{15 \times 71}$

\section{Kararname}

H.T.A. Thstituss teşkilotine dasil Zontuldak hieden teknisijen mektebi lindur ve undür ravinlicóci vazifele rinir intisas wevkii olerak tayini; Ikt lsat Vekilliginin $9 / 4 /$ To4I tarin ve $I$ / I356 sayll tezkere-

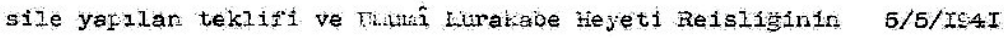
tarih ve 564 sayll miltaleanenusi uzerine, 3650 sayılı kanunun 9 uncu natalesine tevfikan, Icra Vekilleri Hejetince 14 Hays 1941 tarininoe kabuz olunmustur.

Rg士3 ICUALUR

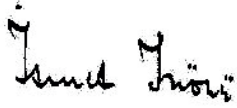
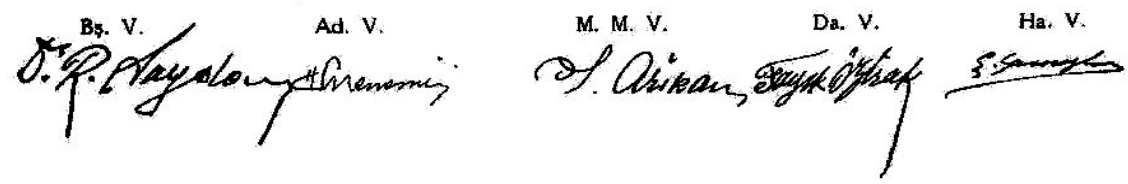

Ha. V.
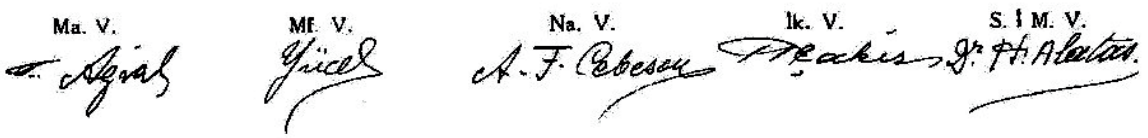

G. I. V. zr. v.

Mŭ. V.

Ti. V.

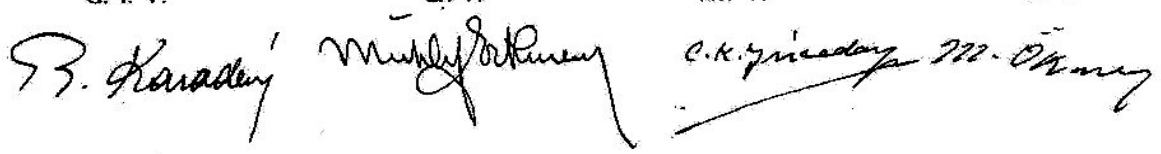


Emre Dölen

EK 8

Maden Teknisyen Mektebi'nin derslerinin sınıflara dağılımını gösteren not (Zonguldak Maden Teknisyen Mektebi arşivi)

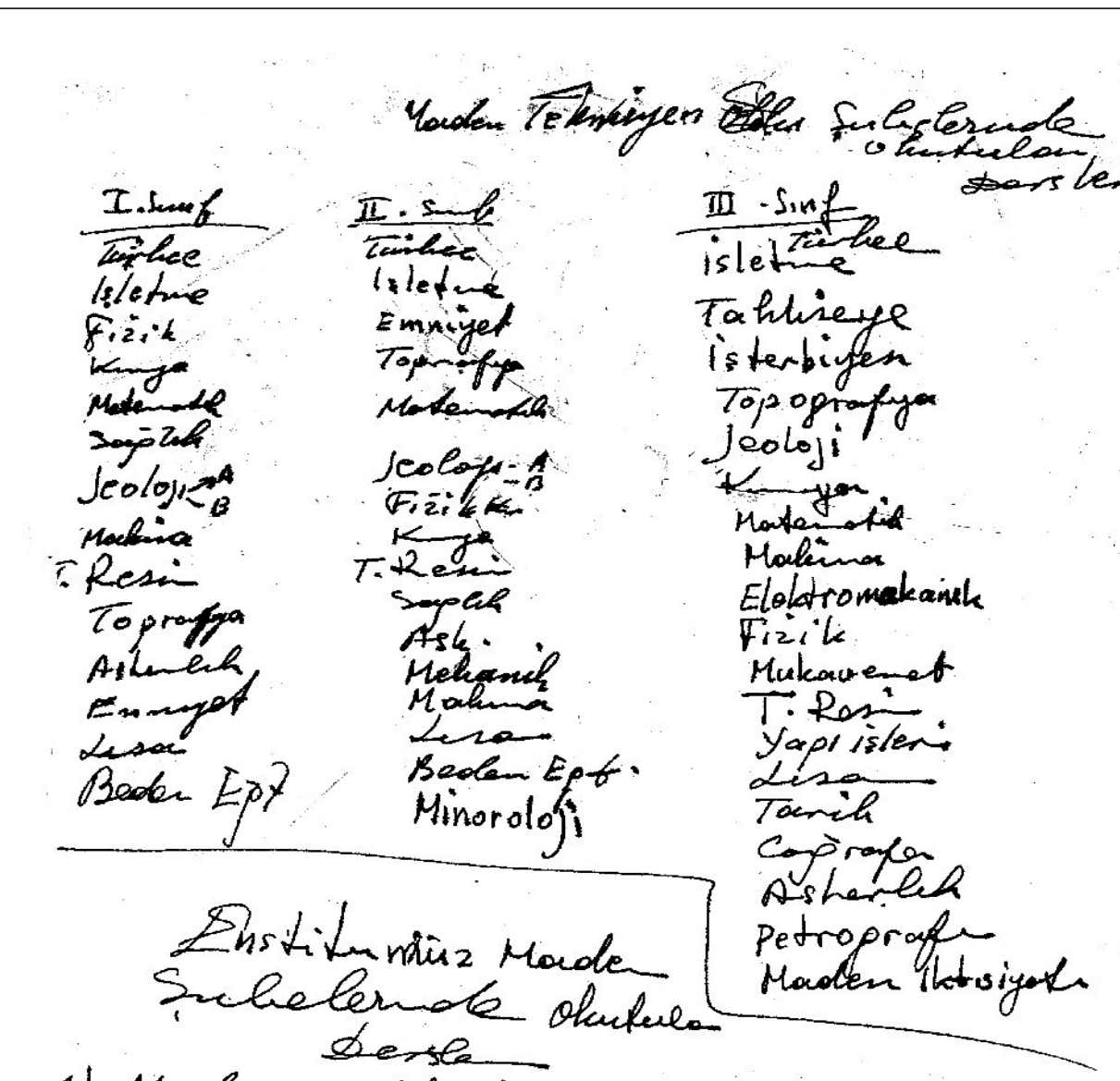

1) Maden piesteh Tehrologe:

2) Maden is letwenive Kathehate

$3)$ T Topoprafly we Tathenat

4) $\operatorname{eologi}$

Osmanlı Bilimi Araştırmaları 22, 1 (2021)

57 
EK 9

Zonguldak Maden Başçavuş Okulu ile Maden Teknisyen Okulu'nun Millî Eğitim Bakanlığı'na devri hakkında 21 Aralık 1948 tarih ve 5284 sayılı kanun

(Düstur, 3. Tertip, 30: $80-82$ ).

\section{No: 32 - Zonguldak Maden Başavus Okulu ile Maden Teknisiyen Okulunun Milli Eğitim Bakan- liğma devri hakkrnda: Kanun}

Kabul tarihi: 27 Aralik 1948

[Resmt Gazete ile yayım ve ilam: 29 Arahk 1948 - Sayn: 7092]

Kanuir No: 5284

Madde 1 - Maden Tetkik ve Arama Fnstitüsüne bağli Zonguldak Maden Baş̧arus Okulu ile Zonguldak Maden Teknisiyen Okulu, bina ve eiclentileri, esyast, makine ve aletleri, her çsit ders gerecleri ve bitil hak ve vectbeleriyle Minf Hgitim "Bakanlı̈̆na devredilmistir.

3460 sayil kanunun 45 incl maddesi bu okwllarda bgretmentlk Japacak uzman memurlar hakkinda uygulanmaz.

Madde 2 - Bağli (1) sayil cetvelde derece, ğörev, sayı ve aylıkłarı yazll kadrolar, Mull Fogitim Bakanliğ kurulus kadrolariyle merkez kurưluşu ve görevleri hakkındalk 2287 sayılı kanunda değłşłklik yapilmasına dair olan 10/6/1946 tarthll ve 4926 sayll kanuna bagh (1) sayll cetveHn (VI) nci (Meslekd ve Teknlk Ofretim dairelerine bagh okullar ve gobrevler) kiamma ve bağh (2) aayll cetvelde gorev, sayn ve ticretlerl yazh ek görev tazminatı kadrolar da ayn januna bağli (2) saynl cetvelin

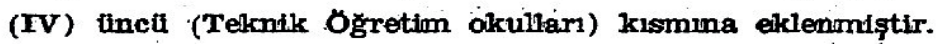

Milli Efoltim Bakamilg1 yulkarda yazll ayliklı kadralara bu kanunun yururlüge girdigl tărlhte adi geçen okul kadrolarinda, görevli bgrretmenienden dilediklerini 16/3/1936 tarihli ve 2919 sayli kanunun 4 tincä maddesine dayamilarak kadio dı̧̣ şalışturulmakta olan stajyerlere tercihan tayin edebillir.

Madde 3 - Bu kanuin 1 Ocalk 1949 tarthinde ylururlagge girer.

Madde 4 - Bu kanunu Maliye, Milli Egritim ve Ekonoml Bakanları yürütïr.

$$
28 / 12 / 1948
$$

Kanun tasarisinin verilme tarihi: 20 Nisan 1948

Gorräsime tarihi

: 27 Aralık 1948 
EK 9

(Devam)

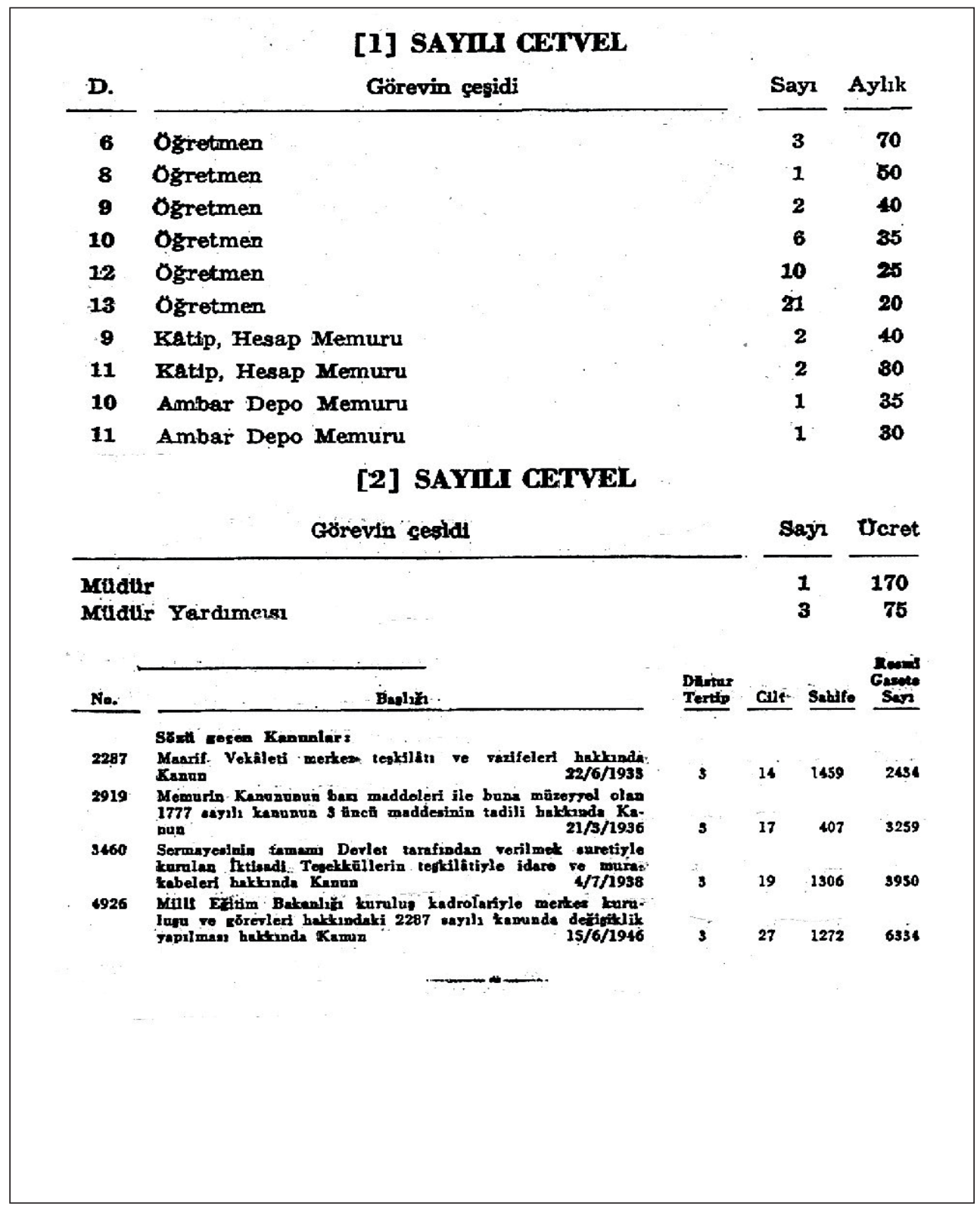


EK 10

\section{Zonguldak Milletvekili Sabri Koçer'in Maden Teknisyen Okulu mezunlarına doğrudan} mühendis unvanının verilmesi konusundaki sözlü soru önergesi ve konuşması

(T.B.M.M. Tutanak Dergisi, Dönem VIII/Cilt 20, 305 - 306).

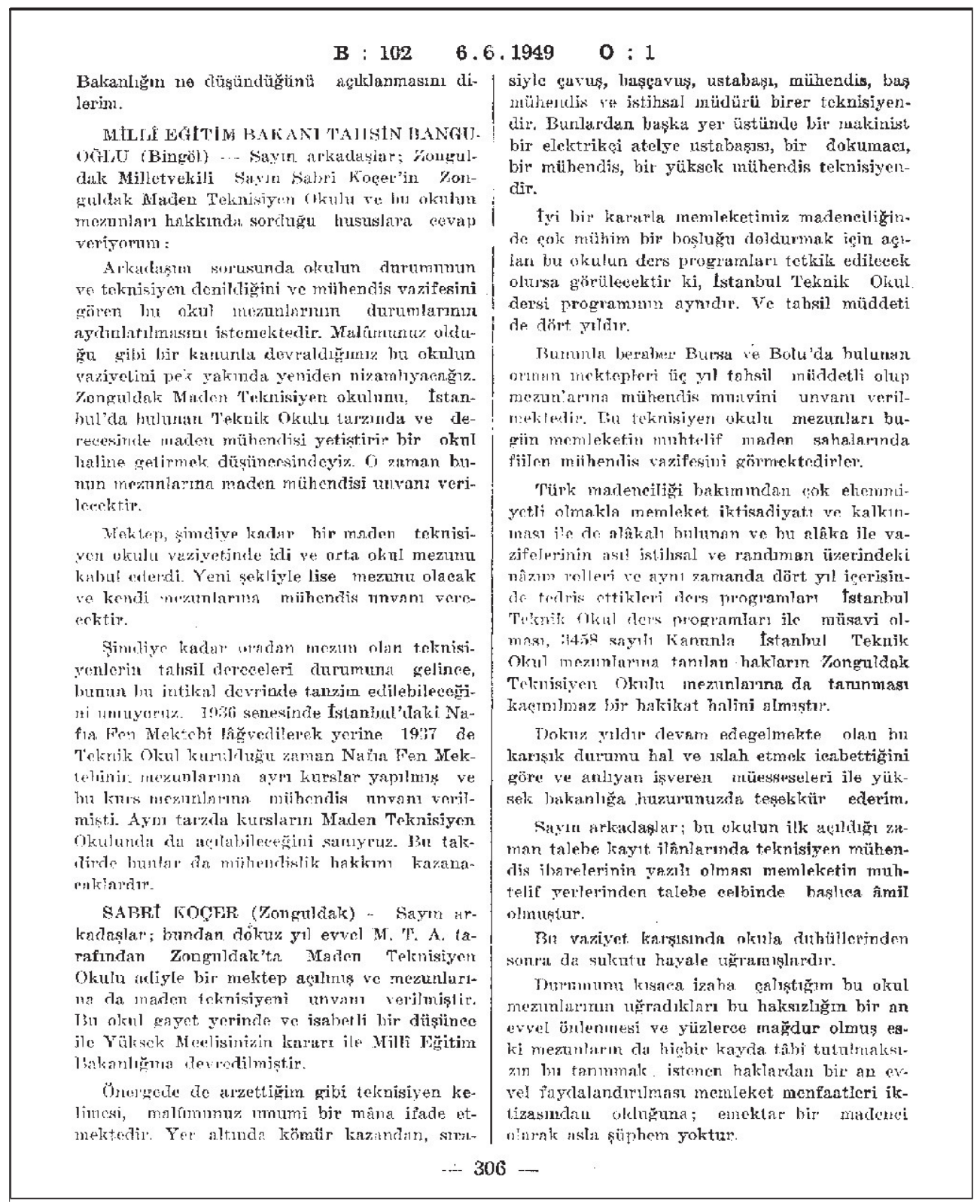




\title{
T. B. M. M.
}

\section{TUTANAK DERGISI}

\author{
Yüz ikinci Birleşim
}

6.VI.1949 Pazartesi

9. - Zonguldak Milletvekili Subri Koģer'in. Zonguldak Ifaden Treknisizen Okidu mezunlark

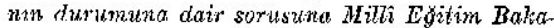
n 'Tahsin Zanguoğlu'nun sözlï cevabr (6/348)

Büyük Millet Meelisi Yüksek Bagkanlığ́ma

5284 sayılı Kanunla Millî Foğitim Bakan]।grma geeen Zonguldals Maden T'eknisiyen Okulu mezunln"1 liakkinda asağğlaki sorulara Rakanlığ̀n sözlü olarak eevap vermosini rica cderim.

7onguldak Millctyckili

Sabri Koger

1. Zonguldak Maden Okulunn programmda Mäicendis Okultunum dersieri tedris edildiọ̆i halde mozuntarmn tekmisiyen unvanı verilmektedir. T'oknisiyen kelimesi umumi bir mâna ifade etiligrino ve madenoilik lisanunda da yer altun. (Ia kömür kazandan sirasiylo hușmühendise kadar teknisị̣on donildiğine göre mühendis vazilesini gören bu oktil mexunlarmun karışlk olan durumlomnin aydinlatilmasi.

2. Bu oktul mezunlar lijlen mïhendis vazifesi gördükleri gibi askerlik durumları bakmmdan da yedek subay hakknx haiz oldiłklarmdan ntïhendis unvanı verilip verilmivecĕ̆i hakkında

EK 10

(Devam) 
EK 11

Zonguldak Maden Teknik Okulu'ndaki kursu bitirip maden mühendisi diploması alan Maden Teknisyen Okulu mezunları

(Zonguldak Maden Teknik Okulu arşivi)

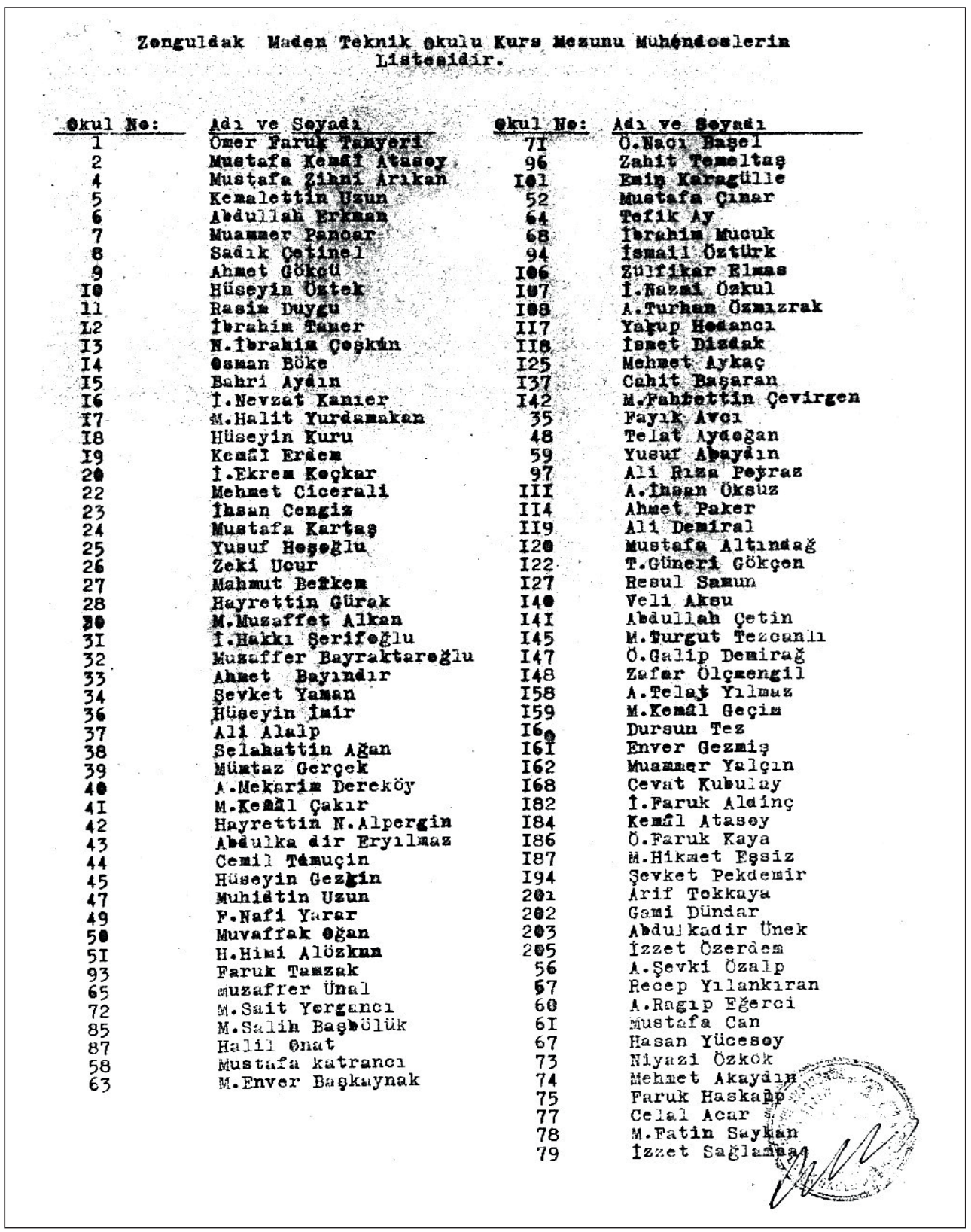


EK 11

(Devam)

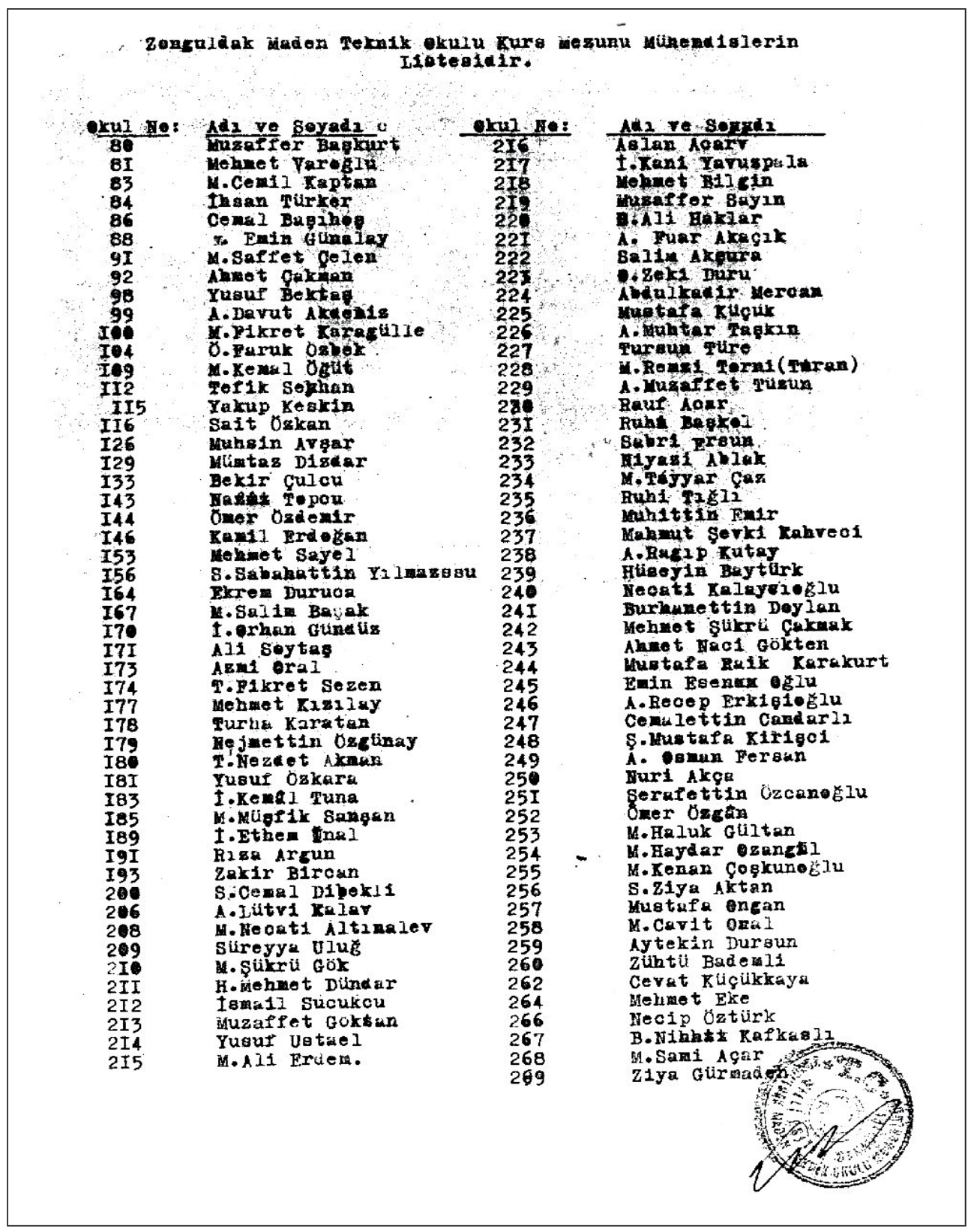


EK 11

(Devam)

Zonguldak Madon Telmik Okulu Kurs Mezunu Winendislerin Ifatesidif.

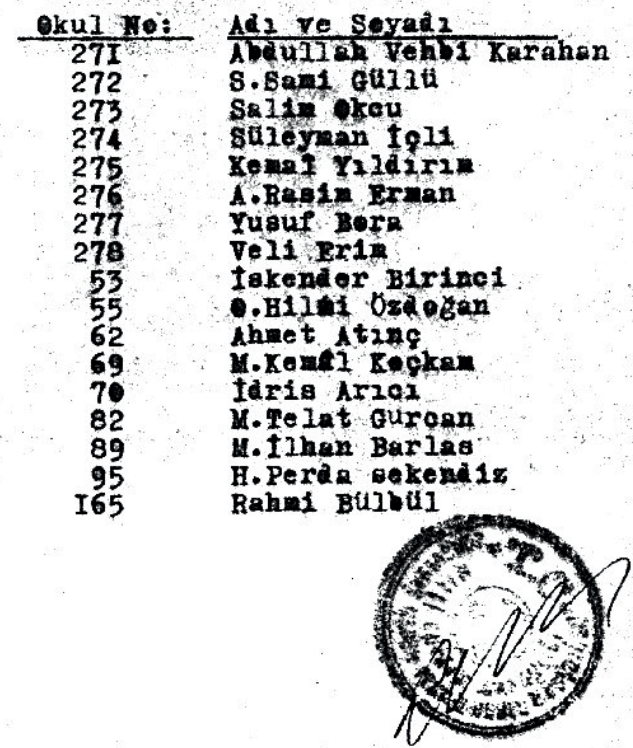


Açıklama: Bu makale 9 - 10 Kasım 2006 tarihleri arasında Zonguldak'ta yapılan ve “Dünden bugüne Zonguldak’ta madencilik eğitimi”" konulu "Zonguldak Yüksek Maadin ve Sanayi Mektebi Kongresi”nde sunulmuş olan “Zonguldak Maden Teknisyen Mektebi (1940 - 1949)" başlıklı bildirinin gözden geçirilerek genişletilmiş biçimidir. Kongrenin ardından bildiri kitabı basılamadan kalmıştır. Kongrede sunulan ve bir bölümünün orijinalleri yazarın özel koleksiyonunda bulunan görsel malzemenin etik dışı olarak kopyalandığ1 ve daha sonra ya hiçbir kaynak gösterilmeden veya yazarın adı yerine başka kişilerin adları verilerek, bir tanesi de Bülent Ecevit Üniversitesi’nin yayını olan çeşitli yayınlarda kullanıldığı görülmektedir. $\mathrm{Bu}$ durum karşısında, bildiri metnini yeniden gözden geçirip genişleterek orijinal görsel malzeme ile birlikte yayınlama zorunluluğu doğmuştur.

\footnotetext{
Hakem Değerlendirmesi: Dış bağımsız.

Çıkar Çatışması: Yazar çıkar çatışması bildirmemiştir.

Finansal Destek: Yazar bu çalışma için finansal destek almadığını beyan etmiştir.

Peer-review: Externally peer-reviewed.

Conflict of Interest: The author has no conflict of interest to declare.

Grant Support: The author declared that this study has received no financial support.
}

\section{KAYNAKÇA / BIBLIOGRAPHY}

\section{Arşiv Kaynakları / Archival Sources}

Emre Dölen Arşivi (İstanbul) $)^{38}$

Zonguldak Madencilik Okulları Arşivi (Zonguldak) ${ }^{39}$

Başbakanlık Cumhuriyet Arşivi (BCA): Fon kodu: 30.19.1.2/Yer No: 92.91.15; Fon kodu: 30.18.1.2/Yer No: 95.40 .6

\section{Basılı Kaynaklar / Printed Sources}

Acun, Niyazi. Toprakaltı Servetlerimiz - "Maden Tetkik ve Arama Enstitüsü” Çalışmaları. İstanbul: Sinan Basımevi 1947.

Açıkgöz, Bektaş ve Tuğrul Ünlü. “Zonguldak Yüksek Maadin ve Sanayi Mektebi Kongresi.” Madencilik Bülteni (Temmuz - Aralık 2007): 102 - 104.

Anıl, Mustafa Nuri ve Nejdet Merey. Türkiyede Maden Mevzuatı. 2 cilt. İstanbul: Tan Matbaas1, 1942.

Dölen, Emre. "Zonguldak Maden Mühendis Mekteb-i Âlisi (1924 - 1931).” Zonguldak Kent Tarihi 05 Bienali Bildiriler Kitabı içinde 21 - 31. Zonguldak: Zonguldak Kültür ve Eğitim Vakfı, 2006.

38 Metin içinde 'Yazarın arşivi' olarak belirtilmiştir.

39 Zonguldak'ta açılıp kapanan madencilik okullarının arşivleri birbirine devrederek Zonguldak Maden Teknik Okulu'na kadar gelmiş ve bu okulun da 1962 'de kapatılması üzerine bütün arşıvler ve kıymetli evrak Millî Eğitim Bakanlığı'nın onayı ile 15 Şubat 1963'de Zonguldak Erkek Sanat Enstitüsü Müdürlüğü’ne zimmetlenmiştir. Altmış yıla yakın bir süre burada korunan arşiv Zonguldak Maden Müzesi’nin açılması üzerine buraya aktarılmıştır. 
“Ereğli Havza-yı Fahmiyesi maden amelesinin hukukuna müteallik kanun.” Düstur, 3. Tertip, 2: 91

Erkek Teknik Öğretim. Ankara: Millî Eğitim Bakanlığı Yayınları, 1949.

Etibank: 1935 - 1945. Ankara: 1945.

Fenmen, Refik. “Zonguldak Yüksek Maadin ve Sanayi Mektebi.” İş 20, 159 (1954): 21 - 27.

Hasan, Ö. “Zonguldak Maden Teknik Arama Mektebinin Bugünkü Durumu.” İş 14, 77 (1948): 11 - 13.

İleri, Turgut. "Cumhuriyet Döneminde Açılan İlk madencilik Okulları ve Madenci Yetiştirme Kursları." International Journal of Social Sciences 5, 6 (2012): 251 - 262.

"Maden Teknisyen ve Başçavuş Okullarının Çalışmalarına Kısa Bir Bakış." Maden Tetkik ve Arama Dergisi 34 (1945): $307-316$.

Maden Tetkik ve Arama Enstitüsü 15 Yıllık Faaliyeti. Ankara: M.T.A. Neşriyatı, 1950.

Özer, Hasan ve Kamuran Karabalık. "Yükseköğretim Tarihi İçerisinde Zonguldak Maden Tatbikat (Başçavuş) Mektebi (1937 - 1940).” Yükseköğretim ve Bilim Dergisi 7, 2 (2017): 185 - 191.

Resmî Gazete, Say1 2411 (27 May1s 1933), 2508.

Resmî Gazete, Say1 3055 (22 Haziran 1935), 5378 - 5380.

Resmî Gazete, Say1 4623 (27 Eylül 1940), 14755 - 14756.

Tak, İsa. “Osmanlı döneminde Ereğli Kömür Madenleri’nde Faaliyet Gösteren Şirketler.” Atatürk Üniversitesi Türkiyat Araştırmaları Enstitüsü Dergisi 18 (2001): 253 - 257.

T.B.M.M. Tutanak Dergisi (Dönem VIII/Cilt 20), 305 - 306.

Yüksek Maadin ve Sanayi Mühendisi Mektebi Talebe Rehberi. İstanbul: T.C. İktisat Vekâleti, 1931.

Zaman, Ekrem Murat. Zonguldak Kömür Havzasının İki Yüzyılı. Ankara: TMMOB Maden Mühendisleri Odas1, 2004.

Zaman, Ekrem Murat. “Zonguldak Kömür Havzası'nda Madencilik Eğitimi ve Maden Mektebi.” Zonguldak Kent Tarihi 05 Bienali Bildiriler Kitabı içinde 33 - 49. Zonguldak: 2006.

Zaman, Ekrem Murat. Kömürün Çocukları. Ankara: Karina Kitap Yayınları, 2013.

[Zonguldak Halkevi], Zonguldak 923 - 938 Cümhuriyet'in XV. inci Yıldönümü Hatırast. İstanbul: Tan Matbaas1, 1938.

Zonguldak Sanayi ve Ticaret Odası. Cumhuriyetin On Yılında Zonguldak ve Maden Kömürü Havzası. 1933. 